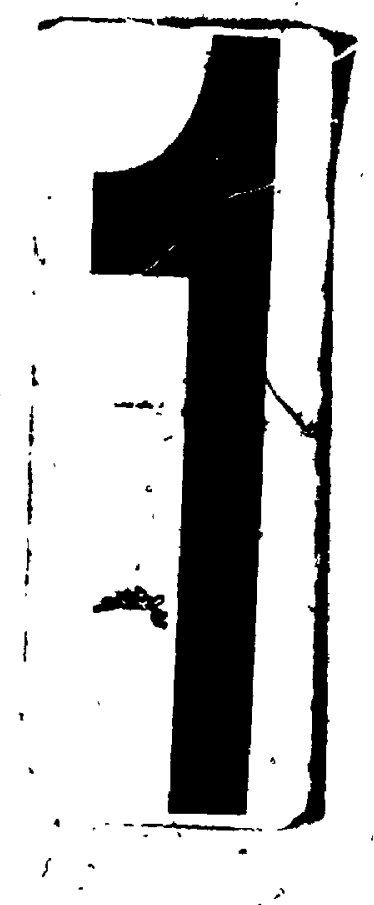


Canadian Theses Service Services des theses canadiennes

\section{Otlaws, Canada}

K1A ON4

\section{NOTICE}

The quality of this microfiche is heavily dependent upon the quality of the original thesis submitted for microfilming. Every effor has been made to ensure the highest quality of reproduc- . tion possible.

If pages are missing. conacl the university which granted the degree.

Some pages mat have indistinct print especially if the original pages were typed with a poor typewriter ribbon or if the university sent os an inferior photocopy.

Previously copyrighted materials "journal articles, published tests, etc.) are not fitmed.

Reproduction in full or in part of this film is governed by the Canadian Copyright Act, R.S.C. 1970 , c. C-30.

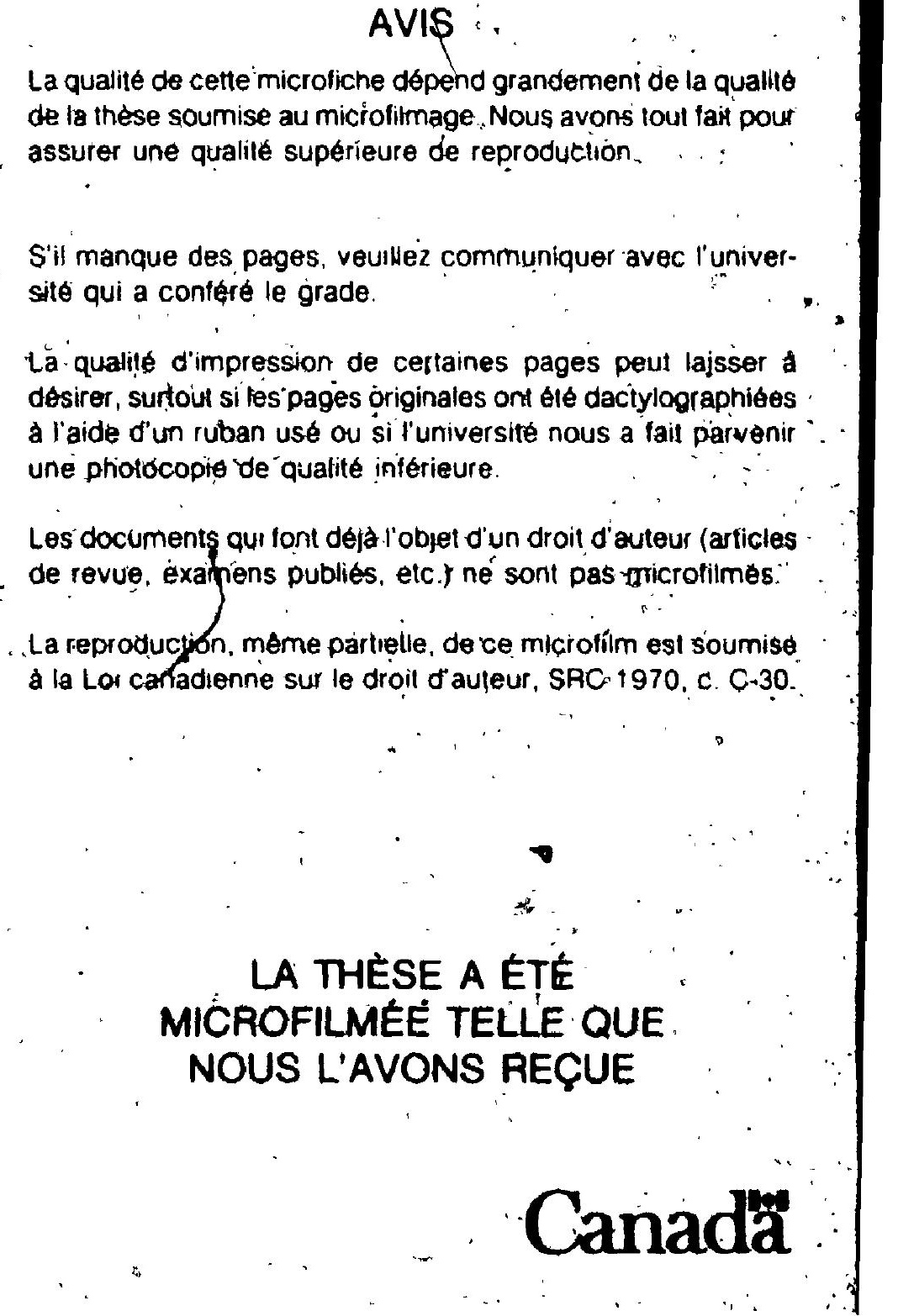




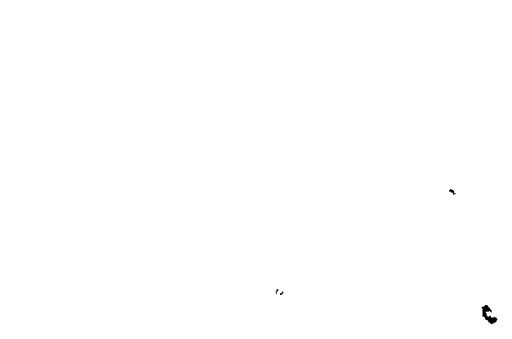

THE DYNAMICS OF TWO-PARTY POLITICS

IN JAMAICA: IMPLICATIONS FOR DEVELOPMENT

foy

JOAN, TAFEE, B.A.

A thesis submitted to

the Faculty of Graduate Studies and Research

- in partial rulfilment of

$\therefore$

fhe requirements for the desree of

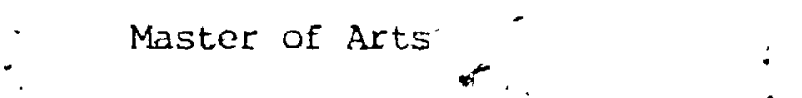

Norman Paterson Sciool of Intérnational AEraiós

Carleton University
ottawa, Ontario

25 September 1986

(C) copyright

1986, Joan Taffe

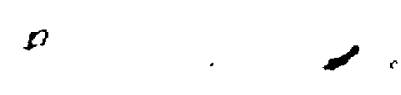


Permission has been granted to the National Library of Canada to microfilm this thesis and to lend or sell copies of the film.

The author (copyright owner) has reserved other putication rights, and neither the thesis nor extensive extracts Erom it may be printed or otherwise reproduced without his/her writen permission.
L'autorisation a ete accordée a la Bibliotheque nationale du Canada de microfilmer cette these et de preter ou de vendre des exemplaires du Eilm.

L'auteur (titulaire du droit d'auteur)" se reservé les autres droits de publication; ni Ia. these ni de longs extraits de celle-ci ne doivent etre imprimes ou autrement reproduits sans son autorisation ecrite. $\infty$ 
The undersigned hereby recommend to the faculty of Graduate Studies and Research acceptance of this thesis, submitted by Joan Taffe, in partial fulfilment of the requirements for the degree of Master of Arts.

2 


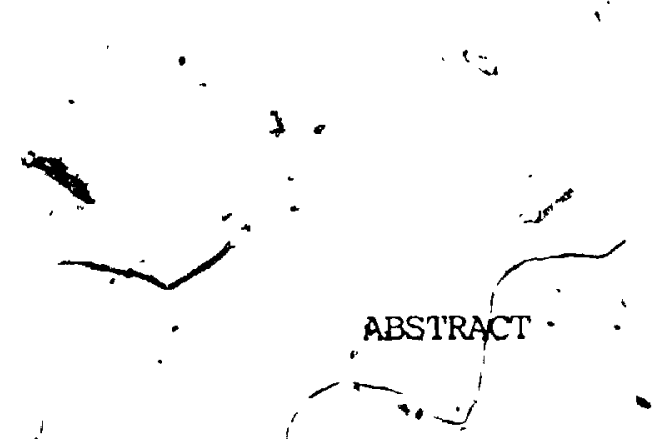

There is a tendency on the part of political development. analysts to regard the establishment of a woll-institutionalized system of competitive democratic polutics, as a pre-condition for national development in the Third World. USing Jamaica as one example of a developing country which has possessed a stable system of parliamentary democracy for more than four decades, it is possible. to. demonistrate that the existence of such institutions is not necessarily conducive to national development. . Furthermorc, it can be argued that in a developing country such as Jamaica, competitive. polizics could actually retard development, because of certain characteristics, inherent in multi-party politics, This study attemptis to establish the relationship between political parties and national development in Jamaica, in order to discover the contradictions which arisoobetween a well-functioning two-party system, and the actuilization of national development.

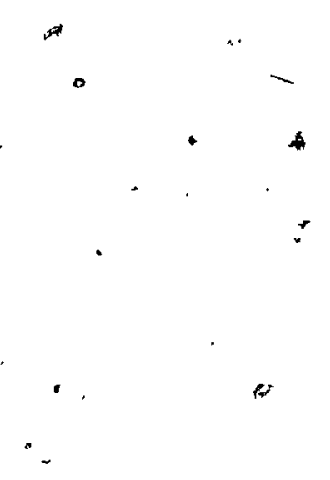


A. ACKNONLEDGEMENTS

1

. I wish to thank my Supervisor, Dr. Lyndon

E. McLaren, for bringing to this thesis thebenefit of his vast knowledge and experience in Jamaican party politics. I am also cxtremely grateful for the countless hours he so graciously and assiduously contributed to the task of supervision.

I atso owe a large debt of gratitude to my Advisor, Prof. Joseph Manyori, for his insightful comments and suggestions, as well as for his keen interest in the topic, which. sustained my energy and enthusiasm for this work for well over a year. $\because$ 
Abstract $\therefore \because \cdots \cdots$

$\ldots \ldots \ldots \ldots \ldots \ldots \ldots \ldots \ldots$

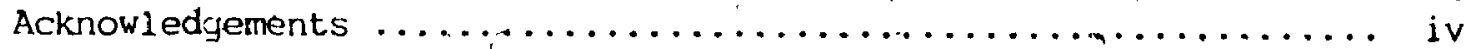

Table, of Contents $\ldots \ldots \ldots \ldots \ldots \ldots \ldots \ldots \ldots \ldots \ldots \ldots \ldots \ldots \ldots$

. List of Tables ............................. vii

INTRODUCTIONON Analytical Approach

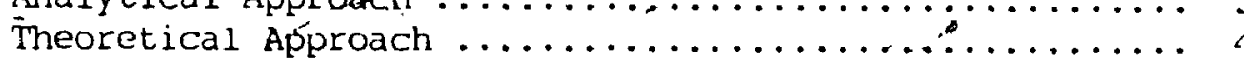

Referenceśs.

$\infty$

1.* CHARACTERISTICS OF POLITICAL PARTIES AND

IMPLICATIONS FOR JAMAICAN POLITICS $\ldots \ldots \ldots \ldots \ldots \ldots \ldots \ldots$

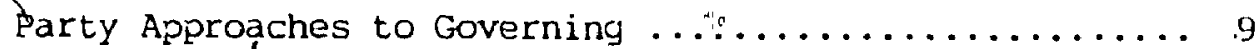

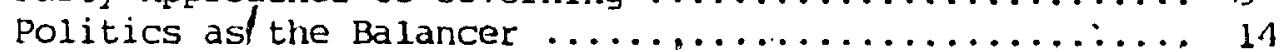

The Electorate and Rational Choice ............... 16

Party Politics and the Public Interest ........... 17

Policy Determination and Electoral Expediency ........ 18

Economic Development and Party Strategy ............ 21

References ............................. 23

II. POLITICAL PARTIES IN JAMAICA: BACKGROUND TO THE 1970 's ... 25

Socio-economic Class structure ................. 25

Economic and Sociąl Conditions ................ 28

The Structure of Government ............... 30

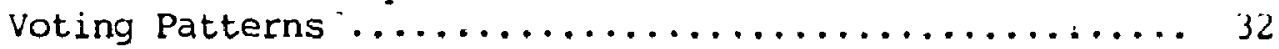

Origins of the Political Parties ............... 34

Origins of Party Ideologies $\ldots \ldots \ldots \ldots \ldots \ldots \ldots \ldots \ldots \ldots \ldots$

- Interest Groups and the Development of Party Power Basc. 38

Electioneering and the "Rational" Electorate ........4 41

Party Policies .......................... 43 .

Policy Implications for National Development ........ 46

References ............................. 50

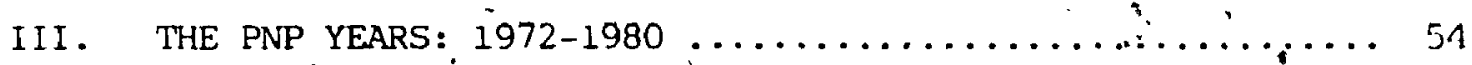

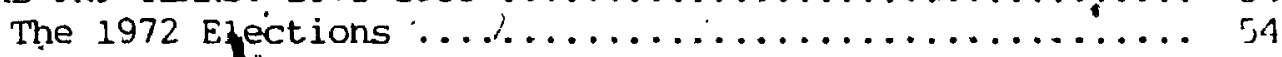

The Ideology of Democratic Socialism .............. 6i

Policy Implications ..................... 64

The 1976. Elections ....................... 67

Implications for Development ................. 73

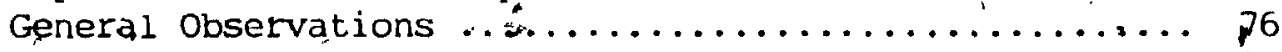

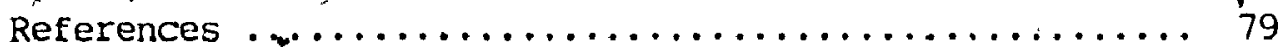

IV. THE JLP YEARS: $1980-1983 \ldots \ldots \ldots \ldots \ldots \ldots \ldots \ldots \ldots \ldots \ldots$

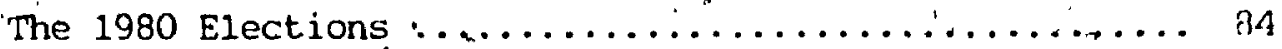

The. JLP's Ideological Tendencies $\ldots \ldots \ldots \ldots \ldots \ldots \ldots \ldots . \ldots . \ldots 9$

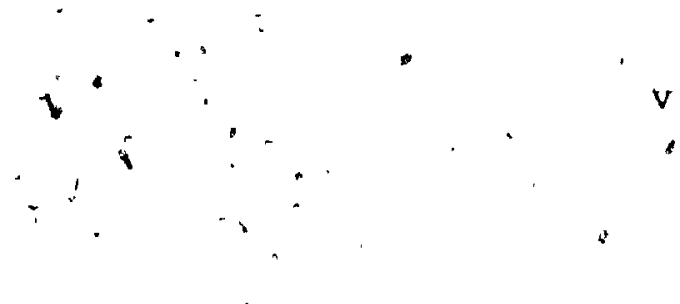




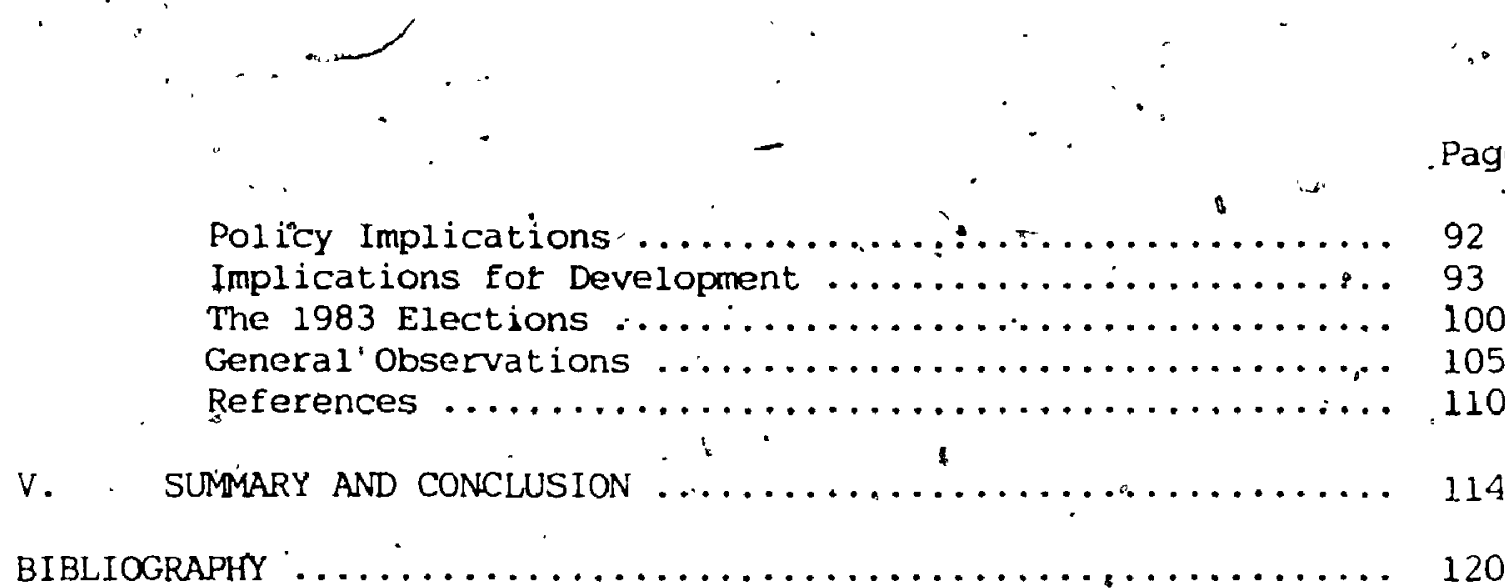

rate

6

Policy Implications $\ldots \ldots \ldots \ldots \ldots \ldots . \ldots \ldots \ldots \ldots \ldots . \ldots . \ldots 9$

Implications fof Development .................. 93

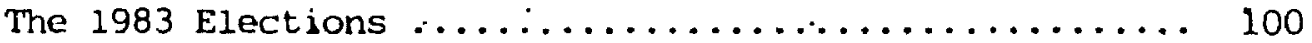

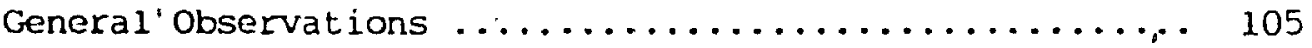

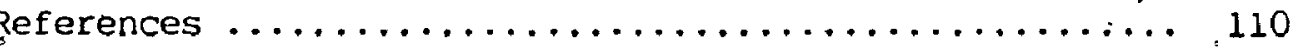

siv

$$
\checkmark
$$

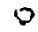

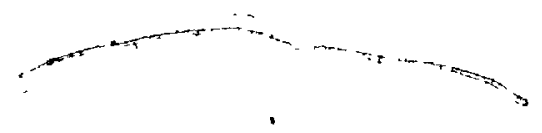

.$v i$ 

INTRODUCTION

For many Third World countries, the period following independence from colonial rule has been the most critical in charting the future courses of national development. The transfer of political sovereignty from colonial to independent status has in most cases meant the transfer of costs and responsibilities for rebuilding an effective sociąl system. - Inherited political institutions are of ten put to the test of coping with increasing domestic and external power contentions and conflicts of interest. In addition, stress arising from unfulfilled expectations often fuel even greater political opposition." "The balance of power in domestic politics often shifts in response to $\dot{a}$ variety of internal and external pressures; while political leaders try to consolidate power in circumstances of poor economies, limited policy capabilities and unstable alliances. "1

In view of the crucial role which politics plays in developing societies, it is understandable why mach of the literature on political development has sought to analyse the relationship between social, economic and political institutions from the standpoint of weak or unstable political structures. 2 This approach is often justified by the fact that government usually representt the largest organization in most . developing countries, and is based on the premise that its sapacity to maintain and control large osganizations is the basis on which any "modern" society is built. ${ }^{3}$ Hence, the view that "effective political. organization is the most important task facing. Third world countries. today. " 4

The problem with this tendency to focus analysis on the 


\section{$ه$}

development of institutional structures ${ }^{*}$ ge gornment is that it ignores the small number of developing countries where parliamentury and competitive party politics continue to flourish under social environments not qualitatively different from those where governmental institutions have either collapsed or, been modified beyond recognition.

In depicting the relationship between democratic institutions \& and economic dévelopment, Lucian Pye has, stated, 6

the goal of economic development dan be better realized if the Eunctional requirements of the political system are met by participation in competitive poiltics.

In Jamaica, the "functional requirements" of the political system are indeed being met by an extremely active mass participation in competitive democratic politics since 1944, and has continued to do so since independence in 1962. However, political development analysis fális to explain why this system has so far been unable to produce the projected

1 results of economic and sociăl development.

The purpose of this thesis, therefore; is to examine the role of politics in Jamaica and its implications for national development, in an effort to gain some insight into this contradictory assumption.

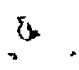

Analytical Approach

One must admit that any attempt to analyse the 1mpact of politics on national development, in the broadest terms is a rather ambitious undertaking. It is necessary, therefore, to limit the scope of the analysis to, a) the most relevant context within which the politics of parliamentary democracy can be viewed, and b) the variable in national development which affects political partes and their policies most. I 
I have therefore identified political parties as the central focus from which to view their approach to national development. As in mogt
countries the state of the economy is generaliy the most important policy issue facing governments, an examination of government policies will tend to reflect the political implications for the general" economy .

Events in Jamaica since 1972 have made the, study of political parties a particularly interesting one in which to view their impact on national development. There arê two reasons for this. First, since the early part of the 1970's, Jamaica has experienced the growth of strong party identification with two divergent ideological approaches to development by the two leading party contenders for government the Jamaica Labour Party (JLP) and the Peoples National Party (FNP). The term "ideology" is taken in its broadest sense to reflect "a system of ideas that seeks to explain, justify and motivate leaders $\rightarrow$ in a particular poicy." 7

Secondly, the Jamaican economy has steadily declined during this same period. Between 1972 and 1980, the PNP developed what it called a "democratic-socialist" approach to development under the leadership of the then Prime Minister Michael Manley. Since 1980, The JLP, led by Prime Minister Edward Seaga, has assumed the reins of government with ad decided leaning toward a more "capital ist" approach to development. " Although ideological label" attributed to either. party can be somewhat misleading, the parties have pursued divergent domestic and foreign efonomic policies, which indicated certain tendencies that may be conceptualized within these general ideological modes. A comparison of these two approaçhes and their policy implic- 
ations, will produce some insight into the relationship between politics. and development in Jamaica in recent years.

\section{Theoretical Approach}

Although one might not subscribe completely to J. Schumpeter's definition of democracy as "an institutional arrangement in.which . aiternative governments, competing elites, offer themselves for selectiun

- by an electorate whose sole political function is to choose, lock, stock and barrel, one of these teams every few years, " 9 one must acknowledye that to talk about democracy today, is to talk about a systom of competing political parties. According to Carl Stone, 10

One of the basic principles of democratic theory is the notion that competitive political parties offer alternate approaches and emphases in the formulation and execution of public policy. The precise nature of policy differences between party governments in two-party or multi-party. systems is therefore an important area. of enquiry in establishing, the relationship between democratic theory and the actual practices of party government, under conditions of electoral competition- such as have been shown to exist in the Jamaican political system.

As the nature of policy differences between the two major partics is reflected in their respective ideological approaches to developmentr it is therefore useful to first examine the nature of these ideological differences, wich, Christopher Chapham observes, "reflect the way in 'wich politicians seek to make sense of the position'they are in, us the options they face provide at least one guide to what they actually do." 11 The thesis will seek to meet it's theoretical objectives through a general analysis of the characteristics and functions. of competitive political partiẹ with particular relevance to the Jamaican two-party 
system. This theoretical framework will provide the scope for a closer examination of party approaches to development: from an ideological and policy perspective. It will also reflect the constraints two-party systems impose on long term development initiatives, as well as provide a basis, from which to judge the success or failure of party pulicies. Finally, in a thesis of this scope, it seems necessary to indicate not only what will be included, but also what will not. As s the study taises a rather comprehensive approach to political parties in relation to their ideological and policy influence on national development, it would be beyond its capacity to discuss in great detail 0 the Jamaican economy, which though central to the goals of national . development, would be more appropriate to a study of political economy. The role of the economy will, however, be treated within the theoretical confines of the political parties' approach to governing.

In addition, the term "development" will be put to frequent usigh in this study. But what exactly does one mean by, this term? As any scholar of Development is aware; the bounds of definition are virtually unlimited. It takes into account both normative and pragmatic (ideolajical and material) goals which a nation sets for itself, and has. led some scholars to devote' a substantial amount of effort to discerning. "new developments $i$ the proifific usage of the term depelopment. "12 nlthough no deíinitive explanation can sufficiently cover its meaning, some attempt will be made to limit the usage of the term to the contextual framework withion which it, is being discusşed. The Jamàican political system is basedion democratic principles, which imply that oryernment should be condufted according to what it believes to be inm "joest. interest" of thk majority of its citizens. In this context, therefore, 


\section{8}

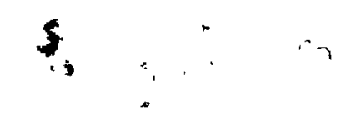

6

we are. concerned with development from the puint of vicw of what cach party perceives to be in the best incerest of the majurity, and how lixy convey these perceptions in the types of policies they pursude.

Finaly, a thesis of this nature produces a nutural terancen to question the viability of parliamentary denocracy in a developing. country such as Jamalca. This guestion is índeco vulid, but ayain, due, not conform to the functions of this study. Of course, the problems. inherent in this system, and thoir implications. for the country's welfare will be analysed. However, the primiry intent is to slook at. the politics of one country characterized by this system, and lo exumine the results. 
Introduction

' Car.1 Stone, Democracy and Clientelism in Jamaica, London: Transaction Books, 1980, p. 71 .

2 sce Lucian Pye. Aspects of Political Development, Boston: Little Brown, 1966, or Samuel Huntington, Political Order in Changing Societies, New llaven, Conn: Yale University Press, 1968, or G.A. Almond and G.B. Powel1, Compurative Politics: A Developmental Approach, Boston: Little Brown, 1966 .

3. Christopher Clapham, Third World'Politics, London: Croom Helm, - 1985, p. 5.

4 David E. Sclumitt, Dynamics of the Third World, Cambridge, Mass: Winthrop, 1974, p'is.

\section{$+$}

5 Carl Stone, "Class and the Institutionalization of Two-party Politics in famaica," Journal. of Commonwealth and Comparaeive pofitics.

6 Pye, 1966, p. 73:

7 Schmitt, 1974, p. 18..

8- the ideologicai tendencies of both parties will be elaborated upon in the following chapters.

9 'J. Sichumpter, Cajitalism, Sociélism und Democracy; New York: Harper and Row, 1950, cited in David Robertson's A Theory of Party

- Competition, London: John Wiley \& Sons, 1976, p. $\overline{1}$

10. Stone, $1980 ;$ p. 225 .

11 Clapham, 1985, p. 44 .

12 C.A.O. Van Nieuweiluije, Development Bëqins at Home, Toronto: Pergamon Préss, 1982, pp. 1-64. 
CHAPTER' I

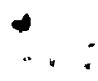

CHARACTERISTICS 'OF POLITICAL PARTIES

AND IMPLICATIONS FOR. JANAICAN POLITICS

This study is primarily concerned with how competitive polilical

parties ppproach the rolo of jovernment and the problems they encuunear whthin a democratic parfiamentary systom in scokiny to put into ceroce

divergent views on pubiic policy. According to prory leisersun', the essential reason for engaging in politics is to try to put purtirulur "views on public policy into effect by "controlling the administration." While it is true that a party virtually 'controls both the Leyishative. and Executive bodies while in of icc, ' its ability to runction crectively, and indeed to maintain contropl long enough for its policies to effective, is often limited by the political principles which brought tine party to office' in the first place.' According to David Robertsun,"

"A party which is committed to, and organized for. competitive electural politics must accept the following two basic principles:"

1) that the office is to won or lost, inside a system, as a result of its clectoral dicraction, over and over again, "and

2) that to win an clection is, only to have the right to govern for a limited period, with tine high probability, and not just the distant probability, oi losing the. subsequent election.

Hence, electoral party systems hinge on the expectation of $f^{\text {n allorration }}$ of government. 4' ' characteristic of competitive democratic politic. of government. This characteristic of competitive democratic politics profoundly, influcrices the approaches political parties take to governing.
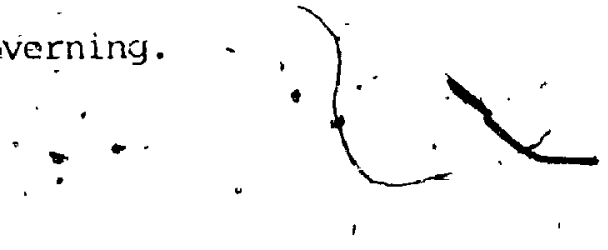
Party Approaches to Governing

Political analysts generally identify. two separate approaches to governing that a party might take. Although tipese are conceptualized" in differentoways, there is a başic similarity of views centered on the . ideological and pragmatic paths. In reviewing the varidus assumptions made by analysts, it is possible to discern some relevance to party approaches to göverning in Jamaica.

In Robertson's view, ${ }^{5}$ governing can be seen as.eitiner an "architectonic" activity, which involves the building of an entire new social reality, or as a "pragmatic" activity, which invalves problem solving within the status quo on a gradual and incremental basis along non-contentious grounds. He argues that a competitive párty has to accept the latter, because two roughly balanced parties, each committed to a radically different approach . chot survive, because once an architectonic party has won affice and started to implement its design, democracy can only bet assured if the opponents are prepared to accept the new version. If they are not, and win the subsequent election, and repeal' major legislation, the stresses are too high to sustain alternating governments. Indeed, the government can hardly - accept the legitimacy of its own defeat if it. is to be replaced by one that will dismantle all it has done.. He therefore concludes, "that even' if revolution does not follow, alternating erection and repeal of major. social institutions is not a process that can be regarded as an effective way of making social decisions.

This has a great many implications for Jamaica"'s two-party system, and will be more closely examined in later chapters. At thịs. point, however, it might'be worth noting that Jamaica does indeed 
possess tyo well balanced pàrties, which are comitted to radically different policy perspectives. Whether or not one can argue in absolute terms,about the nature of cither party as "architectonic" or "pracmatic" in their apprdaches to governing is another matter. In the caso of the PNP, which held office for two consecutive terms from 1972 to 1980 , the characteristics of the architectonic approach to governing are fairly evident in its, jideological tendencies and policy commitments to a new - form or egalitarian society, envisionod through its idcoluyy of democratic socialism. The JLP; which 'was elected to joveris in $1980^{\circ}$ -and again in 1983; bears some çharacteristics of the architcitonic model, evidenced by its extrome commitment, to a western capitalist modol of "development. In sevoral other respects, howevir, the party cun be regarded as'pragmatic, not only by its etonservative "market díriven" policies, but also by its technocratic approach to the business of governing.

- Perhaps from a liberal Western. peispective, the PNP might be more readily idantified as having, a democratic-socialist. tendency, with, for exampie, a more centralized and redistributive policy approuch. The JLP might be regarded as having a more liberal capitalist approuch, with a. free enterprise "market" orientation, for example, combined with . individualistic tendencles as opposed to socialist co-operative iendencies. One must be extremely careful to qualify, such icloological labels, ".." however, as the context within which'these, are viewed externaliy cannit. be reliably substituted in the Jamaican context. It is worth noting that both parties also subscribe to the idcological notions of nationalisio and democracy. There are a great many factors which influence purty tendencies, that cannof be explained by theories which develop out of 


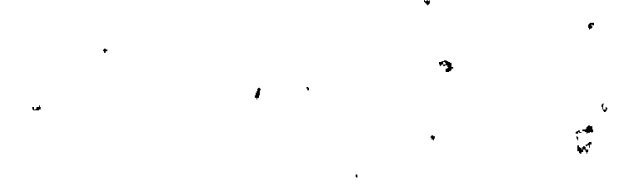

$=\quad \therefore$

* vastly different European or Anglo-American inistorical experiences.

$\$$

One assumptionat can be agreed upon, is that the two parties do take radicaliy diffecent approaches to governing which produce disruptive results in the development process when jovernments alternafe. Indeed, since 1972; the alternation of governments has produced the dismantling of scveral important social and economic policies when one or the other party came to power. From 1972, the PNP. moved towara centralized control of many industries and introduced several new: social reforms, but by, 1980 when the JLP took of ice, it reversed unmost all of these policies. Such policy inconsistency has served to confuse and disruit the planning and implementation of long-term development goals, which are fundamental to, national development. This inconsistency does not necessarily reflect the worti of the policies as their resuits are often affected by other unprodictablo internal and external factors. "However, it, is the oft" utilizcd option * to. change governments if long-term policies do not, produce short-term : results, that has taken the toll on national develogment." In brief. Jamaican politics over the past fifteen years reflect a "start-allover", syndrome, in which policies are dismäntled and new ones begun. (or old ones reinstitjuted) as parties aliternate governments.

Robertson does offer some hope for the survival of competitive. democracies in casès where entire programs are implemented aftar the election of a party (for example, the creation. of the British welfare. state between 1945, and 1954, or the "Now Deal" during the Roosevelt years.) However, these occur successfully only when the new initiativel are fairly well accepted, by all major parties, or after an electoral result so decisive that opponents of the government realize they cannot 
win again unless they accept the new paradigms. 6

: Somehow, competitive democracy has managed not only' to survive in Jamaica, but flourish, in spite of itos inability to mest these iwo conditions. This will be explained later on in the chaptef when poicy - determination is analyscd in relation to issuces of political expedicncy. The problems faced by most developing countries - massin unemployment, illiterarcy, rapid urbanizatiön e etc. - intensify demands for immediate resulits. Honce the notion that only drastic transfunation of the domestic socio-economic structure can create the successful development has become, increasingly prominent im political thinking. However, the difficulty of overeming powgerul constraintsi, such as massive foreign debts in a small econom limits the results that can reasonably bc expected from the policy-maling syistems? Although most developing countries havẹ attompted to "idopt complex. and far-reaching forms of planning desiyned to reach a sist of pre-. determined goals; plans of ten impeded by all softs of unpredictuble. events: For example, unplänned decisions, unanticiputed çvents such as hurricanes, and others, that cannot be controlled, such as. the oil crisis, global inflation, or tack of skills to imploment the plans itsęlf.

The alternative offered by some anarysts of political developmeft ${ }^{8}$ is the" "incrémental" approach to decision-making. Their notions of gradual and limited decisions, slowly building on previous successes seom to be a sensibre and pragmatic response to uncertainty, imperfect knowledge and limited resources. However, this approach to governing. demands " $q$ ' high "level of rationality on the part of the political parties and the electorate. Unfortunately, where conditions demand immediate 
response and the 1 ife of a government is determined by, results obtained within a limited number of years, rationality is of ten the most difficult target to achieve.

In his analyșis poiltical parties, Joseph La Palombara ${ }^{9}$ takes into account the implication of frequently charging governments in respect to party approach to governing. He offers a fourfold class-: ification of competitive politics based in part on internal characteristics of the party and in part on the way political power is held. The latter refers to the political system, and the terms used to . describe them are "turnover" and "hegemonic." A hegemonic system is one in which over an extended period of time the same party holds government powex. Turnover situations are those which, even whën there may have boen hegemonic periods, there is relatively frequent change in the party that governs.

The second dimension along which he classifies competitive-systems is "ideological gpagmatic". These characteristics rdfer to the parties " ". themselves, and are useful in judging them in terms of where they fail in this continuum. From these two characteristiçs four subcategories. are conceivablé: a) hegemonic-ideologícal; b) hegemonic-pragmatic;

a. c)-turnover-ideological, and d) turnover-pragmatic. The configurations of turnover-ideological and turnover-pragmatic are most, useful in the context of Jamaican party politics.

According to La Palombara's analysis, where the central characteristic of the parties is ideological and there is frequent turnọver, one may expect a great deal of turmoil. Such situations "suggest that the society is.so evenly divided along two or more ideological lines that frequent turnover on the one hand makes it 
impossible for any one group to implement it's policies, and, on the other hand, assures that the succeeding group in pawer will seek to undo whatever may have gone before. Pragma'tic parties will tend to move more slowly when they are hegemonic and more rapidly when exposed - to frecuient turnover.

- Since. 1944, both Jamaican parties have alternated guvernment control every two terms, hence they can be viewed as turnover in character. From 1944, up until 19697 (five yoars aftẹr independenco), both parties ténded to follow a more pragmatic approach to governing, during which time the économy reflected a. slow but yradual improvinent. However, it must be remembered that external forces coupled with a consensual drive for national independence made the period prior to. :1972 more conducive to this approach. Af́ter 1967, howcver, issues pertaining to.social equity and the distribution of wealth and resourcos, precipitated a change from the more pragmatic approach to a morc polairized approach to ideology and policy-making. The PNP's introduction of democratic-socialism as a new strategy for national development after 1972, was met with an extremely hostile raction from the pro-capitalist JLP oppsition. Hence, two conflicting development -strategies emorged why ho created the radical differcnce in both partics'. approach to jovernifg. It is the extreme differences in ideolojical und policy ápproache which enable one to attribute the characteristic or turnover-ideofogical to botil parties over the past fifteen years. Politics as the Balanincer

- According to Robert Rothstein, "apart from the external. influences, the factor most likely to affect the success or failure 
of development initiatives if the vision and comitment of the :" - political elites." 10 Political leaders must realize that they are: responsible for more than their own survival. They must also refrain from deluding themselves into believing that there are magical methods by which the problams of the present can be cquickly overcome. This means they must have" a proper sense of what needs to be done and attempt to "balance", the costs and benefits. Solving problems;

$\oplus^{\text {C Robertson adds, }} 11$
inhabits an illusive terrain somewhere between
"illusion and objective reality. They must be defined in terms of human values and expect- ations and equally they owe their existence to both real conditions and human perceptions - . A problem exists where some aspea of reality is not fitting our values or desires and where we either expect there to be a fit or believe that. it is both possible and proper to change the world and make it accord. with

$\because \quad \quad$ our desires. Objective reality must be there!

These two views express the need for a bakance between

- normative desires and objective realities. This, according to

A.H. Somjee, ${ }^{12}$ is.where the political process plays its most important role as balancer. He says, "what is needed is a continually readjusted . Whalance between ever renewing normative commitments and ever exploring "pfacticis ways of tránslating them into political reality."

One of the instances, where competitive politics can go wrong is, when a problem exists where conditions do not fit desires, and where governing. is seen' as satisfying demands. Politics then becomes a distributive activity in which questions are raised about whose demands get satiffyed and how the national pie or the "stream of ut1lity flowing from the government is distributed." 13 Mistaken beliefs -about how to solve problems on the port of politicians could lead to a: 
party suggesting to the electorate that it.could romove some inconvenience of life when it could not. This is relative to the Jamaican condition, particularly throughout the Mantey adminiștration, when normative desires for social equality resulted in seword fodistributive policies which the objective, realities "were unuble to mect. Such situations indicate the essential difference between what is

$*$ plausible and what is possible: ${ }^{15}$ creating a better appreciaion in

- the minds of the electorate what is realistically possible is onc of the major problems isherent in a highly competitive political sy'stem.

The Electorate and Rational Choice

Some analysts view the electorate as being too ignurint, or policies and too pré-disposed to party loyalties to enable them to discern rational objectives and make rational choices from the varicd "solutions to problems" offered them by competing parties. 16 partics usually attempt to conceptualize goals for the future and prescribe .programs for achieving them through vague ideologicalformulas. Anthony Downs 17 sees a justification for this strategy in the "cost to voters. of having precise information on poilicy stands." Wiercu's detailed -information on policy is difficult to come by and unreliable, a rough picture of what the party stands for, and a long-term attachment to the party on the basis of the similaxity between the 'voters' own ideology and the party's serves, instead. 18

one important point which Butler and Stokes ${ }^{19}$ raise, however! concerns how electorate attitudes towards issues are cormed in the

if Eirst place. As most electors have partisan dispositions, and the parties - themselves offer a lead on most issues, it is likely that the party will 

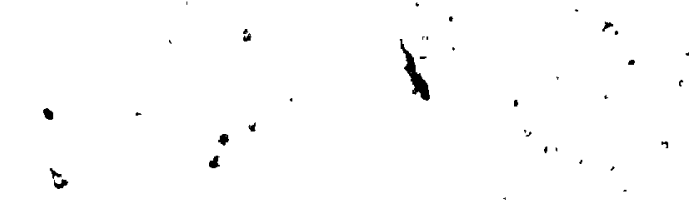

issume a spẹcial status in giving structure'to voter attitudes. When they do, the flow of cause and efrect is not from issue to party preference, but the other way around, from party preference to belief in the issue.

In a poitical systoh such as Jamaica's, with a strong. inclination towards partisan political loyalties, the electorate does tend to. embrace ideological labels or symuls on the strength of their identification with a party. This does not, however, prevent the development of ideolojical tendancies based on concrete issues which have been debated in the public arena. "Real issues, such as the role of the prlvate sector in the society or government acquisition of private ecohomic interests and how they should be acquired; are all central" to the "ideological contentions between parties and the policies they imply.".

\section{Party Politics and the Public Interest}

One of the assumptions of democracy is that the government ought to work in the public interest. Certainily "the gaals of any healthy. dethocracy are to find ways to provide the general population with freedom from hunger, ignorance, disease and so on, as well as offering them a sense of place and purpose through actual participation in political decision-making ${ }^{n+1}$ However, $\cdot$ in a society factionalized by class, as in Jamaica, it can be extremely difficult to put together a set of policies which appeal to a majority of interests and do not contradict each-other.

The social basis of parties and party loyalty pose one of the greatest dilemas to the democratic process. A political party 

democrucy is one in which the government automatically puts'into oproralion those policies that please a majority of the electorate." 24 0 This suggests that parties must determine policies cntirel on the trats of electarul expediency. Such an approach to policy doharmination could have grave consequences for developing colfutrics where the success of development policies raguires long-terh plannini, personul werifice and far-sightedness on the part of ity catizons. Il is of course desirable for partics to. encourage a more subtle and [lexible relationship between electoral popularity afid policy, but this is exdedingly difficult to stipulate in circumstghees where sưcesis at the polls depend on the party's response tof policies which demand almost immediate results.

In more developed countries, elgtoral expediency may sometimes bo sacrificed for sound policies, becaupe they may actualiy work in favour of the party. This usually agpends on the party's past record in office if formar policies proved successful despite initial upposition. 25 . In developing coptrtries like Jamaica, howevegr, party idcritification with sound pofrey records are highly improbable. This is partially because of the short-term electoral mandate and the problem of lony-term planning, fhen demands are immediate, and partially wecause of unipredictable expernal or internal pressures which often foil even the best of poljty intentions.

On the other hand, partly because of the popularity of some of its policics, and partly because of the appaling record of its opponents a party might be a tremendously strong candidate to win an election. In this instance, the minority interests of some groups of loyal. party supporters may be served, despite their general unpopularity, because 
the veters fecl they canbot risi the opponent, and are forecd to accept the minority interest policies as part of the baryin. Robarbin refers to this type of party strategy as a form or "policy blackmuil:" $26^{\circ}$ In 1972, the PNP canne to office with what was thon called "the most massive lancislide victory in the history of the country." 1 "1 1980 ,

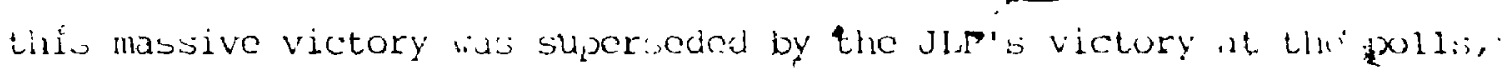

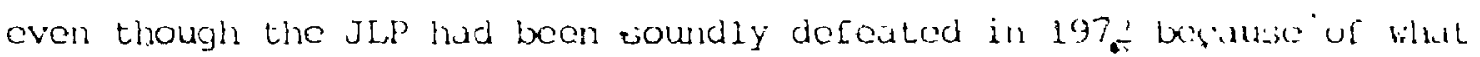
the electorate percelved to be a corrupt yoverdment bitich served snly

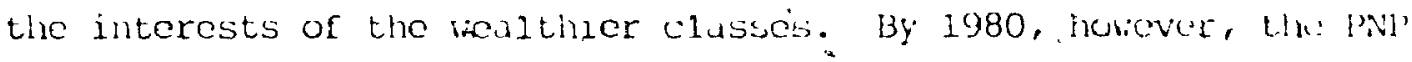
government had failed to achieve its poldcy gouls and the countiry, for a variety of reasons, suffered tremendous economic and sucinl setbacks. In 1980, the JLP was returned to office, wilh virtully. the same policy goals it had prior to 1972, mainly beciulso une cloctorate could nut "risk" another PNP government. Although the normative. commitment of the PNP to social justice and equituble distribution of wealth is still a popular ideology of the massos, they percoived the JLP to have better prospects for achieving short-term coonumile ifrowti, partiy because of the benefits voters expected rrom its closo ditalianco witir the United States policies; and partly beculuse some economi 4 growth had occurred during the more prosporous decade of the 1960': whon that party held office. The element of "policy ulackmuli" ipems

- evident as the underlying problems of social cquity and a redistribution of wealth, which concern the majority of the voting public, have been neglected, while the massive economic problems faced by the porsu: $\dot{r}$ : majority persist. 
$\therefore$

- Ecunomic Development and Party Strategy

According to Gabriel Almond, 27 "the relationship between

cconomic development and political competitiveness is an essertial attri-

bute of democracy," A number of stud have shown that there is a positive correlation between economic conditions and voter preferences. ${ }^{28}$

v.o. Key's study of political prossure groups indicated that "one of

the most popular causes associated with massive sinifts in party support;

yroup sentiments and opinions, and widespread convictions and beliefs, is attributed to changes in general business conditions, employment or prospurity." 29 . It is impörtant, therefore, to investigate the relationship between measungs of ectnomic success and policy position: Which parties react how. to what sort of economic conditions is a question of very jeneral interest, and the answer provides vital knowledge in sceking insights into competitive party atrategy.

The major accepted proposition is that voters tend to support the party or incumbent candidate in prosperous times, and to vote against them in periods of declining business. 30 Whenever something goes wrong witl the econimy, the government in power is liable to he held responsible, and may lose votes. According to Robertson, 31 "an economic disaster has one objective nature to any individual - bad. But for competing political parties, an cconomic disaster has two different strategic natures. For. 'the incumbent it is both objectively' and stratiegically bad, for the opposi: ition it can be strategically begeficial.:"

Inflation in the 1970 's was 'bad' for the PNP government, . but' good for the JLP opposition platform in 1980. But, what of the fact that the JLP incumbent lost the 1972 elections by a wide margin, when the economy was stili relatively strong?. And how is it that the PNP was 


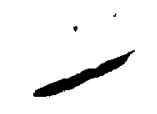

returned to." office in 1976 with an, overwhelming victory, 'during one of the worst periods of economic dectine in the nution's hislury? These questions will be answered' when the actual events ledilky up to the elections are examined in later chapters. For the moment however, it may be observed that theoretical. assumptiuns may, provide, a useful. anlerat to the voter response to cconomic conditions, but lhey cunnot be tuken as absolute. Asj leiserson stated, "such generaliculions aro subjeci to an fall things being equal qualification'." 32 Factors such as a louder's personality, strong ideological loyalty or forcian policy - purt unlarly. in crisis situations, sometimes produce roalignments. " ' Once elected, the management of the economy becumes onk of the greatest problems racing a Third.torld goverimeint. This problem is of cen stated in terms of "strategies for economic development," and those strạtegies often imply either a "socialist" (distribution orionted), or a "capitalist" (production oriented), Jpath to development. "Ihe ention a government choses has a sighificant impact on the well-beimg of all citizens. However, these choices lave had to bo made, not only within the context of an international conomic systẹm, which imposios constraints of a broady familiar kind, but cqually within the context, of the state structure itself.

Ceneral to the analysis of political parties are the steatejico which comptitive partićs employ, not only to obtain the powter la govern, buif to keep it. "Analysis indicates that the ideologicul pors-". pective of the party, and the policies they inform, nave a great crual to do with how they govern and the result they are likely to achicve. These characteristics of the political parties should fdevitate a ". closer analysis of their imp̈lications for party politics in Jamaica. 
1 Avery Leiserson, Parties and Politics, New Yórk: AlEred A. knopf, 1958 , p. 123.

2 Maurlce Duverger, Political Parties: Their Organization and. Activity in the Modern State, Translated by Barbara and Robort North, 3rd ed.'London: Metheun, 1967, pp. 394-95.

3 David Robertison, A Theory of Party Competition, London: John Wiley and Sons, 1976, p. 3.

9 Giovanni Sartori, Parties and Party Systems, Vol. I, London: Cambridge University Press, p. 192.

5 Rob̧ertson, 1976, pp. 3-4:

6 Ibid. p. 4.

7 Robert L. Rothstein, "politics and Policy-making in the Third world: Does a Reform Strategy Make Sense?" World Development; Vol. 4, No.8." 1976; pp. 699-700.

8 see R.S. Milne, "Decision-making in Developing Countries," Journal of Comparative Administration, Vol: 3, No. 4, Feb. 1972, p. 394. also see David Robertson, 1976, pp. 3-5, and Joseph La Palombara and Myron weiner eds., Political Parties and Political Development. Princeton, Now Jersey: Princeton University Press, 1966, pp. 35-36.

9 .La Pụlómbara and Weipar, 1966, pp. 95-36. $\dot{-}$

10 Rothstein, 1976, p. 706.

a. .

11 Robertson, 1976, pp. 4-5.

12 A. H. Somjee, Political Society in Developing Countries, London: Macmillan Press, 1984, Preface xi.

13 Anthony Döwns, An Economic Theory of Democracy, New York: Harper and Row, 1957, pp. 36-50..

14 Robertson, 1976, p. 5.

15 Lucian W. Pye, Aspects of Political Development, Boston: Little . - Brown, 1966, p. 77.

16 sce Robertson, 1976, pp. 177-18i.' also see Carl Stone, Demacracy and Clientelism in Jamaica, London: Transaction, 1980, p. 185.

17 Downs, in̈57, p. 99 .

18 Robertson, 1976, p. 181 
Chavter I

19 D.E. Butler and D. $\vec{E}$. Stokes, Electoral Chunge in Brituin, Iondon: Pelican, 2nd ed. 1971, i. 240.

20 Stone, 1980, p. 185.

21 Rex Nettleford, Forcword, Caribbean Quarterly, vol. 27, No. 1, March 1981.

22 Robertson, 1970, pl

23 sce for example, J. Schunpeter's-Cupitalism, socidisim and

and Democracy, New York: Harper \& Row, 1950, and Downs, 1957, 1pp. '52-5,5. .

24 Robertson, $1976,17 \cdot 17$.

25 Ibicl. P. 18.

26 Ibigi. p. 18.

27. Gabricl A. Almond, James 5 . Coleman "eds, The polilies of the" Developing Axeas, Princeton, New Jersey: Princeton University Presi;, 1960, p. 538 .

28 fe Seymour M. Lipset's "Some Social Requisites of Democray: Economidexvelopment and Political Legitimacy," Ameriean Politicul" Science Review, Vol. LII, March 1959., pp. 69-105, also Almond and Coloman, 1960 pp. 338-543; and C.H.Kramer, "Short-Lerm Fluctuation:; in $U_{C} S$. Voting Behavior, 1896-1964., Nmerican Political Science Review, Vol: 65, 1971., pp. 131-143.

29 ․o. Koy, parties and Prossure Groups, Now York: Crowe12, 19.1 , pp. $209-214$.

30. Leiserson, 1958, p.. 309.

31 Robertson, 1976; p. 109.

32 Lciscorson, 1958, p. 309. 
CHLAPTER TWO

POLITICAL PARTIES IN JAMAICA: BACKGROUND to THE 1970's.

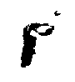

Jamaica is cne of the four najor islands in the Northern

Curibbean forming the Greater Antilles. It is the largest island of

the former British west. Indies at 4,411 square miles, and has a "current.

population of 2.3. million. ${ }^{1}$ Approximately 30 percent of tile population.

live in the capital city ố kingston and tire adjoining parishi, st.

Androw, which together form the major urbain fenter.

Socio-cconomic Class Structure

Over 90 percent of the Jamaican population are of African and African-European descent. The remainder consists of Europeans, Chinese, Lebancse, Jews, East Indians and other mixtures. 2 Jamaican society can be roujhiy divided between seven classes on the basis of their economic status. (See Table 1). ${ }^{3}$ The various class groupinis. havo a particular significance to parties seeking succosis in election for public office. The first two groups total about, 40,000 individuals,. and in addition to their financial contributions to political parties, they effectively, control the information disseminatad to the middle and - lower classes. 4 It is the members of the upper-classes who control the most widely read newspaper - the Daily Gleaner which began in 1834 . This paper has long been recognized as the voice of the "national bourgeoisie" 5 and of the "capitaiist enterprise alliance with tho West and a conservative sensibility." 6

The third and fourth categories account for approximately 400,000 indiviciuals. While the upper-classes control the top levels of 25 
private media institutions, it is the lower-middle classes. which are the greatest consumers of media information. 7 Members of these classes also participate directly in elections by running for office, stuffing campaigns, and supporting parties financially with small individual contributions. The "labour aristocracy" is also the mainstay of the two major trada unions - the Bustamante Industrial Tradé Union (BITU) arid affiliated witi the Jamaica Labour Party (JLP), and the National. Worker's Union (NWU), "affiliated with the People's National Party (PNP). The remaining 79 percent of the population form the lower clusses. |Becausc the middle and upper classes are concentrated in the main urban centor; "the lower classes are the "most "important in terms of shecr numbers of votes in most constituencies. In 1980 , the electorute was composed of 990,417 voters therefore, all parties must. appeal to this vast group to achieve electoral sucicess. 9

Another role which some members of the chronically unemployed class play during the election campaigns is participation in political gàng "warfare. . When politicians provide ghetto youths with weapons and sometimes salaries and other privileges in return for their services as 'soldiers' " for political street batitles." 10

In the Jamaican social and political structure, ethnicity and. class are incxtricably linked. This is a legacy of the colonial plant-: ation society and especially of the racia'l hierarchy wich prevailed. cari stone, 11 estimates that most of the "capitalist" class - the top 0.5 percent of the population - are Europeans, Jews, Lebanese, Chinèsè and persons of mixed race. The administrative class - another 0.5 per- cent. is mostiy brown-skinned. Although a number of dark-skinned persons. have accuired power and wealth, whites, ethnic minorities and lighter 
colorid people dominate the upper classes. David Lowenthal 12 estimates that in the late $1960^{\prime}$ s, the median Naje for winites was almost twice that for browns an "thirtecn times that for blacks.

\section{Economic and Social Conditions}

Throughout the 1950's and early 1960's riphd iconomic grovih , took place in Janaica which led to significant transiormations in the isländ's economy. 13 wiereas in 19.18 the traditiondl exports, (sujur, bananas and other agjricultural products), accounted for 90 ,jercont of reçeipts, twenty years later their shafe in the välue of whouts had shrunkened to 22 percent. The displacement of these dyriculturar exports was achieved by three main how commodity and enteristise grothi. These were bauxite-alumina, tourism and mamaracturing. ${ }^{14}$. Mheir. respective contributions, to the island's exonomy in :1968 were is fallows:

TABLE 2. Jamaica: Contribution of tajor Sectors to the value of Export Receipts. (1908)

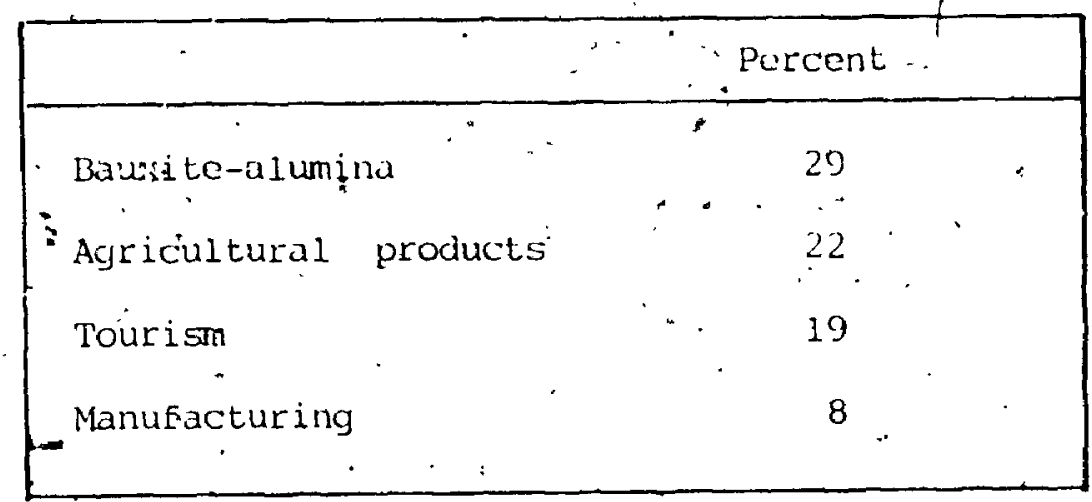

Sớurce: "Girvan 1971: 244

During this-same period, foreign trade inçrased eightfoíd, nominal.GDP grew sevenfeld, and́ per capita income aiso grew by 700 percent. 'In real terms, GDP. growth averaged 5 to 6 porcent per annum 


\section{$\boldsymbol{t}$}

ovarall, and 3 to 4 percent per capita. This impressive économic per-" formance was based upon massive. inflows of foreign capital and a prodigrous growth in imports for the island's productive system. "Between 1953 and 1972, foreign investment financod 32 percent of total

investment.' Imports of raw materials, fuels and intermediate capital goods grew far more quickly than. total inports, from 26 percent tó 36 percent. 15 Thus, lócal production abtivity bècame increasingly dependent on a regular, uninterrupted supply of imports; at the same time as imports became increasingly dependent on external Einancing. ${ }^{16}$. Erom 1950 to 1966, Jamaica received fóneign iniestmentsof US\$ 406.6 milition, 58 percent of which went into the mining sector. 17 By the lite 1960's more than half of all economic activity on the island was roreign owned. ${ }^{18}$ Foreign ownership of the main economic sectors of the economy was as follows:

TABLE 3. Jamaica: Foreign-gmersinip of Main Sectors. of the Economy (Late 1960's)

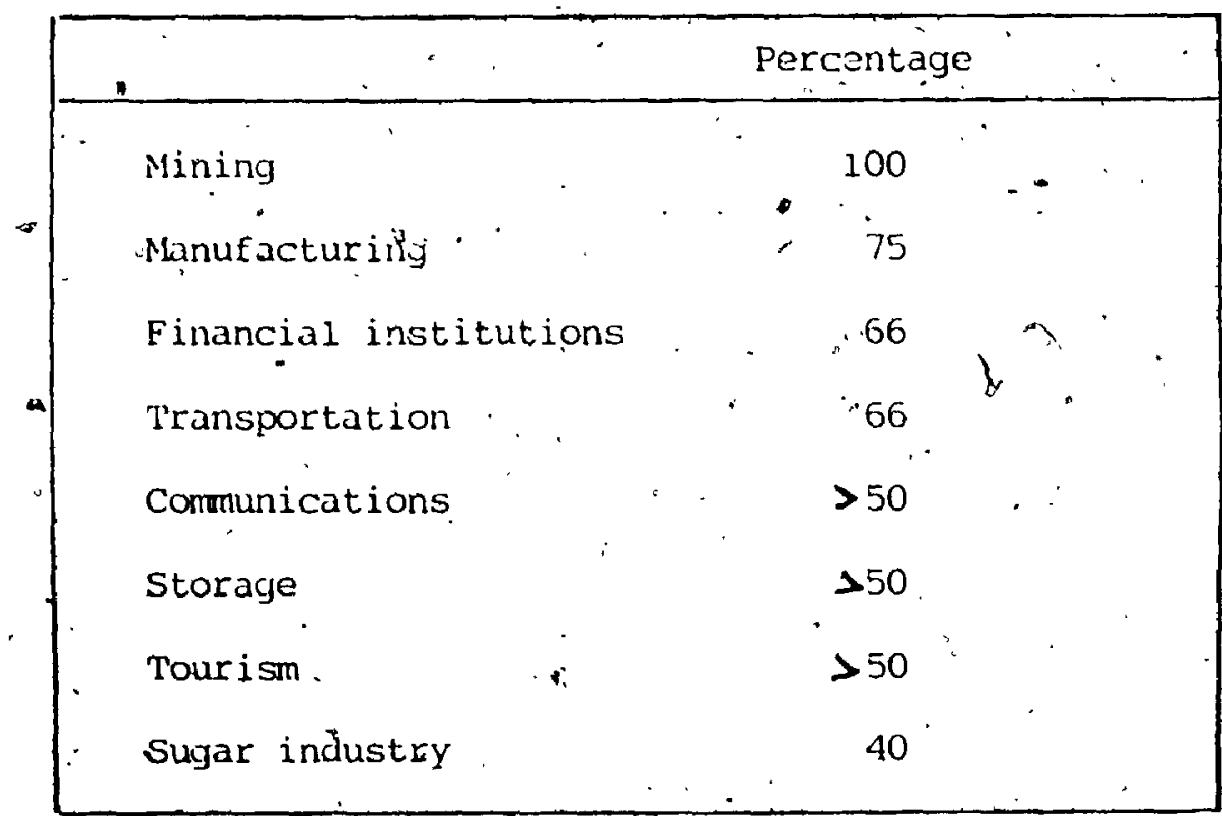

Source: EPICA Task Force 1979: 52 
By the early 1970 's, a series of internal, and sxterial political and economic crises" led.to a sharp decline in the economic growtin of the country. Between 1974 and 1980, cconomis growth daclined by a total of 26 percent. This decline was uccompanied by a seriud.; rise in economic and soceial problems for the majority of Jamaicuns: Health services and education bidly deteriorated. Unumployment, alroudy

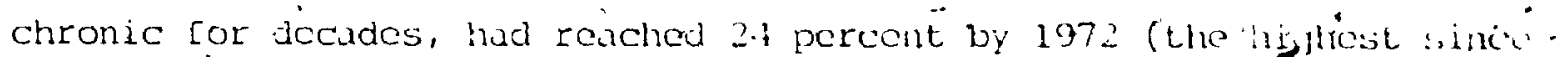
1943 when it 'stood at 25.1 percent), 19 ' and coithinued to rise. 'lhie principal productive sectors of the-economy = minnos, munufucturim, agriculture and tourism - were performing far ixdow timeir capmiltici; political violence became commonplaca; income distrlbution and kuld ownershi? were badly skewod, and a massive rlight of capital thromidhod the '1970's chained the ceonomy.

Althougit there had been modorate improvecments in public horlth and education in the decades before and àfeir inclependence, the distribution 'of wealth decluing erom extensive conomic growth wifs extromely uncqual. By the mid-1960's, Jamaica hold the oxistinction of having the world's highest level of ineguality, with the varthiost; percent of the population recoiving 30 percent of the nationil incom. and the poorest 20 percent receiving only 2 tercent. $2 \mathrm{~h}$. Hy the and of the 196015 , these condition's led to helyintened demands by the most disadvantaged sectors of the sociaty for grodter equity in tho suciul: and economic policies of the goverument.

The Structure of Government

According to, Trevor Munroc, In Jamaica, as in most cólonics : facing independence, the emulation of the colonizing power ramains a : 
striking paradox of the process of docolonization." 22 The two political: partics chose not only to maintain the economic policies of the status quo, but also to adopt a constitiutional form of government similar to the't of Groat Britain.

The furmal structure of government 23 was established with the rull consensus of both parties, by the Jamaica (Constitutiont order in Councia, and was approved by the Britisb Government on July 23,

- 1962. Hence, Jamaica has been a constitutional monarchy and a fully 'self-yoverning member of the Cormonwealth since' August 6, 1962:'

The British Monarch is the tltular sovereign, and the Governor" General, the formal head of state. All significunt executive" power and all effective legislative powers are concentrated in the liands of the Prime Minister and his Cabirrt, which must consist of at least eleven momivers. The cabinet is the center of government, initiating all jovernment policies and projrams and sharing a collective responsibility to Parliament.

The Senate consists of 21 appointed members, 13 upon tive recommendation of the Prime Nínister, and 8 on that of the Leader - QE the dopesition: The House or Representatives is chosen by popular vote from constitupncies. "The House must consist or at least 45 members, but no more than 60 members.

The Opposition is recognized as a fundamental pare of the political process. 'The Leader is a mamber of the House of Representatives, and is supported by a majority of members not in the ruling party.

An Attorney General is the principal legal advisor to the government. The Judicial system is based on English Common Law, but some accommodation to local needs has been made though statute and 
custom.

Jamaica has also adopted from Britain the 1 dew of a neutral and professional civil service. The top clvil servant in each Ministry is the Permanent Secretary who serves directiy under the Minister. However, despite the endorsement of neutrality and professionalism, the civil service is thought to suffer severely from the "spoils system." Finally, local government is not mentioned in the constitution, and its structure and powers ar subject to determination by Parliament. Jamaiça is divided into Eourteen parishes and each parish providos lexil .community services, for example, homes for"the poor, samatation, paruchidl road maintenance, water, fire protection, eta. Its funds come from special rates and taxes collected by the central government and from grants from the central government.

\section{Voting Patterns}

Under the Constitution, Parliament is elected for a maximum of five years, but may be prorogued or dissolved at any time. Since Jamaica was granted universal suffrage in 1944, each party has won two terms in office followed by two terms in opposition. This pattern hus" remained unbroken over ten general elections. 24 (See Table 4.) The 'tenth general election, held in December 1983, was unprecudented in Jamaica's political history, in that it was, the first to bo uncontested by the opposition PNP. As a result of this election, all sixty seats" in parliament are held by the JLP government at the present timie.

Since the first election under universal suffrage, no third party has threatened the dominance of the two main parties - the JLP and the PNP. Although independent candidates and third parties 
received 35.1 percent of the vote in 1944, their votes dwindled to. u. 13.8 percent in 1949 , and 10.5 percent in 1955. Since that time, none has gained as much as 2 percent of the vbte. 25 .

I'ABLE 4. Jamaica: Analysis of Popular Vote, 1944-1980

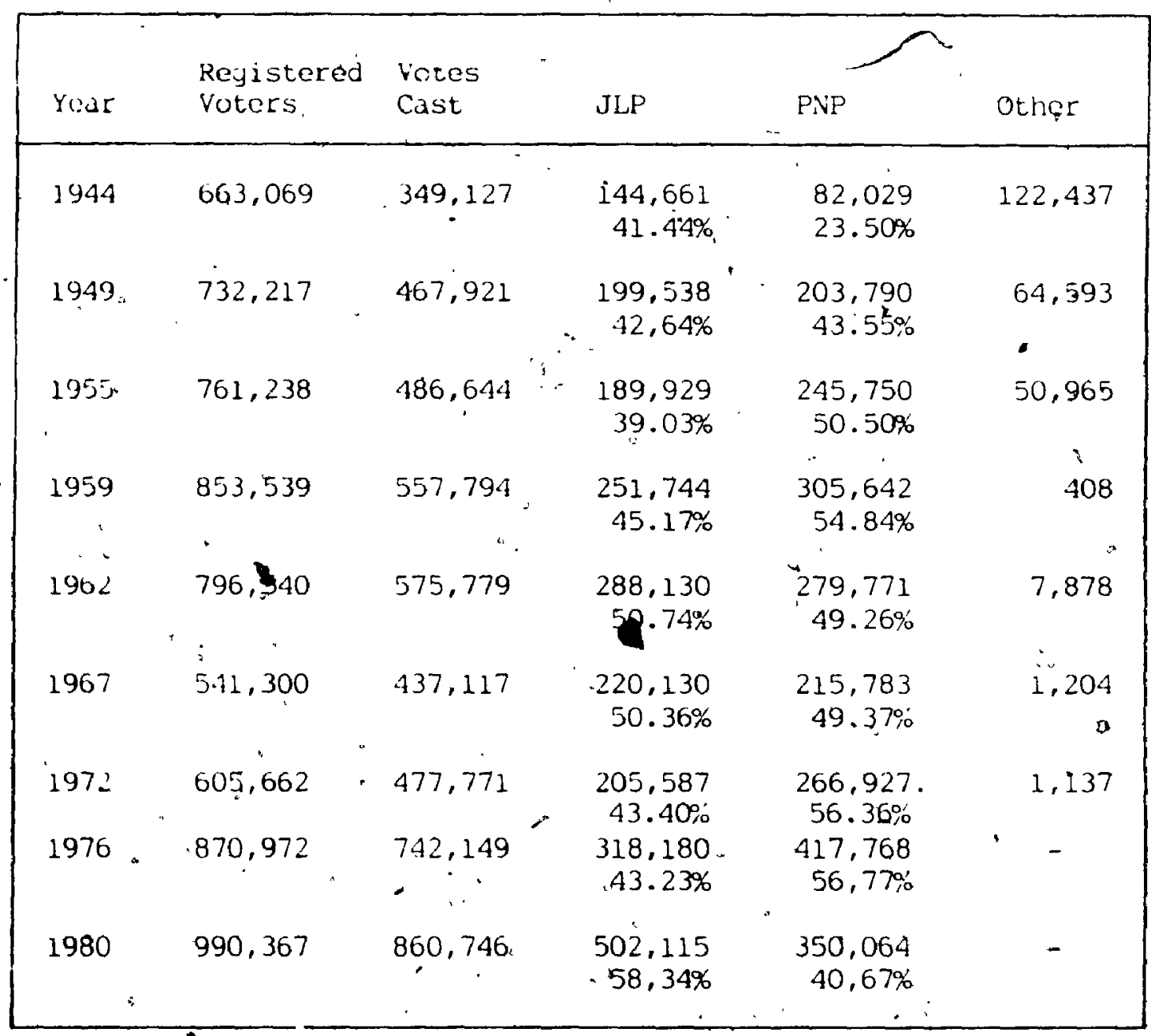

Source: Chief Electorai.officer Repörts, Kingston; Jamaica 


\section{Origlns of the Political Parties}

The present political system in Jamalca pmeryed in the wake of labour (unrests that swept the island in $1938 .^{26}$ The founding leaders of hodern Jamatcan political parties emerged as leaders rrom these qisturbances.

The first was Alexander Bustamante; the son of an Irish furmer and creole mother. With. little Eurmul education, he ruse to chumpion the 'woryer's cause and was jailed between 1940 and 1942 as a result of his activities. Emerging as a hero, the took the lead in or funizing lho - labour union (the Bustamante Industrial Trade Union) and appointed himself its president-for-life.

The second political leader, and founder of the first politicul party, the People's National Party, was Bustamante's cousin and carly ally, Norman Washingtor Maniey. Manley was a Rhodes scholar and a brilliantlawyer, whose interests lay more in the causes of selfgovernment and universal suffrage than in the dabutr movement.

While Bustamante was detained by the British authorities, Manley and the PNP hierarchy continued to oversee the trade union. Between 1940 and 1942 they succeeded in raising the membership from 8,000 to $20,000.27$ Soon, however; the sharp differences in style ard outiouk - between the autocratic, self-educated Bustamante, and the intellectuil statesman Manley, broke, the delicate alilance petween the wo leaders. ". The PNP continued to press for constitutional change and universal sufflage, and by 1944, these were granted. In preparation for the rirst: general election that year, Bustamante hastily Cormed the Jamaica-" " Labour Party (JLP), which was "little more than a transformed BITU designed for election purposes. "28 
Before the 1944 general elections, suffrage based on ownership of land and largely restricted to the island's elites. In the seven elections of the Legislative Assembly heid between 1901 and 1935, oniy 6 percent of the population was eligible to vote and no more - than 3 percent voted in any one electian. 29 By 1944, however, the sizè : of the electorate increased tenfold. "The JLP won 22 seats" with' 41.4 percent of the vote and the PNP won 5 seats with 23.5 percent of the votes.

By 1959, Jamaica had become selfzgoverning in all aspects except foreign policy. In 1958, it hád become part of the Federation of the West Indies, 30 under the prompting of Britain. Britain sought to. uniry Jamialca and other Colonial territories in the region in an attempt to consolidate a trading bloc between Britain and the west Indian colonies before granting them independence. However, in - the 1958 Federal elections, Jamaica failed ta gain a majority in the Foderal parliament and the ruling PNP called a referendưm in. 1961 to determine Jamaica.'s continued membership. Although both party leaders had supported the Federation, Bustamanté seized the opportunity $\therefore !$

"to campaign against it during, the referendum claiming that membership

- would mean Jamaica's tubjugation to 'Trinidad and Tobago. Manley's PNP government voiced strong' support of Jamaica's continued membership in the Federation, while Bustamante calied for "freedom" from Trinidad"s domination. With a vote of 54.1 percent against and $45: 9$ percent for, Jamaica witharew. The JLP, on the winning side of the Federation issue, was returned to power in 1962 and led the country to full. - independence on August 6́thi, 1962. 


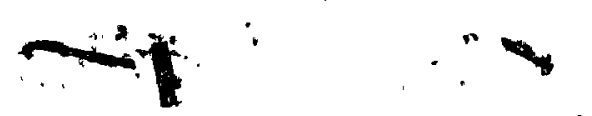

spen, tradi'ion of the $\$ 1930^{\prime}$ 's struggle. ${ }^{34}$ Yet, the JLP had a conservative pro-capitaiist ideology, which sought, in the words of its leader, "to provide only "a littlé. more bread and a little more butter" for the working clusses and the peasantry. 35 According to carl stone, 36 , the JLP was more "incrementalist, " oriented to short-term adjustments" in its roform ideas.

It's imcremientalist viéw' of change was rooted in the low level of elass consciousness of its. mass buse, which articulated angry militancy towards the capitalist elasses but had no aspirations for state power, ownership and $\because \quad$ control of the mean's of production, or a. strorig, sense of class solidarity.

Hence, the JLP and its union, the BITU, provided the political" expression for this anti-capitalist class; while firmly supporting the British Eripire as'"a God-givon instrument of democratic, rule, and attacking communism and even, the PNP's socialism." 37

The PNP's version of nationalism relected it's "consequent cosmópol itan, regional, outward-10oking and internationalist perspative." while the JLP has been basically parochial and localist in its view of

$\therefore$ nationalism." 38

$\because \because \quad$ Ironically, the PNPis blending of moderate nationalism and elements of Fabianism wềre viewed. by the island's ruiling oligarchy as a .

$\therefore$ - yreater threat to their interests, than the JLP's support of the radical. 'working classes. Some of the PNP's socialist policies inclyuded the' advocacy of à marketing and industrial poard to provide easy credit to. small capitalists and middle peasants; the curtailment of largé-scale capitalist agriculture, and the formation of rural co-operatives. 39 When the oligarchy's own political party - the short lived Jamaica 
Democratic Party - was badly defeated in the first elcction, it turned towards "the volatile and co-optible Bustamante" is the pọlitical instrument of its interests. . In "of fice between 1944 and 1955, and 1962 to 1965, Bustamante became a slavish defender of the interests of British and American imperialism." 40 In fact, during the 19.19-

* 1950. period whep the Attlee Labour, Government in Britain proposed Lhe

mationalization of tate and Lyle - the glant sugar monopoly which dominated Jamaican agriculture - Bustamante threateried to call islundir wide strikes in opposition. 41.

While both parties have had differiny ideologies from thoir inception, the JLP's capitalist, pro-Western orientation has beon consistently articulated and adopted in it's governing policies. The PNP!'s "socialism," however, remained up until 1974, a.guiding principle" rather than a platform appeal or policy. As such, the cbuntry did not" experience the effects of "ideological-turnover" (discussed in chupter one), which might have resulted if policies were consistently reversed by alternating governments. 'Nor did the country experience the destubibizing consequences of competing partics, as did many devcloping couritries In their post-independence political, struggles: While the two Jamaican political parties offered little in the way of. innuvative pabiticul choice and scarcely encouraged active mass participation in political " decision-making, their convergent policies did allow for the growth of - a stabre and .me institutionalized political system.

\section{Intepst Groups and the Dexelopment of Party Power Base}

Economic and material objectives provide the major rationale and the nighest priority in ind fidual and collective political action. $42^{\circ}$ 
The system of wedlth distribution defines the objectives of the various interest groups (1isted on Table 1), who have a conmon stake in the system based on the sources and quantity of wealth that accrue to them. ${ }^{43}$ Each class seeks to maximize its economic interests within the limits of its perception of power and bargaining position . . Political behaviour at every. institutional level represents convergent and conflicting attempts to maximize the defined group interest . . . Access to and the distribution of wealtin are the central issues determining: alignments, coalitions, gad the antayonisms in the political arena.

'The various class groupings, which refiect the strata of wealth distribution, was woll represented in the broad class bases developed by both parties over the years. Neither party could be viowed, in the clássical sense, as being more associated with one classs or ethnic ." group or another. There was; however, the tendency for both parties to attract more support from certain groups thapdijes. The PNP, for example, was, up to the late 1960's perceived as "middle class" because it attracted the míddle and upper-class intelligensia, and the urban working classes. Whereas the JLP had been perceived as the party of upper capitalist classes, "as well as the poorer rural and urban classes. These perceptions were rooted in their earliest class asșóciations."

Bustamante was a populist leader in the sense that he presented himself as. a representative of the "common" people, without a rigorous ideology. 45 But he also gained the support of the capitalist upper classes, who, according to Paul Blanchard, 46

"were gratified by his political views. He supported the British Empire as a God-given instrument of democratic-rule, and attacked communism and socialism . . Many conservatives supported him privately because they -thought that his crude dictatorship was less dangerous to their property rights 
than the opposition labour movement led by Norman Manley.

In contrast, the PNP reflected the interests of the "petty. bourgeoisie, middle peasants and small truders against the encroucluments of the big. landholding class and comprador bourgeoisic." 17 Its carilicst. . leadership was formed from the middle class professionals, civil servants - and rntelligensia. Thus the PNP developed its early shpport from those sectors between the upper capitalist classes and the poorer socturs of the society. After the first election, however, the PNP discovered that these groups alone could not sustain the purty when the electorate wats overwhelmingly lower class. Like the JLP before it, the PNP soon found that union leadership was the most expeditious route to pirmunent politicallimportance. "The only way, to achieve mass appeal, because. of universal suffrage was tó organize a labour union and idencify purty with it." 48 .

- In spite of their broad mass base, neither party could depend on Einancial support erom their rapk and ille mombers. Therofore: cuch " party courted the support of the wedlhier classes (i.e. merchints, und big industrialists), who were interested in the "good wili" of the " party leaders. According to Morley Ayçarst, 49 both partios woro illeged. to enjoy secret gifts of considerable; amounts from these groups. After the JLP victory in Ene 1907 clections, a random siam 110 of polling district's in tind urban center' was taken, and the results showed. ' that the JLP had gained its traditional support in the upper classos and the pooror, sector of the lower classes, while the PNP. base of support continued to come from those in between - the uppermost sector of the lower class, and the lower middle class. 50 
Although some 80 percent of Jamaicans are very poor, and a small group of individuals control most of the wealth, conflict among class groups was not a factor in election campaigns prior to the 1972 . elections. The JLP, which had traditionaliy been considered the representative of the poor, spoke only of class in euphemistic terms, imaintaining that a yovernment could function in the interests of all clusses sinultaneously. A small proportion of PNP members sitrove, a,t this time, to present the party prograt as being in the interest of the lower class; 'but inimical to the interests of the wealthy. Some programs, such as a minimum wage and the abolition of the Master-Servant. Law, were promised, 51 but no serious attempt to make far-reaching chinges in the social. structure was promiised. Thus,

between 1952 and 1974, socialism remained a guiding principle within the PNP, rather
than a platform appeal to the electorate.

\section{Electioneering and the "Rational" Electorate}

$\therefore \quad$ In chapter one, the methods used by parties to apearl to the electoratẹ were discússed, and'certain assumptions made which suggested that political parties, tended to use idealogical argiments to appeal to the desires of voters, rather than attempt to explain concrete policies to an uncritical and largely illiterate and partisan electorate. "Thése " assumptions will be examined against the electoral strategies of Jamaican palitical parties. An indication of the degree to which the majority - of the electorate are actually involwed in the effective formation of party policies will be'givert.

As this study has already indicated, the only parties that could win an overail majerity, based on universal suffrage, were those which 
appealed to the aspirations of the lowincome voters. Befure the 1970's, Jamaita was conspicuously lacking in community-wide oryanizations that identified with their needs and aspirations. Thercfore, the unions became the most important means of mass organization, at least for the working poor. Both parties provided the mass representation through their union affiliates, "which was essentiully politicul.".

i Thus, "the successful political party wa's a labour one, in many cases paying lip-service to socialism, and always, stressing the 'Nationalist' ideal:" 53 Prior to independence, the national idedl meant mure self- : government for the colony" and, a rapid advance of political independence. Thus, both parties pledged to satisfy the two most urgent - yct vaguely defined desires of the voters - "to improve their economic status and to become full members of their society." 54

These demands were largely based upon desires, values and expectations, and "emotional needs, father tlan" on any important economic analysis." $"$ " This rendered the effective political afgument an emotion-charged, ideological ond. Howcver, the perceptions of "objective reality" by both'parties prior to the 1970 's, produced an adherence ţo the more pragmatic approach of compromise and moderation. in their actual policies.

- 'Parties continuéd to be elccted by voicing the ideological demands of their forlowers, and appearing to be the people's champion against colonialsim, and other perceived forms of exploitation.

In tems of effective mass involvement in political decisionmaking, J. Schumpeter's statement ${ }^{56}$ that the sole function of the. electorate is to choose "lock, stock and barrel" one paity or another every f.ew years, had largely held true in Jamaica, prior to the $1970^{\circ}$ s. 
Local party groups were generally few in -number and inactive except immediately before elections. As Ayearst obscrved, 57

The accepted party leadership decides candidates, and the party structure is hierarchical, with the rank and file voter playing very little part other than voting at elections. The party structure is demogodic rather than democratic . . There is no close and working organization for the reassessment of leaders and the deciding of issues

- on a broad party basis.

A final point which may" be noted is that both parties tended to converge in organization, policies and class content, as they became - more established. The uitimate result of this increasing convergence was the effective exclusion of the masses from real political participation and social rewards.

By examining the policies which informed the two parties' approach to governing, the "convergence" of policies, and their subsequent implications for national development become more evident.

\section{Party Palicies}

Perhaps the most outstanding feature of party politics in Jamaica, since the early 1950's, was the growth of consensus-between the JLP and the PNP. A decade after independence, these tendencies continued in relation to socio-economic policies. Both adminlstration's followéd conservative policies, providing módest public programs and sceking to attract forcign investment. Louis Lindsay ${ }^{58}$ argues that sindependence was "mythical" in the sense that Britain granted independence only after it was assured of the loyalty to the west by both leaders of the two parties. Indeed, neither party challenged the Western democratic form of government" or the power of foreign investments. 
Owen Jefferson 59 found that successive Jumaican yovernments took a three prongè approach to national planning, "the enunciation of certain iroad policy goals; the provision of incentives, and the reifance on private enterprise to jet on with the -yob." like role "of the government was therefore 1 imited to "the provision of educiation', health segvices, agricultural extension services, and uther"similur forms of basic investments, together with the manipulation of monetary and fiscal policy to provide what it regunded as a desirdble economic climate."

One factor which șeens to have influenced the yoverument:; against a greater degrce of regulation and control of the economy, appirs to have been the desire to attract forcign capitul. "In alt throc postwar independence plans, there was the implicit assumption that corciun investment was the variabic to be maximized. "60

The economic policies of the governments of both purties, tip to the 1970's was a policy of "cconomic growth" dependent upon international capital" and the creation of a "welcoming society" for forcign capital, under the jeneral rubric of "industrialization by invitution." 61 The most important factor wich influenced official poilcy was the Fomento Projram in Pierto Rico, wilch gained the nickname, "Operation Bootstrap." Basically this meant the gojernment's provision of incentives (for example, tax hotidays; cheâp labour for manufacturing, and infrastructural facilities - rọads, electricity, etc. for the muning and. tourism industries), to attract foreign investments in these industries. 62

By 1950, the grdat North Americàn àluminum monopolies - Alcod, Alcan, Kaiser and Reynolds were investing millions of collars in the exploitation of Jamaican bauxite reserves, which were estimated to be the 
lurgest in the world at that time.

Thus, officił policies. encouraged and welcomed foreign capital, which provided the technology for a tremendous diversification of the ecunomy. Dripite the diversification, the post-war developments reinforced thic basic import-export orientation. of the economy. Virtually Wb1 the imports, (raw materilis, services and even skilled manpower) were - imported by the mining, manufacturing and tourist industries, while all the-Dakiite and IIuminum, and much of the manufacturing, (which chicery involven the importation of components to be assembled) was exported. 63 - Larjye-scale agricultural" production, though considerably" reduced, also" contributed to the export market.

Although the new sectors were primarily foreign-owned, their investments created profitiole opportunities for the capitalist classes. "Members of the old oligarchy began diversifying their economic activities into construction and related supplier industries, forming the nucleus af $\&$ tho new industrial bourgeoisic."64' Merchants traded largervolumos " consumer goods and faw materials for. industries. Some became manufacturers in import substitution industrics, (for example, consumer goods and clothing). Speculators, got rich through real estate dealings, and new $\because \quad$ entrcpreneurs emerged in the service industries. In short,

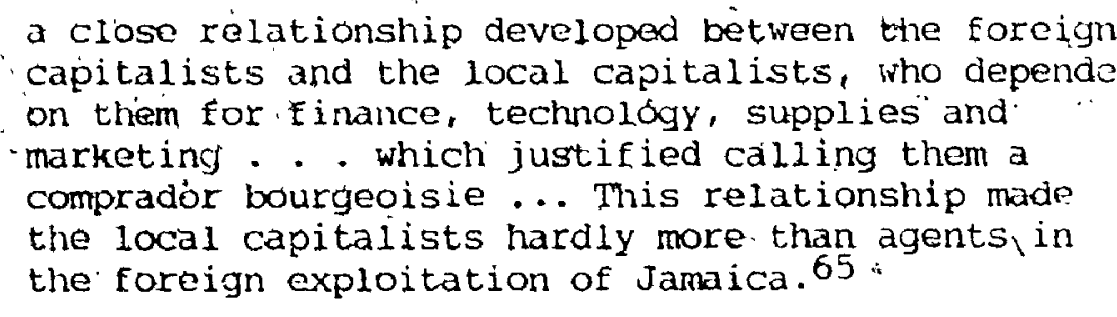

in addition, the state bureaucracy grewn, creating new jobs as decolonization proceeded, and middle level economic management, administration and technical expertise were passed on to Jamaicans in the 
administrative upper classes.

\section{Policy Implications for National Devolopment}

In examining the policy implications for development, "cconomic.

growth" and "cconomic development" are terms which recfuirc cultuill

qualifications. To begin with, nelther growth nor development cun, we

defined in "value-free" tecluical terms. Economic yruwth, (in the

conventional sense of increases in the per capita production of foods

and services), can be feasured only if cortain assumptions are made

about income distribution. 66

The weights to be attached to the different goods and services making up the national product, or income, depend on relutive prices and these relative prices are linked to the distribution of income. 67

When economic growth is wedded to the concept of development, uther elements, such as a satisfactory level or employment; a fairly fuad

- distribution of income, and the greatest possible participation by lhe

$\because$ "people in the nation'sfyconomy, must, be taken into account.

The impact of the Jamaican governmonts' economic policies hud Ear raaching implications:

By 1962, the result of the economic policies

of both governments was a disarticulated

economy, which produced disjointed sucicty

and a. comprador polity. ${ }^{6}$

Foreign capital stimulated rapid yrowth and change in sume scelors

of the cconomy, while stifling them in others. "It strengthened the hold

of foreign capital over the resources of the country, and deepened the

economic ties petween Jamaica and the advanced econumies of Nurth

America." 69 


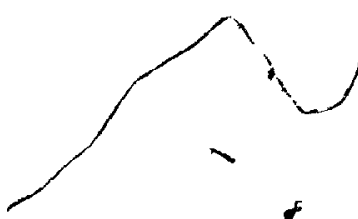

- By 1962, 39 percent of trade was with the United States, and

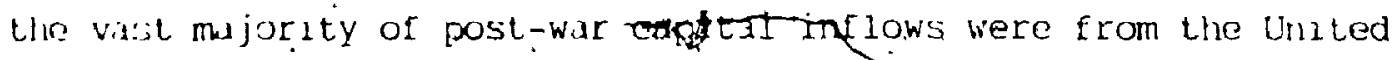
Shati: in the form of investmants. 'By 1965; manufacturing had grown from its, infalky liventy yeurs carlios, to 15 percent of the GDP. The laikite-alumina industry contributed 10 percent to the GDP in 1965, and rourism, which compicted the briad of economic diversification, showed a quacirú,ling of the number of visitors to the' island between 1950 and 1905.70

["rese impressive results lerg directly attributed. to the hiylly ;rowth-oriented economic policies and plans of the governments. But the berefit: of growth were unequally distributed. Foreign investors yot the -lion's share of prorits. The bulk cf the remainder was shared between the locil capitalist ciasses and a high salaried manajerial alte. For the majority of people, unemployment was high, wages were' low and the difference in the ștandard of living between the ruling classes and the masses jrew wider.

The motion of the economy produced contradictory results, incrcasing wealth on the one hand, while increasing relative poverty on the other, and producing sharp conflict between groups, "and - increasing instability. 71

Bctween 1962 and 1972, unemployment increased from 13 percent to 2.1 percont, while the share of the poorest 40 pericont of the population in personal income declined from 7.2:percent in 1958 to 5.4 percent in 1968. 72 Inspite of the economic growth of the $1950^{\prime} s$ and 1960 's, the unequal distribution of wealth contributed to frowing social' discontent, which was manifested in unprecedented urban violence. The general response to urban sociar and economic unrest by both political. parties was to use police and military forces to maintain "law and 
order," and to call for increases in the country's securily estabi istument. rather than to Jdidress the real sourco of discontent - muterial deprivition. For cxampled tine jorcrumont allocated more money to Defence.

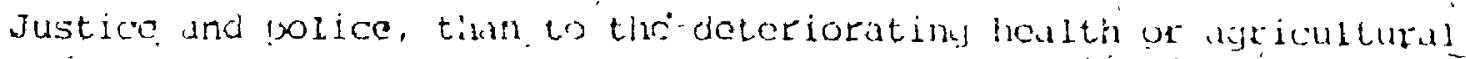

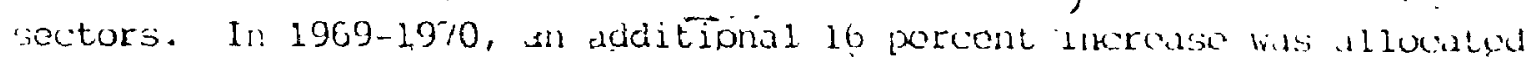

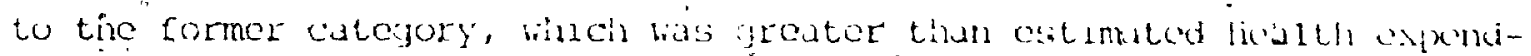

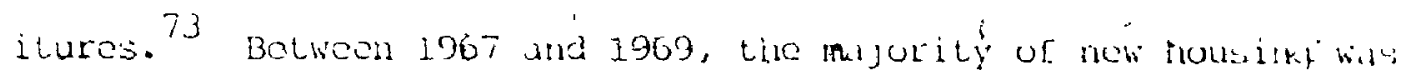

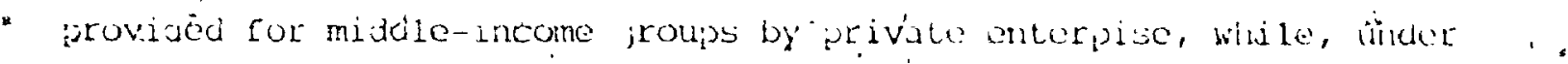

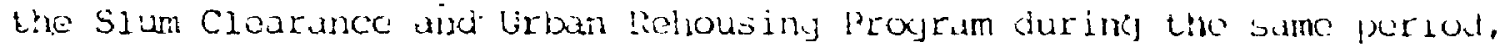
only 232 structuros were built. $7: 1$.

These are just a few exumples of the issties ritsod in the 1972 election campaign. Although the full impact of cxturnil forcuse (i:c.

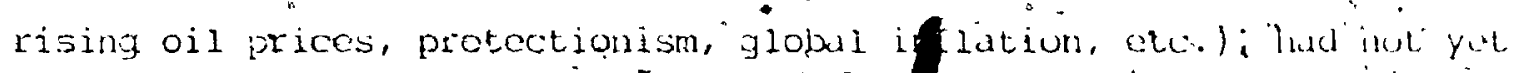
been felt by the society, the results of the jovernincials hishly yruwhariented policies; its heavy dependence on forpign cupilit, and ils. reliance on "trickle down" solutions to distributional problem., froduced. the forces to be reckoned with by the late 1960's, as demungis for yrewher

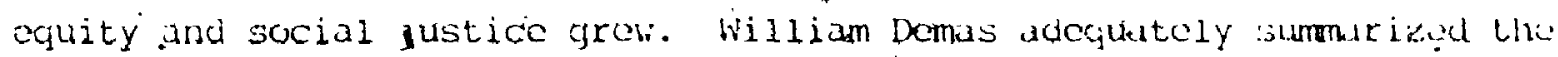
situation as follons: 75 .

Economic policy anci planning tave been highty growith oriented. in the bebief that unce yfowth 'takes place, through exparision of the' activitios

V of international. corporations operating. in the country, and tirough the attraction of new branch plants in industry and tourism, the problams of the aconamy - unemployment; inicone: distribution and local participation, wouldef automatically be solved by some kind of 'invisible hand.'

Universal suffrage and the growing strength of unions and political parties gave the masses at least a greater forling of inf hu ho uver 
domestic affairs, however, these brought luttle fundamental change In the suciety and no attempts at substantive economic and socid reforms which could be deemed in the "best interests" of the majority.

1.

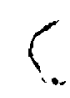

$\cdots$

$\because$

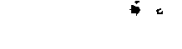


Chăpter I I.

References:

1 'hA Developing horld, : map, Canadian Internationul. Develupment Ajency, 1985.

2 Jamaica Election Factbook, Government Printing Orfice, Kimylon; Jamaica, February 21, 1967, p.3

3 see Carl. Stone, "Class and the Institutionulization of l'wo-jartey Politics in.Jamuica, Journal of Commonwedlh and Comparalive Polilicis, Vol. XIV, No. 2, July 1976, p. 129.

4 Anita M. Waters, Race, Clas 3 and Politral Symidols, Now Jersey, U.S.A: Transaction Books, 1985, pp. 27-29.

5 Torry Lacey, violence and Politics in Jamaica, 1900-1970: . Interllal Sccurity in a Developing Country, London: Frank Cass, 1977, p. 28.

6 Andrew Kopkind, "Trouble in Pararlise," Columbid Journalism Review, March 1980, pp. 41-42.

$T$ Waters, $1985, \mathrm{p} .28$.

8 G.E. Mills, "Electoral Reform in Jamaica," Curibbèn Quafécrly. Vol. 27, No. 1, March 1981, p. 20.

- 9 Morley Aycarst, "A Note on Some Charucteristics of Wast lindin Political Parties," Social and Econumic Studies, No. 3, Scipt, 1954.

10. Lacey, 1977, ir. 32.

11 Stone, 1976, p. 180.

12 David Lowenthal, West Indian Socictios, yow York: Uxítord University Press, 1972, p. 81 .

13 see oven Jefferson's The Post-War Economic Development of Jumaica,

14 Norman Girvan, Eoreign Capital and Economic Underdevelopment in Jamaicá, Kingston, Jamaica: I.S.E.R. 1971,.p. 244.

15 Eitzroy Ambursley; "Jamaica: From Michacl Manley to Edward Sedyd," in Crisis in the Caribbean, ed. Fitziroy Ambursley and Robert Cükn, Kingston, Jamaica: Heinemann, 1983, pp. 77-78.

16 Norman Girvan, R. Bernal and W. Hughes, "The IMF and the Third: World: The Casto of Jamaica, 1974-80," Development Dialojue; No. 2 . pp. 114, 133:

17 John D. Forbes, Jamaica: Managing Political and Economic Change; Washington, D.C: American Institute for Public Policy Reseapch, 1985, p. 12 . 
Chapter II

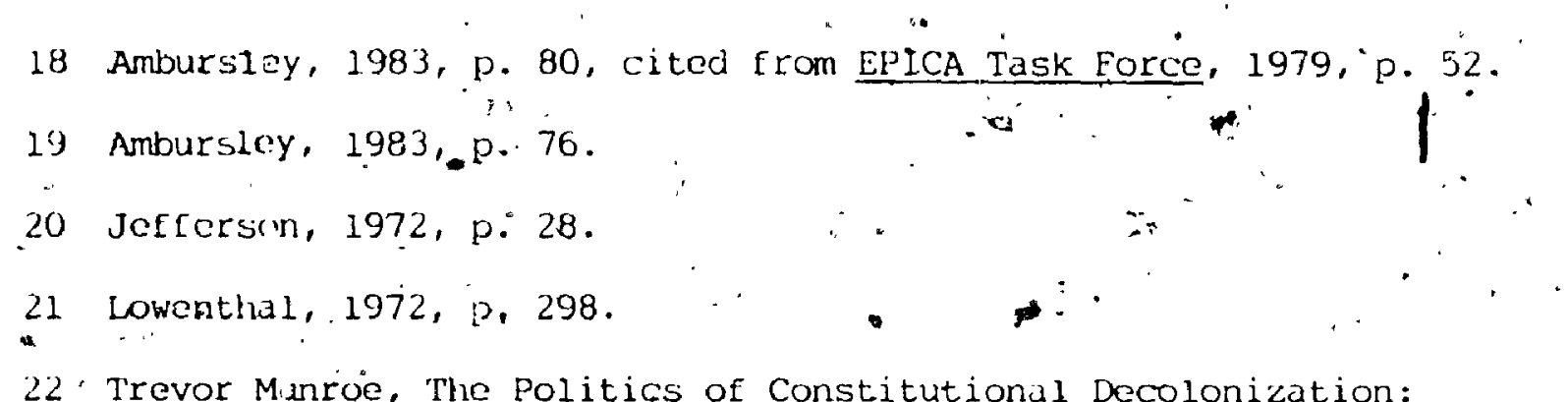

22. Trevor Manroe, The Politics of Constitutional Decolonization: Jamaica 1944-62, U.W.I : Kingston, Jamaica: Institute of Social and Economic Rescatch (ISER), 1,972, pp. 148-149.

23 soe The Jimaica Election Factbook, 1967, far more claborate details."

24 Figuras for the popular vote from 1944-67 taken from Munroe, i972, p. 205, and Erom 1972-1980 from Waters, 1985, pp. 91, 141, 200 and adapted. from the Jamaican Chief Electoral Officer's Report. For each :election.

25 Waters, 1985, p. 53.

26 Ken Post's mammoth study of these events provides váluable information on the genesis of modern Jamaica. See his Arise Ye Starvelings: The Jamaica Labour. Rebellion of 1938 and Its Aftermath, London: Martinus Nighoff, 1978. See also his, Strike the Iron, New Jersey: Humanitics Press, 1981.

27 Samuel and Edith Hurwitz, Jamaica: A Historical Portrait, Now York: Praejer, 1971, p. 198.

28 Rex Nettleford, ed. Norman Washington Manley and the New Jamaica, New York: Africa, Publishing, 1971, preface.2xx.-

- 29 Paul Blanchard, Democracy and Empire in the Caribbean, Nev York: Macmillan, 1947, p. 91 .

30 see Waters, 1985, p. 54.

is Gerhard Masur, "Foreign Political Idejologies in the Caribbean," in The Caribbean: Its. Political Problems, ed. A. Curtis Wilgus, Gainsville, Florida: Univ. of Florida Pross, 1962, p. 15.

32 Ambursley, 1983, p. 75.

33 Géorge Beckford and Michael Witter, Small Gärden, Bitter Weed, Kingston, Jamaica: University School of Printing, 1980, p. 62.

34 Ambursley, 1983; p. 75.

35 Beckford and witter, 1980, p. 63. 


\section{Chapter II}

-36 Stone, 1976, p. 183.

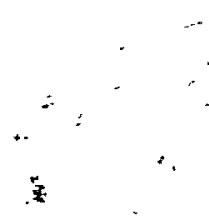

.37 Masur, 1962, p. 15, cited from Bianchurd, 1947, p. 94.

38 Stanc.; 1976, p. 183

39 Mmburslcy, 1983, p. 75:'

40 Ibid. p. 75.

- 41 Georje Beckfora, Persistent'Poverty: Underdevelupment in planlution Economies of the Third World, New York: Oxford University Press, 1972, p. 141:

42 Stone, 1976, p. 178.

43 Ibid. p. 179.

44 Ibid. pp. 178-180.

45 Waters, 1985, p. 55.

46 Blanchard, 1947, p: 35.

47 Amburs 1ey, 1983, p. 75.

48 Morley Ayearst, "Characteristics of West Indian Political Partics," in Aftermath of Sovereignty, ed'. D. Lowenthal and-Lambros Comitas, New York: . Anchor Press/Doubleday, 1973, p. 70.

$\because \quad 49$ Ibid. p. 75.

50 stone, The Daily Gleaner, $6 / 8 / 80$.

51 Waters, 1985, pp. 87-88.

52 Jolun Hearne, Introduction, in Search for Solutions, Michuel Manicy, Oshawá, Canada: Maple Housc, 1976.

53 Ayearst, 1973, pp. 69-70.

54 Ibid. p. 71

55 Ibid. p. 71

$56^{\circ}$ see introductory chapter, p. '4.

57 Ayearst," 1973, ऐ. 72. 
Chupter II

58 Louis Lindsay. The Myth of Independenee: Middle Class politics and Non-Mobilization in Jamaica, U.W.I., Kingston; Jamaica: I.S.E.R. Working Paper No. 6, 1975, pp. 2-4

59 see Jefierson, 1972 , for a summary of the three post-Wac National Develupment Plans, pp. 7-1.4.

60 Ibid. p. io

61 Beckford and witter, 1980, p. 64:

62 Ibid. p. 65.

63 Ibid. 2. 66.

64 S. King and R. Grrling, "The Caribbean Conflict," N.A.C.L.A. Report on the Americas, No. 12, May 1978, p.'10.

65 Beckford and Witter, 1980, p. 67.

66 William G. Demas, The Political Economy of the English-Speaking. Caribbean, 4th ed. Bridgetown, Barbados: Cedar Press, 1976, p. 16.

67 see Francis Stcwart and Paul Streeten, "Conflicts Between output and Employment objectives," "Cambridje, Overseas Studies Comittee Conference, 1970.

68 Beckford and Witter, 1980, p. $72^{\circ}$.

69 Ibid. $2 p .72-73$.

70 .Figures taken from Jefferson, 1972.

71 Munroe, 1972, p. 201.

72 Girvan, et a1, 1980' p. 115.

73 Economic Survey Jamaica, Central Planning Unit; Kingston Goverpment: printers, 1967, p.-111 and Economic'Survey Jamaica, 1969, p. 124.

74 Economic Survey Jamaica, 1969, p. 86.

75 Demas, 1976, p. 11. 
CHAPTER I I I

THE PNP YEARS: i $1972-1980$

In the late 1960's both political parties underwent leadership transitions after almost three decades under the tutalege of Alexander Bustamante and Norman Manley. In 1969, Norman Manley's sun, Michael Mánley was "elected to succeed his late father" as PNP president, in addion to his role as Island Supervisor of the National Wurker's Union. He, been educated at the London School of Economics and was deeply influenced by Harold Laski's socialist political and economic prescriptions 'for the emerging colonial nations."

The leader of the governing JLP administration was Hugh Sheurer. Shearer had been a career trade unionist and politician who becamc president of the Bustamante. Industrial Trade union after Bustamante's - death. Edward Seaģa a Harvara educated Jamaican of Lebanese immigrani parentage, repliaced Shearer as leader of the JLP in 1974.'

"... Under the JLP administration, from 1967 to 1972, econumic gributh continued but positive economic growth was insufficient te win the JLP unprecedented third term in office. Issues relating to the unequal distribution of wealth and corruption in government caused the exception to the major accepted proposition that voters support the incumbent party in prosperous times, and vote against it in periods of. economic decline.

\section{(i) The $1972 \cdot$ Elections}

Problems relating to income distribution and low levels of welfare among the mass of the population were inherent when the JLP 
came to power in 1962. However, these problems increased in scale over the party's ten years in office and no policies had been forthcomming to reduce them. Between 1962 and 1972," for example, unemployment was at its highest level at approximately 25 percent, and in the urban area it had risen to approximately 30 percent of the available - labour force. Of those who were employed, 80 percent earned less than J $\$ 20$ weekly. 2

A primary consequence of high unemployment, was a drastic rise in violent crime against property owners. The government's "attempts to resolve the problem of crime through tough "law and order" prescriptions served only to' "increase the maquitude of social oppression within the poorer layers of the urban social strucfture." 3

In stark contrast to the overcrowded, insanitary, poor and deteriorating physical environment in which the mass of the population eked out an existence, was the growing affluence of the middle and upper strata of the society. This affluence was overtly, expressed in the, 1. display of conspicuous consumption; the impressive growth of modern bưildings; of middle income housing and suburbain shopping centres and of luxury motor car ownership, by the privileged minority. Such - obvious displays of affiuence served to promote rising expectations by the poor for better material conditions, through appropriate government initiatives. The government, however, produced only meagre resource allocations for social programs. Scarce funding, waste and inefficiency in the implementation of programs served.only to create bottlenecks. within the major public services, such as health, education and plousing. These problems were further exacerbated by uncontrolled and r pid population concentration in the urban areas, which inevitably. added to the 
'social frustration of the poorer classes.

Although the overall income and productivity rates seemed impressive, the sectors of the economy, such as export and dumestic agriculture, which employed the. largest sectors of the labour farce, were in a state of relative stagnation.

One index of the degree of social discontent was the overwhelming desire of the population to emigrate to the United States, Candur or Great Britain. In a 1970 survey conducted by Carl Stone, ${ }^{4}$ papular response indicated that, "were such channels of emigration to be opened up, not'more than 20 percent of Jamaica's population would remain within the society:"

The single chạracteristic about the JLP government most of tcin mentioned by survey respondents ${ }^{5}$ during the 1972 election campaign, wis . corruption at its higher levels: The JLP had sought to maintain its śupport by maximizing the dfstribution of welfare, employment and income through the state alonis strict lines of patronage and exclusive partisun preferences. The incvitable result was the crosion of normal bureaucratic: procedures and control over corruption, and an increase in inefficiency and "waste. 6

Rumours of corruption and mismanagement at.all levels of the JLP administration greatly intensified by the end of the 1960's, creating one of the major problem issues in the JLP's bid for re-olection.

The assumption that each interest group seeks to mazimize its economic interests within the limits. of its perception of power and bargaining position, held true in the 1972 campaign. However, accéss to and the distribution of wealth - although a major factor - was not the only issue determining alignments, coalitions and antagonisms. Previous $\therefore \quad 7$ 
to the election, the various class and related interest groups were well represented in the broad class bases, of both parties. However, by 1972, a combination of economic and moral issues produced a notable fealignment of class group support.

The manufacturing and commercial sectors, which traditionally supported the JLP, were resentful of its "Jamaicanization" policy, which was an attempt by the government to play a more influential role in monitoring and regulating the economy. The policy sought to nationalize areas, of the financial sector of the economy and public utilities, which were privately owned.? This business elite, which had traditionally. supported the JLP were resentful of its nationalization and taxation policies, which were viewed as threatening to their interests: As a result they generously financed the PNP's campaign. 8

The JLP' also managed to alienate the Church (a strong moral . influence in Jamaican politics), by resisting their protests against the introduction of a state-run national Iottery. The churches subsequently joined forces with the anti-JLP movement and secured a, victōy on this issue.

The government, was also on the recejving end of pressure group protest against its refusal to re-open enumeration of voters to enfranchise 60,000 young voters who 'were not registered by 1972, because of the time that elapsed between the 1969 enumeration and the 1972. election. The opposition PNP identified with this issue and related it to broader questions of the inefficiency of the voter registration system, and accused the JLP of fraud in the compilation of the voters " 1ists, and the gerrymandering of constituency boundaries. 9

Finaliy, an overwhelming proportion of the lower classes did 
not see themselves as better of in relation to the growing prosperity of the upper and middle classes. They enthusiastically rasponded to Manley's election slogan "Better Must, Come!"

'The social conditions, mood for' change, conflicts and issucs, set the stage for the campaign strategies and tactics of both partics. The PNP focussed its campaign on the social and conomic problems of the lower strata of society. It mphasized the JLP's failure to. adequately deal with ungmployment; housing for the poor; luwincomes for wage earners and farmers; increasing crimes of viulence; need for roads, water and other infirastructure. (especially in the rurul areds); and the level of poverty amidst plenty. However, while condeming the, JLP for its ineffectiveness in addressing these problems, the PNP "made no attempt to suggest [at this time] exac $A$ how these probloms - where to be tackled programaticaliy." 10

The JLP's response was to justify its ten years y of 1 co by quoting details of improvements in welfare services, and tho cconumic and social progress achieved in this period. On this basis the Jil'. sought suppqrt for a renewed term of office.

The PNP also attempted to cultivate' a new political image arounds the themes of participatory democraucy youth, involvement in politicir life, and civil liberties and social justice. Accoraing to stono' "rhe image was characterized by a strong sense of 'populist' sentiments that played on the feelings of alienation, powerlessness and mass aputhy within the electorate." 11 stone described "popuism as, 12 . .

- $\therefore$ a political téndency which seeks' ta elevate and raise the status, power, and interests of those social groups that are located at tre bottom end of a sociai hierarohy, and to assalult and attack interests and yroups that are highly placed"at 
the upper end of the social hierarchy. The populist political tendency is therefore 'redistributive' in its focus, seeking to resolve social conflicts, cleavages and tensions by policies, programs, ideologies and`symbols geared to elevate the powers ant interests of the lower strata at the expense of the privileged strata.

In this election, however, Manley rufrained from identifyung the upper classes as the "class enemy" within a consistent ideology of class struggle. Rather, when he spoke of the unity of the suffering masses which was needed to "break the bonds of oppression," the oppressors to whom he referfed were the corrupt bureaucrats and politicians, not the indigenous upper class, nor foreign capitalists. ${ }^{13}$ . Both parties supported increasing the power of. Jamaicans over cconomic enterprises, jet foreign capitalists were not the target of political campaigp propoganda. "The PNP supported a policy of "Economic Nat lonalizdtion" whlch was not radically different from the JLp's "Jamaicanization" "Dolicy. A though cconomic nationalization recelved ".

very little attention during the campargn, to the upper and middle capitalists classes it suggested a chance to control the economy, with fewer foreign interests. ${ }^{14}$

Manlcy's overtly populist appeal; which deployed such catch

$\therefore$ phrasos as "Better Must Come?" and "Power to the people!" struck certain emotional and ideological chords in the popular consciousness of the Jamaican voters. No attempts were made to explain concrete 'policies to the Pargely illiterate voters. Instead Manley appealed to the normative desires, values and expectations of tho electorate, rather than explaining the actual implications of these promises $\therefore$ or their basis in sound economic analysis. Many were convinced by this rhetoric that his ieadership could achieve both greater social justice 
and continued economic growth. Thus the effective political aryumequ in 1972 was an ideological one.

Although populist politics was pioneered by the jle under" Bustamante, Michael Mantey was the first leader to make Jamuliculi:i fonl that they could control their country's destiny and significantly. restructure the economy and social system that they had Inheriled from colonial rule. His campaign promises and his skillful publle relallums, once in office, led to widespread expectiations of yrat improvemonts. .

The 1972 election was a major landmark an Jamuican hisitory. I'he: PNP, under Manley's charismatic leadersinip, was swept to power with a thirteen-point margin over, the incumbents in the election roturns, wilh the PNP yaining thirty-seven of the fifty parliamentary scals.

The early yoars of the PNP government brought about a number of reforms which marked important changes in Jamaica's dorfestic policy. 1r, New social programs included an adult iiteracy projiram (JwhaL) and free secondary education. The antiquated Master and Servant ladw was abolished, and new legislation involving a minimum wayc law and two months paid maternity leave was introduced, along with more generuus bargaining rights for workers. In land reform, forty-five thousidid acres of land were leased to 23,000 small farmers under Projest Land Lease, and sugar cooperatives were established. A Special Employment. Program (SEP) was also set up to provide work for the chronicully unemployed. The government also nationalized - with compensution, the foreign owned electricity, telephone and bus companies. As a result of these programs, the public sector grew steadily." both in expenditure and in direct employment, and in order to finance them, the government reformed the taxation system by increasing rates 
on certain buxury items, and by changing the basis of the property tast. 16 .

It was nut ic howdver, before the inflationary yiral of 1973 : and the jencrulized world recession in the industrialized economies; 0 severely dislocuted the PNP's reform programs. Drastic price increases In riw materiuls and mactinery; the eratic flyctuations in supplies, and the simry rise in the interest rates charyed by foreign banks, all combined to curtai forvestments and the expansion of employment. The import bilil for oil alone, which próvided ge percent of Jamaica's commercial energy, rocketed from J\$50 millicg itl 1973, to J\$180 million. one year later. 17

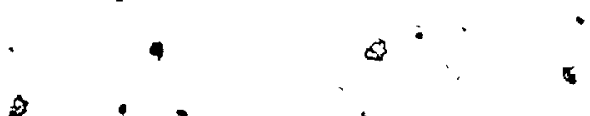 \\ (ii) The Ideology of Democratic Socialism}

The social reforths of the PNP goverpment gaivianized the pood scctors of the society and heightened their expectations of greater social and economic benefițs. This, accoording the Beckford and witter, "sct the stage that forced the party to articulate a "Democratic "socialist" Ideology in $1974 . " 18$ External events, relating to iiberation struggles elsewhere also provided further stimulus to the growing inti-imperialist sentiment of the party. Democratic socialism became

- the ideology through which the PNP's populist reform and aritaimperialist sentiments could be articuatated:

- In early 2974, Michael Manley's book, The Politics of Charige 19 was published, providing a blueprint for the social democratic transformation of Jamaica. In the introduction, Manley identified the $\because \because$ category of politicgr leaders to which he belonged as the "idealists who seek to arrange fundamental change in society." Ho wrote, 


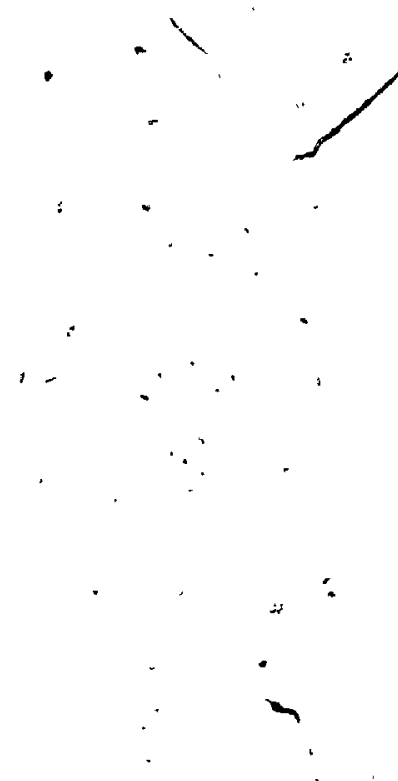

The idealists begin by rejecting existing social relationships and proceed to construct a model of how they think society should be urdered. They are concerned with the basic changes that are necessary to effect the transformation from ons state to the other. . . Like all political leaders who belong to the idfalistic strcam, I have found myself constaneIY in the presence of a personal, moral imperative: How to isolate a single, central thesis of belief from tho welter of conflicting moral catejories. Of course une must be concerned with equitable distribution of wealth, with social stability and order, with individual 11 berty. But always the suggestiun has lurked that these cutegorics are in conflict and that the political idealist must make a choice. I reject this notion . .. There has energed for me a single touchstone : ... the notion of equality.

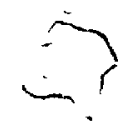

Centras themes of his work were cquality, social justife and the politics of participation. Manley also put forward a crilijue of

- $\because$ capitalism and imperialism, and the question of nationat self-rolianco as a basic altornative.

This ldeological stance clearly ingicated that the pN"'s approach to governing would involve the building of an entire new suxiul reality : described in chapter one as architectanic. Ilis problem inherent in this approach is often evident in the type ar fyouls the govezment sets for the country and the means sought to, ublain them. However. "If the government. is to perform its proper role, ils guils must not onqy reflect a proper sense of what needs to be done, but also what can realistically be aceomplished. 'This, requires a reliabie sense, of balance between what is normatively desired and what is objectively possible. The joals set by the PNP government for the achictemont of democratic socialism, provides the first indication of its prospects for striking this crucial balance.

Throughout its political mandate, the PNP sought to define 
itse-1f as' a vanguard party, "charged with a mandate to advance and. decelerate socialist-democratization by extonding greater popular control over alf the domains of power in the society." 20 "The party defined its yodis in the following central arcas: ${ }^{21}$

1. Broadening tho base of ownership of capital and promoting yreater worker participation land influence over the prodLuction process.

2. Establishing greater internal dempcracy in its internal party machinery. '

3. Deepening and bradening political awareness through programs of mass political education and politicization, using the the ideology of democratic ialism as the basis for this mobilization.

4. Democratizing the political process at the local level by - expanding local government autonomy and creating new institutional forms, such as grassroots community councils, as, the vehicles through which to articulate local demairacy.

5. Democratizing the educational system by bringing students and workers into the joint management of these institutions.

6. Bringing citizens into the machinery of Law enforcemint

- through Home Guards that would work alongiside the police ins fighting crime on the local commity level.

7. Promoting popular participation in the processes of planning and economic decision-making.

8. Promoting forms of community and popular ownership of land and agricultural production.

-9. Promoting social legislation designed to raise the level. Qf equality realized by disadvantaged groups.

10. Estabíshing popular control over the mass media, using state ownership as a mechanism through which to move to more broadly based ownerșhip.

11. Removing the restrictions on literature of a political. character imposed by the earlier JLP government.

12. Engineering basit constitutional changes designed to máke - the fundamental laws of the land more in tune with popular control, of the political system. 


\section{b}

64

13. Isolating the privileged bourgeois ihterosts as ememies of the people and harassing these classes and minority, racial interests as obstacles to progress and exploiters of the massies.

" 14. Extending Government control over the economy and especiully its commanding heights to further the cipuse of fhe :ouplo':
interests.

15. Bringing the party machinery and purty activists into direct involvement wilh the implementatiun or sonsilive areas of public policy.

* It is apparent from this exter sive list that the juveriment wa:i seeking to undertake an extromely comprehensive proxjam of defocratic: socialist reforms. .Given the basic principles which govern' purties in a democratic society - that the right to govern is only fur a 1 imiled period of time, and the probability of losing the next clection is always high - the PNP's Ear-reaching goals for the creatign of a new sociul reality could only be described as overly ambitious.

However, with the 1974 legitimization of democratic socialisin in the political process, a watershed in the histury of Jamaican politics had been reached. For the first time, a clear ideoloxical distincition could be made between the two competing partics. This, accurdiny lu Beckford a'd Witter, marked the brcaking away of what was uip to thon, "nothing more than the politics of .tweedle-dee and tweedle-dum." 22

\section{(iii) Policy Implications}

- On the basis of its idcology, the PNP administration ittompted to chart a course based on a non-aligned, pro-Third World roreign pulicy, and democratic socialism in its domestic economic and social policics. These policies included the following:

1... A Bauxite levy to increàse government revenues and the country's foreign exchange receipts from the 
bauxitc/alumina industry;

2. Eormation of the International Bauxite Association (in which Manley was instrumental);

3. numerous social welfare measures, and

4. raising the level of socialist political consciousness in order to support its policies.

5. On the level of international relations, the government strengthened relations with neighbouring Cuba ;

6. supported the liberation struggles in Southern Africa (including the support for Cuban troops in Angola) and.

7. helped"to fortify the Non-uligned Movement in the struggle for a New International Economic order.

By 1976 the problems of a preponderant 1 y ideological approach to : governing began to be manifested in extremely negative reactions to the yovcrnment's coreign and domestic policiès. 'This proved particularly damaying to the government as the adverse response emanated from those areas of interest which had the greatest influence on the outcome of its policies.

The PNP's foreign policy initiatives invoked'a harsh reaction. - noto only from foreign investors, but also from the state Department of . the United States. The Bauxite levy resulted in a tax rate increase of 480 percent between 1973 . and 1975, which helped to offset the averwhelming increase in the country's imported oil bill. However, the aluminium companies soon responded to the 7.5 percent tax levy, by gradyaly transferring bauxite and alumina production from Jamaica to other countries. "Thus, by 1978, bauxite exports were reduced to 30 percent. 24

In tandem with the aluminum companies, other multinationals also 
curtailed their investments and activities on the isiand. Foreign capital inflows shrank from US\$254 million in 1973 to US $\$ 115$ million in 1975, and in 1976, a net outflow was recorded. 25

In additión, the government-'s close relationship with cuba, and the support of the MPLA in Angola drew harsh response from the United States State Department. "In" 1975, the U.S. Agency for international Development (USAID), turned down Jamaica's request for a US\$25 miliion food grant, refusing to lend additional funds until Jamaica chunged its stance.' By 1976, the American Import-Export Bank dropped Jamaicu's credit rating from a top to a bottom.category. ${ }^{26}$ The United States press also discouraged tourists from coming to the island, thereby undercutting the tourist industry. Between 1974 and 1975, tourism declined by 13 percent, and dropped by an additional 10 percent in 1976.27

On the domestic scene, the Jamaican capitalist classes joined their foreign allies in the anti-government policy offensive. As a result, the Jamaican private sector carried out a general yo-sjow in production, and refused, to undertake new investments. Throughout the remainder of the Manley administration, the capitalist classes also carried out "what amounted to a sustained campaign of slander aguinst the PNP. through its chicf voice, the Daily Glcaner." 28 .

Manley's well-known response to his critics, that there were "five flights to Miami every day" for those who didn't like his policies, was apparently taken more seriously than intended. Many took him up . . on his suggestion and Jamaica suffered the largest exodus of upper and middle class businessmen and professional people in its history. $29^{\circ}$. Along with them went a substantial amount of badly-needed capital. The retaliation of foreign and domestic capitalist interests to 
the initiatives taken by the government on behalf of the poorer classes, incensed the masses, and the PNP launched a national anti-imporialist campaign that fired the spirit of resistance throughout 1976.30

\section{(iv) lhe 1976 Elections}

- Arti-colonialism and anti-imperialism became the central topics. of the 1976 elections. Underlying the diverse issues of the campaign was the common theme of foreign owmership and control of economic enterprises. In a pre-election speech of September 1976, at the National Stadium, Manley reflected, the mood of the majority of Jamaicans when he articulated the view "WE ARE NOT FOR "SALE!"

The JLP opposition was forced to adopt "Nationalism" as its : contending ideology, 31 and concentrated much of its campaign on domestic issues, while courting financial support from the upper classes. 32

The 1976 election was the first in Jamaica in which ideological concerns were prominent in the campaign, and constituted readily perceived differences betwcen the two political parties. In contrast to " the 1967 election, when references to class, anticolonialism and imperialism were rare and peripheral to the campaign, by 1976, these issues were overtly addressed by poiliticians.

In the PNP campaign, under the democratic socialism banner, Manley made ditect reférences to class when he declared "we are committed to raising the standard of living for the most needy in our society."33 It was the first time in any election that an ideological concept really generated mass support.

While the PNP campaigned on its record of social programs and called upon the electorate for a mandate for democratic socialism, the 
JLP campaigned on the economic mismanagement of the guvernment, which had increased the post of living and brought untold hardship to the Jamaican people. 34

Repeatedly the JLP presented socialism as a system in which everyone was uniformly poor. Accordingly, the party pronounced that the path to lower unemployment and lower cost of living was "No More Socialism!" 35 The JLP therefore promised the reinstitution of "economic freedom." 36 The PNP condemned the JLP's formula of free enterprise, and during its campaign, capitalism as a guiding principle was equated with slavery. 37

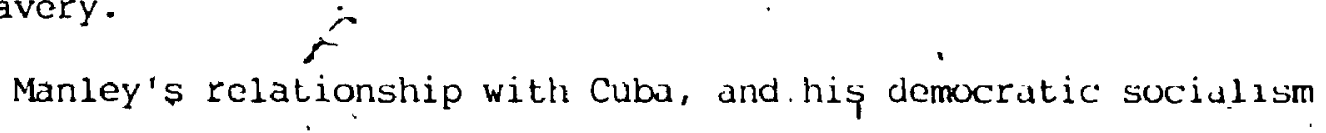
stance combined to make the "Communist Threat" secm a fruitful istuc for the-opposition to exploit. Manley was sensitive to this issuc and repeatedly sought to assure the electorate that Jamaicd would nol "go communist." 38

The election witnessed the turnabout in support coulitions of the parties that had begun in 1972. The stereotype of the PNP as a middle class" party was completely undermined. The JLP was no longer the "poor man's" party, champioring their cause against undefined enemies. The PNP emerged as the party; not only representing the poorest classes, but representing them as the victims of exploitution and uncontrolled capitalism both nationally and globally.

Manley's programs had been designed to help not only the lower working class, but the chronically unemployed, the landless peasants and the domestic workers. Hence democratic socialișm came to be identified with improvements in the lives of the poor, while making the lives of the: upper classes more difficult with higher taxes. 39 
Thus; the government's promotion of a rigid slass bias in favouring the poor over the interests of the wealthier classes, blurred the distipction between the role of a political party, as opposed to the role of government: Whereas a political party may represent particular sections of society, the government, in a.truly democratic system must. endeavour to represent the interest of the population on a whole. Policies which promote rigid class polarization's such as those of the PNP government, heightened conflicts between two equally legitimate' interests. This has particularly damaging consequences in a society such as Jamaica's where major resources are both publicly and privately owned and government policies - based largely on distributive matters, require a skillful balancing of group interests. While the poor expected to be the major beneficiaries of the redistribution policy, much of the resources and means to effectively implement this policy rested with the wealthier classes. A sound government policy would have endeavoured to find rational means of distributing the 'cost' involved in the redistribution process' throughout the entir? society. By alienating the wealthy upper - classes from positive involvement in the process, the PNP government deprived the country of one of the most important sources of effective policy implementation.

Data from polls taken in the Kingston area 40 , showed that the upper and upper middle classes had, for the first time virtually abandoned the PNP: In 1967, 40 percent of the upper class had voted PNP; in 1972 this class gave the party 75 percent of its votes. By 1976, however, only 27 percent voted PNP. The trends for the middle class were similar.' Its support dropped from 81.4 percent in 1972, to' 40.2 percent 1976 . On the other hand, the poorer strata of the lower class all bat abandoned - 1 
the JLP. Oniy 28.4 percent of this class voted JLP in 1976, compared with 57.6 percent in 1967.

Stone's research. 41 on the electorate response to the PNI's ideology of democratic socialism indicates the degreo of rationalo which guided the electorate to renew the PNP's mandate for a secund term. His 1976 findings indicated that,

PNP supporters attached to Democratic Socialism varying meanings, including a commitment. to help the small people against the rich, social justice, and a desire to change society in ways that woyld benefit the poorer classes . . . In short, it was. interpreted in ways very close to the populist support for Bustamante's 'labourism' of the $1930^{\prime}$ 's and 1940's, except that it was informed by a. greater senise of class enemies against the poor and a deeper feeling that social justice required some drastic changes in the society:

$\therefore$ Essentially, Herefore, democratic socialism was taken on its broadest ideological level to mean overall improvements for the poor, and. on that basis, in December 1976, the electorate gave the PNP another resounding mandate for another term in office. The PNP swept to victory winning 47 of the 60 seats and 56.8 percent of the pophlar vote. The leader of the opposition, Edward Seaga called the resuits, - "a very clear and decisive victory," and the selection of "one ideology over the other." 42

The years following the 1976 elections came to be known dis the "IMF Years," as the government's involvement with the International. Monetary Fund greatly influenced, not only the direction of future policies, but also the future of the ldeology of democratic socialism in Jamaican pólitics.

Riding the, wave of an overwhelming-election mandate, the PNP rejected a proposed loan package from the IMF in January 1977, becausid. 
it felt there were too many strings attached which would jeopardize the social programs and undermine the credibility of the party's ideological stance. Instead, in order to meet the worsening economic crisis, the PNP announced a second reform program, the Emergency Production Plan, which strongly omphasized the principle of self-reliance. In addition,

- higher taxes were imposed on the rich, foreign banks were nationalized (with compensation), restrictions were placed on foreign texchange, and a State Trading Corporation was set up to regulate foreign trade. ${ }^{4} 3$

The choice between an unpopular (though rational) pollcy,. and another extremely, popular (but irrational) policy, is a basic problem in competitive democratic politics, insofar as it relates to polícy determination and electoral expediency. Faced with the choice between an IMF loan with its attendant adjustment policies, and the popular : social programs, the government' predictably chose the option which pleased the electorate. To choose the unpopular IMF loan package would have been the more rational economic decision. However, its adjustment policiles demand harsh short-term sacrifices in order to achicve long-tegh results. The alternative decision, in favour of the more popular social programs, was consequently. determined by. political expediency, rather than sound economic judgement. Although - it is desirable for a government to strike a reasonable baiance between electoral popularity and sound policies, this would require a major effort on its part to create a better appreciation in the minds of the electorate of what is realistically possible. However, in a highly competitive political system, such,as exists in Jamaica, this is exceedingly difficult, particularly in circumstances where popular policies, founded . on strong ideological promises, raise expectations for immediate results. 


\section{ras}

Hence, a party is often forced to determine' policics almust entircly on the grounds of electoral expediency, if it is to remain a viable force in the contention for power. In the case of the PNP yoverument's. decision in 1977, however," the economic results overwhelmed the politicil means of problem-solving.

The capitalist classes responded to the new policy initiulives with more production cutbacks and layofis, while tro ecopomic silumlion. reached crisis proportions. The government eventually backed dowll. and. accepted the terms of an IMF standby loan of US\$7a milition tu case thr: worsening balance of payments situation. The loan, ayreement itwluded a devaluation of 40 percent of the Jamaican currency, with a two-tier exchange rate that maintained the old rate for certain basic youds. By December 1977, however, the government failed to meet the loan conditions and the agreement was suspended. Now negotiations were prolonged until May 1978, by which time the country was"on the orink of defaultiny on its foreign debts.. The new agreement, for us $\$ 240 \mathrm{mi} 11$ ion over three years, under the Extended Fund Facility, 44 entailed unotiler massive series of devaluations; wage restraints, and tight budget 'management, to restrict expenditures and greater participation or govern-". ment in the economy, along with a projected $\$ 180$ million in now taxis. 45 " The harsh IMF conditions initiated a process that generated une of the most severe periods of economic hardships Jamaica had nver experienced. It also cost the PNP a dramatic decline in popular support, as the IMF agreement with its subsequent impact on the welfare of the poor was perceived by many as a demoralizing retreat from thic democratic socialist stance of anti-imperialism and self-reliance. "According tö". Fitaroy Ambursley, 46 . 
The contradiction in the PNP reyime became

increasingly apparent as Manley continued to

make 'anti-imperialist' speeches at international

forums, while at home he presided over a mas ive reduction in working class living standards.

In the first year of the IMF agreement alone, there was a

40 percent increase in the cost of living, and a 25 percent cut in the roal wayes of the employed. 17

(v) Implications for Develoument

The PNP's clyht years of democratic sochalism demonstrated the basic difference between the plausible and possible. 'Its attame to create a new social reality resulted in dristic changes in the economic: social, political and ideological foundations of the society, prociacing adverse results. Given the powerful constraints imposed on the govern- : ment, such as limited resources, structural malpdjustment, uncontroliable external influences and unpredictable events, the policies of the PNP government unreasonably attempted to accomplish too much, too soon. The implications for Jamaica's economic and soclal develiopment were most severe.

After eight years, democratic socialism had resulted in a rail in real income of 25 percent, while the cost of living rose 320 percent over the period. In 1980, net foreign exchange roverues storn! at minus $J \$ 900$ million, ( $J \$ 1=U S \$ 1.77$ in 1980$)$, representing a fall of1.014 percent since 1972. Real investment fell by 65 percent. Unemployment rose to 31 percent in October 1979. 48 The foreign debt was J\$3,147 million - a 47 percent increase since 1872. 49 "Between.1973 and 1980, the GDP plummeted by $18.3^{\prime}$ percent ${ }^{50}$ and Eactories ran at only 30 percent of capacity. 51 


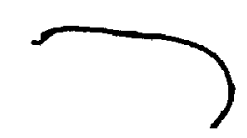

The bauxite levy did result in a substantial morease in iovernment revenues, rang from J24.51 million in 1973 to J\$185 inilizon in 1977. However, the counter-offonsive mounted by the dluminum iumpumbs

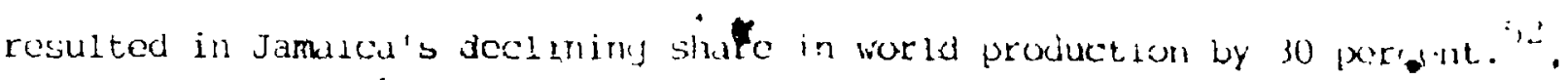

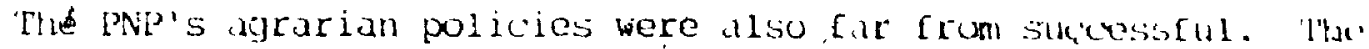

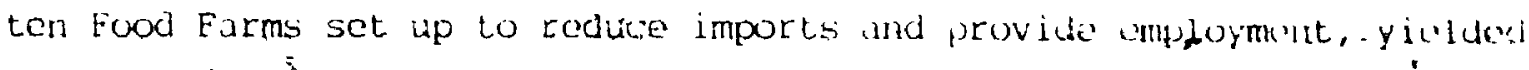

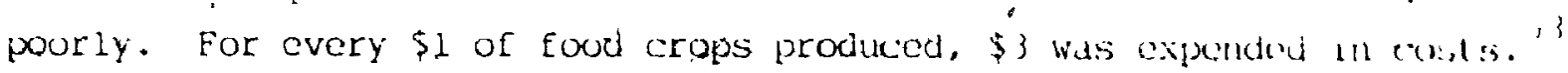
Poor results were attributed to lubour indiscipline, polloll.n intimuation of technocratic controlis, the overmuning of projech: Lheowh party patronage fuvours, and thert of crops. je' Hy 1976, the proxim lidu lost nearly $\$ 3.3$ million and had to be abandoned. Plugued by simil it" is problems, the horticr-run sugar cooperatives suffered a drois in proxuction, to 242,000 tonnes in 1980 - the worst in thirty-rive yeur:, whd the inciustry had an accumulated dont of US\$67 mi1110n.

At a cost of miklions of dollars, the land reform proxtem,

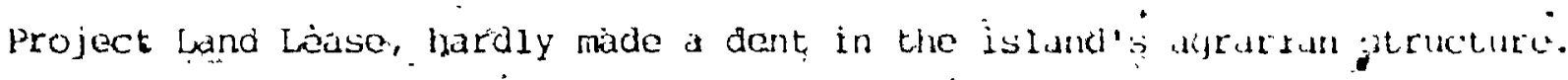
Eivg landowners weréable to circumvent the program ugrough 1 chusio which al lowed them to submit "development plans": if tindy did not wlisi idilo land.; on their estates to be taken overby jovornnkent. As a result, unly 24,700) acres of the 128,731 acres adjudjed to be idra by the laind Development. Wred Utilization Comission report of 1978 , vas availabie for foverumeit açquisition. 56

As the mood of the country shifted from majurity supajort for the PNP to majority support for the JLP opposition parly, a number of proframs became casualties - were abandoned, or scaicd down due to lack of strony public support. These included, worker participation, constitutionsl change, local jovernment reform, democtatization of exucutiondil 



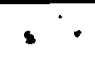

'have meant. avoidance of further adjustmonts rejuested by the Inf - of $\therefore$ considerable importance in a diffifult tlection yeur. llowever, it also - meant denying the country of essential forcign exchunge. In a fillal bid to rescue popular support far democratic. socialism on the dicution platform, the PNP National Executive Committee animously approved

- abandoning tho IMF (at least in prncipio). However, erforts iu. obtain substitute funds from other sources met with powr resulls, and by mid-1980. Jamaica was Eacing bankrupcy, desparately tryiá, to.

- jot tirough the montins until the october elections.

(vi) Eencral Observations =

The politics of democratic socialism introduced a new dimension lu Jamaican polftics, wich produced several conflicting and unanticipaled results. The ideology had tapped a déep popular aspiration for an and to . the old order and the creation of a nevi und just society. However, lire conceptualization of the ideology and the implementation of the policists it i implied proved to be its nomegis.

Major problems in the areas or limited Lechuocratil: ikillis and intellectual resourses; lack of discipline moms party cudros; ramint

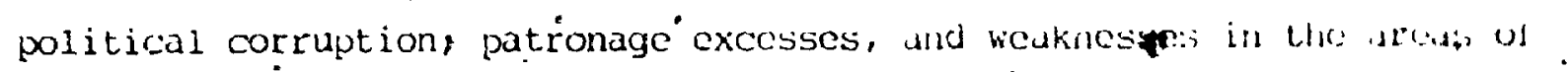
planning, 61 all contributed to the problems, encountered in tio implemm atıon of poricies. However, it was in the area of conceptualizadien that

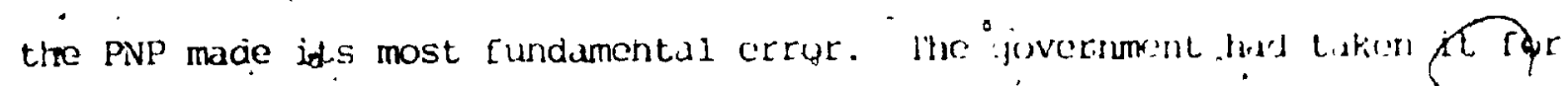

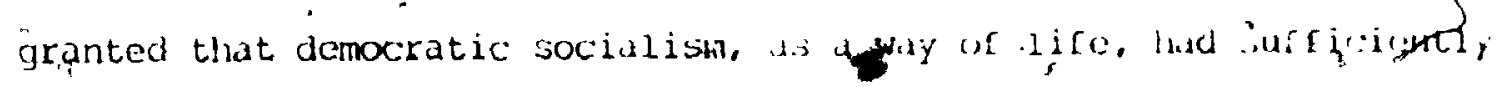

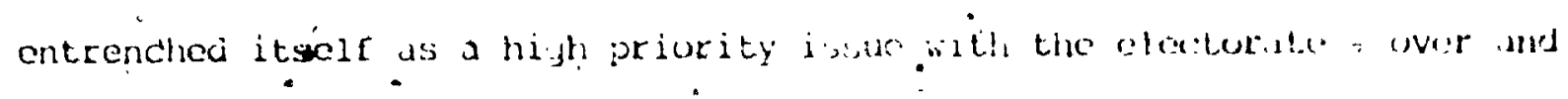
above the traditional expectations of malerial wolfire ionefila. rublie: •

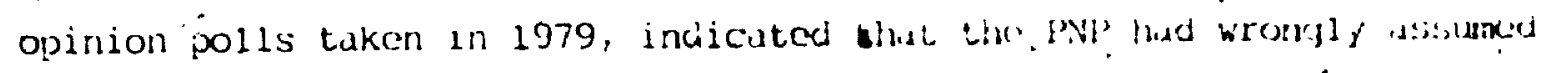


Lhat a basic' snift had taken place, in political falues, whereby ideological principles per se would elicit strons public support, independent of its perceived benefits to the econony.

According to stpne's research, ${ }^{62}$ the policies for which the electorate gave the PNP the most credit were the protection of tenants, cyual rights for women, and the minimum wage, which are all social legislfitive areas with anticipated material benefits. "There was a ." conspicuous lack of credit given to any of the democratization initiatives" listed earlier.

$\therefore$ Añother unanticipated result of the PNP's populist icieology, was the way in which the principle of "equality" was perceived. There emerged a tyeneral association by the ". poorer classes of all forms of authority with oppressive manipulation. Ihis led to a geneiral weakening . of authority systems in schools, productive enterprises, public institutions, and politicil life. As.a result, there was an increasiry rosort to violence and intimidation as the ultimate means of resolvirig conflicts: Hence, "democratization efforts encourayod anarchic: tondencies where weik authority systerle provailed." 63

'The PNy was unable to find a way to synthesize jopulist politics

- with stromy authority eloments, ano social instability was adder to. the jrowing list of government problems. Stone oisserved that ${ }^{64}$ the

Yijh levels of crime, countered by militarizcd pulice vigilance, that spilled over into, the sbuse of polier and police harassment of poor communities, projected the government in the same role as the former. JLP yovernment in its reaction to political radicalism in circumstancas of increasing crime in 1972 .

Findly, one important political aspect of the PNil's social denucratic progrum wis its promotion of popular politicas purticipatiqu. 
This had a positive impact on tice mobilization of public opinion and the erosion of partisan" loyaltics. During tho 1970's; Jamaicanis Lecumi more sensitive to public opinior, issues, and lass inclined to vote according to blind partisan loyalties. "More than at any time in the country':; hisțory, citizens talled politics, assessed issues, read pulitilid commentaries in the newspapers, and took positions on rontruver:il, l issues.". 65

This trend worked against the PNP in the 1989 ole tidm, whun * vocal anti-government groups and interests were able to u.jo liberal principles of free speecil; freedom of assuciution and froodum, (1) arbitrary \$tate power to nount damaging crficismis wainst the t'Ne' goyerument.

By October 1980, tine Piv' was voled out of of fice by the intme sectors of the "exploited" lower class whosc plight it ihi pronisud tu change forever. The massive decline in the matorial living stundurd: of the poorer classes had set tire stage for tine mass disirfortion rrom the party: "By early 1979, it had become quite apiarent thut the :iox:ial

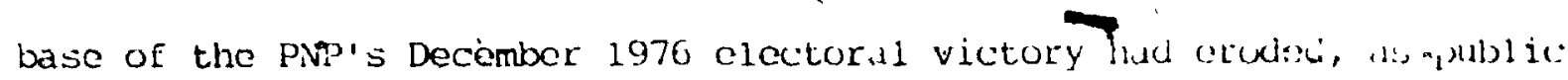

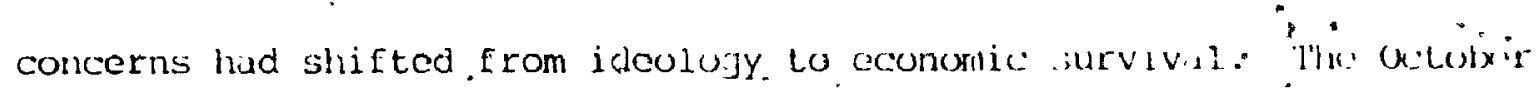

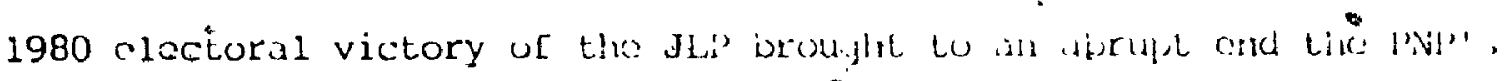
eijilt your exporiment in renocratic sorialitim. 
1 John D. Forbes, Jamaica: Managing Political and Economic Chanje, Wasinington: American Enterprise Institute, for Public iolicy Rescarch, 1985, P. 15.

2 Rulph:Gonsalvos, "lihe Rodney Affair," Caribbean Quarterly. No. Soptemiber 1979, p. 1 .

3 Carl Stone, Elcctoral Bohaviour and Public Opinion in Jamaica, kingston, Jumida: Institute for Social and Economic Research, 1974, [D) $15-16$.

1 Hid: p. 16

5 seo survey conducted by Anita M. Waters, Race, Class and lolitical Symaxuls, New Jeßsey, U.S.A.: Transuction Books, 1985, p. 108.

o Stone, 1974, pp. 16-17.

7 Ibid. p. 17

8. Furbes, $1985 ; ?: 210$.

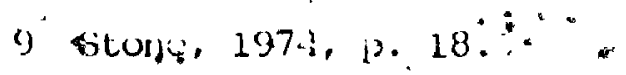

10 Lvid. p. 18

il Ibia. p.i19.

- 12 Cars Stone, "Denocracy and Socialism in Jamaica: 1972-1979,"-" $1 n$ The Newer Curibbean: Decolunization, Democracy and Develo,ment, cd. Pajet llenry and Carl Stone, Philadelplita: Institute for the Study or lluman Lisuas, 1983, p. 236.

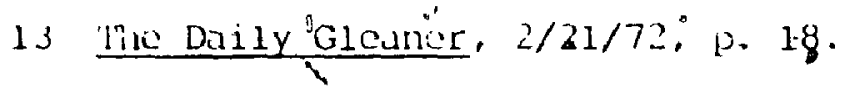

1.1 Waturs, 1985 , 21) $117-120$.

15 Goorje Beckford and Michael witter, Small Gardem, Bitter Weed. kinyston, Jamtica: University school of printing, 1980.

10 soe initors, 1985, p. 143, and Forbes, 1985, pp. 18-19.

.17 A.p. Maingot, "The Difficult Path to Socialism in the Englishspeaking Caribloan," in Capitalism and the State in U.S. -Latin American Relations, of. R.R. Fayen, California: Stanford University Press, 1979, Pp. 254-301.

18 Becliford and witter, 1980, p. 87.

19 Michael itundey, The Politics of Cilunijo: a Jamaican Testament, Wundon: andre Deutsch, 1974, p. 15-17. 
Chapter' II I

20 stone, 1983, pp. 243.

21 Ibid. pp. 243-244. (Car1 stone served on the comittes set $u_{i}$ ) - by the government to make recommendations on workar participation in Jamaica, and.was a member of the statutory board cstablished to uverses? the introduction of sugar cooperatives.)

22 Beckford and litter, 1980, p. 87.

23 Ibid. p. 90.

24 S. Keith and R. Girling, "Caribbean Conflict: Jemuica and qik U.S.," NACLA, Vol. 12, No. 3, 1978, p. 29.

25 Norman Girvan, "Swallowing the IMF Medicine in the Seventikn," Development Dialogue, No. 2, 1980, p. 62.

26 Keith and Girling, 1978, p. 31.

27 Ibid." pp. 30-31. see aiso, Michael Manley's Jumuicu: Sitruyill.

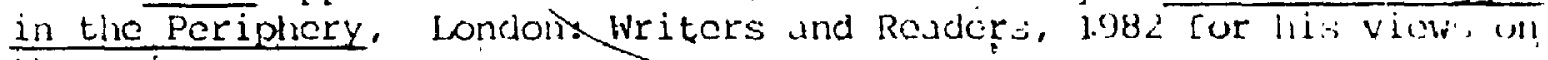
these issues.

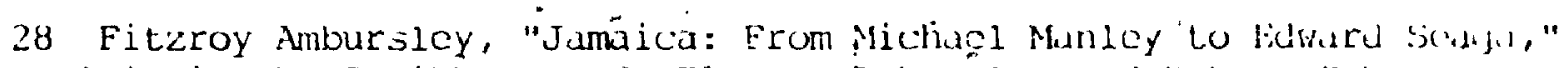
in Crisis in the Caribbean, ed. Fitzroy Anbursicy and linirl Coln, Kingston, Jamaica: lleineminu, 1983, pp: 77-78.

29 Peter L. Berger, "Can the Caribixin doarn from kid.sh Nisin;" . Caribbean Revicu, Vol. XIII, No. 2, S, siny 1981, :2. 7.

30 Beckiord and lititer, 1980, is. 90.

31 IDid. P. 91.

32 Watcrs, 1985 , p. 196

33 Tic Daily Gleancr, $11 / 23 / 70$, p. 2 .

34 Ibid. $11 / 24,76,9.7$ and $11 / 27 / 76$, ;. 21.

35 Ibid. $12 / 2 / 76$, p. 9.

36 Ibid. $12 / 14 / 76,20$

.37 Ibia. 12/13/76, 2:2.

38 Ibid. 12/14/76, 2.1 , and the Wockly Giedner, 12/21/76, p. 2.

39 Waters, 1985, ?. 196:" 
Cha,pter II I

$40^{\circ}$ Caril Stone, Public Opinion Pollis, The Daily Glaaner, 6/8/80, 'p. 7.

11 Ibid. $11 / 21 / 76$.

12 Tilc Daily GlecineE, 12/16/76, p.1.

43 . Nabursley, 1983, 2P. 84-85.

$f_{1} F_{1}$ Forbes, 1985, p. 27.

45 iseciford ansi Wittor, 1980, p. 95."

.16 Anisursicy, $1983,2.85$.

i7 Beckford aik bitter, 1980, p. 95.

18̀ Amisursiey, 1983, 23. 35-86.

is The Heckly Glumar, 10/29/80 and $12 / 16 / 81$.

i) Ibici. $9 / 30 / 31$.

51 Ine Pinancid Timos, 11/5/30.

I2 Koilh and Girling, 1973, 2. 21.

53 soe $A$. Crant, "The Land Reform Program of Damocratic Sucialisil,"

- Socialism, Kingstori, Jamaica: The Workers Party of Janaica, Vol. $\because$ No.i. $1977.25 .-17,61$.

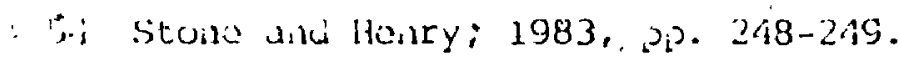

5.) line Filluncidt Timosi, 9/10/80.

50 l". Marrigt, "ilha Int and tire Strajgle for Lanci," Socizlism, vol. 6 No. 2, 1979, 2s. 48-57.

57 Stuno and Honsy: 1933, p. 249.

58 Forba, 1985, ip. 27.

59 Stone and Hanry, 1983, 20. 251-252.

60 Fories, $1985, \circ .28$.

61 Stone and Henry, Pi,. 24j-2\&6.

62 Ibid. P. 253. 
. 1

Chapter III

63 Ibid. p. 251
64 Ibid. p. 251.
65 Ibid. . 251

63 Ibid. p. 251
64 Ibid. p. 251.
65 Ibid. . 251

63 Ibid. p. 251
64 Ibid. p. 251.
65 Ibid. . 251

$\infty$

42

- 
CHAPTER IV

THE JLP YEARS : $1980-1983$

The proposition that voters tend to support a party in prosperous times, and to vote against it in periods of economic decline held

- Erue in the $1980^{\circ}$ elections. Throughơt the campaign, economic conditions proved to be the dominant "concern of Jamaicans. Although ideology played a larye role in the electioneering strategy of both parties, in the public ranking of irportant issues it placed a poor third below the economy, and social and political violence."

The economic and social problems facing the country prior to the 1980 elections were, severe. By October of 1980, the country was virtually bankrupt, with only enough foreign exchange for two day's imports. 2 'Traditional agricultural exports were at their lowest ebb in decudos; bauxite production had fallen arastically, and manufacturing .. stiood at 40 percent of installed capacity. The tourist industry was also badly hurt by reports of political violence on the island. 3 : lublicly -owned enterprises were losiny massive amounts of money. In addition to these problems, the illegal marijuana trade, which had become une of the island's most valuable source of hard currency, wat spreading corrupcion and violence into many sectors of the society. The hedvy reduction in public spending towards the end of the 1970 's had proved costly for the society in several ways. It created a massive increase in the cost of. consumer goods, which were both scarce and in high demand, while causing the elimination of food subsidies whith might have helped to ease the burden for the poorer consumers. Roads, schools, hospitals and other public services deteriorated badly. 
and public utiigties of ten broke down for lack of spare parts and proper maintenance..

The government's social reform programs had all but disappeared. Illiteracy was rising, and accoprding to reports in the Jamaican prass, more than 50 percent of those leaving elementary sctool by mid-1980 could neither read-nor write. At the same time, the emigration or essential professional and managerial skills left the country in shorl. -supply, while 30 percent of the labour force remained unempluyed. Virtually every area of the economy, and society was beset with prublems which the next elected government would inherit.

\section{(i) The 1980 Elections}

: Apart from the massive deterioration, of the conomy, far of. communism provè to be the second highest topic on lhe campai'jn. a.jenda. Towards the efid of the $1970^{\prime} \mathrm{s}$, the PNP was divided between a majority. of moderate "keft-of-center" members, who respected the democritic rulus of two-party patriamentary politics, and a smali but visible and very vocal minority of Marxist-Leninist supporters. This group was led by the PNP's General Secretary, D.K. Duncan, who favoured a one-party . - system. Combined with the open support of the Jamaicin, communist party, (The Workers Party of Jamaica), and the PNp's avowed support of Cuba and other socialist countries, the-incegusinyly radical rhetoric: emanating from the purty by late 1979 peyan to alarm the extromely anti- . communist jamaican electorate. The issue of communism, which. had pruvenn ". to be unproductive for the opposition JLP's campaign in 1976, worked. ayainst the PNP in 1980 and was again pursued by the Jiw with gyen. yreater vigor. Thus, the campaign struteyies of both pxirties fercum: 
focused on idealog and economic policies. The JLP accused the PNP of pro- communist leanings, and the PNP accused the JLP. of pro-imperialist tendencies. The virtues of a free enterprise economy over a redistributive socialist economy were widely debated. Thus the PNP urged the clectorate to "Stand Firm" behind democratic socialism, and the JLP promised "Deliverance" Erom it. 4

As in the previous election campaign, the PNP defended its record of efforts to improve the Iot of the majority, on the basis of its various social programs and legislation. The party also blamed its economic problems on the world economy and the machinátions of OPEC and the International Monetary Fund. In addition, it accused the CIA and the 'local capitalist cliques of being agents of imperialism who were bent on political and economic sabotage. ${ }^{\circ}$ 'This provided the basis around which to build its militant anti-imperialist posture:

The JLP campaign also centered on the same basic issues raised in 1976: It accused the PNP of reckless mismanagement of the economy, and equated democratic socialism with poverty and suffering. ThP was accused of flirtin with communism; of selling out. Jamaica's. interests to cuba and other communist aliies, and of paying too much attention to foreign policies while neglecting the poor at home. 6

In response to the P̂R's posture of anti-imperialism, the.JLP Idvocated closer ties with the United States and other Western capitalist interests. It expressed a commitment to "free enterprise," which would encouraje foreign investment. This, according to the opposition leader, Edward Șeaja, "would increase opportunities for the poor by creating femployment. " 7

- Throughout the campaign the JLP projected itself as a party fully 


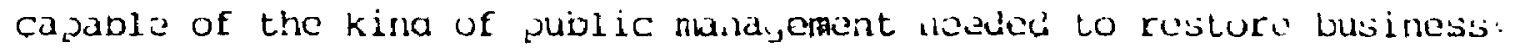

confidence and bring about economic'recovery. It portirayed suxialion as reading to communism arid the loss of julitical fredaom, which it

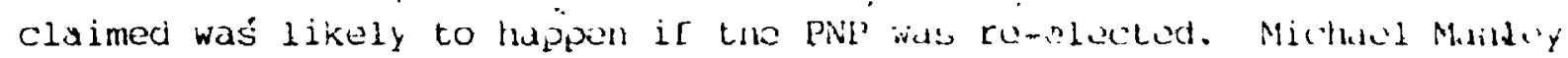

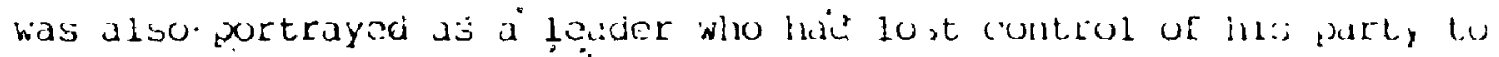
Cubuns and local communist radicals.

L.

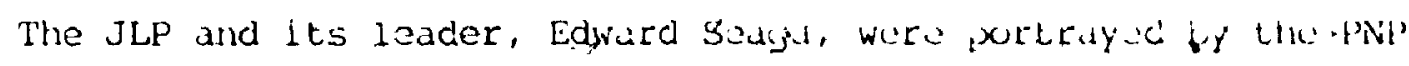

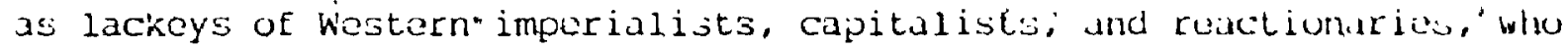
threatened to furn back pró,ressive jeople-oriatited pulitias if ilocku

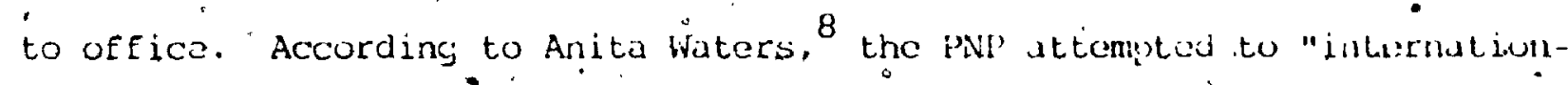

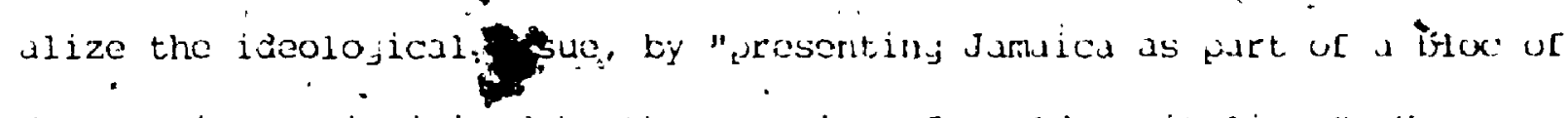
poor nations, victimized by tile vagaries pr. world capitulista." Howrvir, Lat" PNP overestimated the èiectorate's jrasij of fis senuincy theory. Ili: , postura on anti-ipperialism did not penetrate the consciubsness of must Jamaicans, who had many friends. und relativgs in the United States, - Britain and Canada-who were doing wekl tinancially." Au uverwhelmu, number of Jamaicans also uspled to similar upportunteles for ma rition.

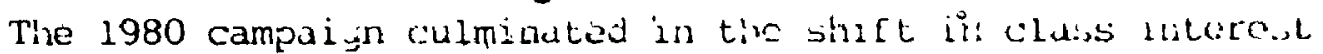
- support which had become cuite noticable by 1976. lhe Pivl"s stull Ld - democratic socialism and posulist politics in 197.1, iud started roalignment from a reasonably balanced mulli-class support teivirds un! increasingiy cluss-based party"system. By 1980, hovevur, wili lik: exception of die-hard adberents, the PNB lust most wf it.s Uisper and midale class supporters to the JL. These classes were woth rearful of communism and the prispect of further comomic deteribracion under tine PNP. The PNP alsc lost nuch, ground with the betereder stedta of thy

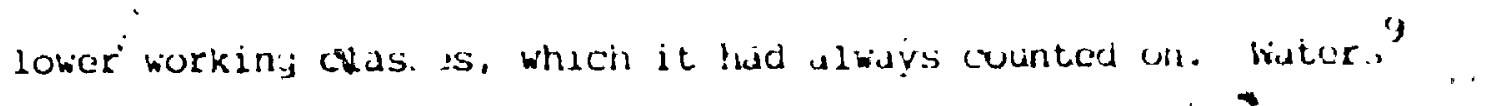




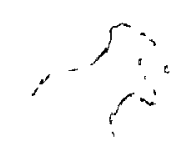

attributes this decline to the escalating prices of luxury items which this class either aspired to or had obtained, (such as cars and modern ixousehold applíances), buţ were not able to surdhase or maintain because of high taxes on juxury items, and such itams as spare parts, or on jasoline and electricity to run them. The lass of support of the better-of working class yroups, combined with that of the midale and upper clässes, made a tremendous difference to the PNEat the polis.

The poorest strata of the society also defected from the PNP. They were demoralized by persistẻnt economic hardships and listened

* attentively to the JLP's campaign promise of economic recovery in only thiree years. As in previous elections, the JLP promised to foster the interests of all clusses. It promised to help farmers attain'a "better standard of liviny" by bringing the "long neglected rural areas into the : mainstream of national, development."10 It also promised lite lower clásses that. "money would jingle in your pockets." 11 Wile this offered the poor little more hope than Bustamante's "a little more bread and a lithle more butter" promise decades earlier, the smallest hope of cconomic imisrovement was sufficient to lure the support of the poor majority dway [rom the PNP and towards the JLP by 1980 .

Although ideology played a strong role in the election campuign', public opinion polls indicated that the overwhelming majority" of the Jamaican electorate were disturbed by the country's economic plight. The PNP's economic management was blamed for the crisis, and the majorjty of tile electorate belicved that a JLP government could turn the country around and fulfil its promisc of an carly economic recovery.

-. In ationwidn poll conducted by Carl Stone ${ }^{12}$ one month prior to tive 1980 elections, voters were asked to indicate what they falt were. the 
most important issues in the election. The response indicated tliat

59. 1 percent identified economic issues as the most important, und. thought that it would. be the central quest lon around which irity choide.. would be made. Political and social disordor were rated the second". lughest with 15.7 parcent, superseding ideological lisuos biluch wore considered to be the most important issue by only 10 percenl. Ironlcally, the polls also lndicated that the live leader, Mithul Manley was the leader most liked by 32 percent of respondent's, whilu former JLP leader Hugh Shearer was second with 19 petcent and the lur ront, leader of the JLP, Edward Seaga, 18 percent. However, the mujurity uf respondents felt that seaga was the lebder who visderstuod the ecumuni:

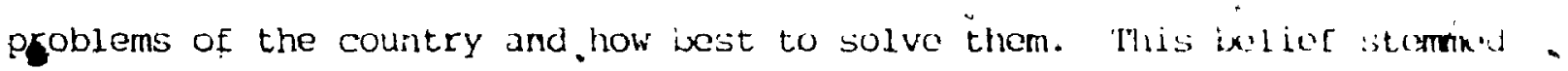
in part from a more positive association of former JLP'administrations

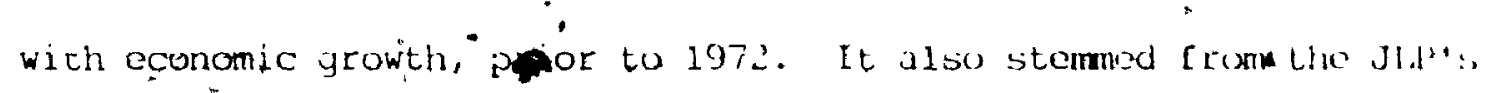
pro-Unitad states.policy, which voters percosived to huve whe builur

- potental for conomic recovery in thic slortest pussible im. Inspile:

- of these two considerations hawever, the overridimy sentiment uf thr. clectorate was that they could not "risk" the ecommic compenuencten of anotiler PNP yovernment.

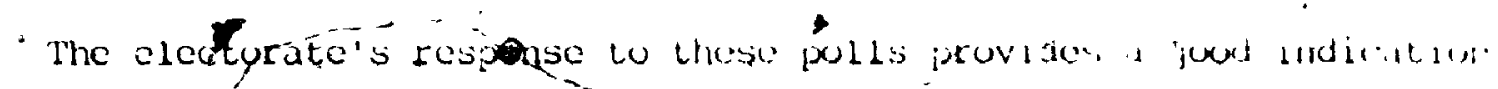

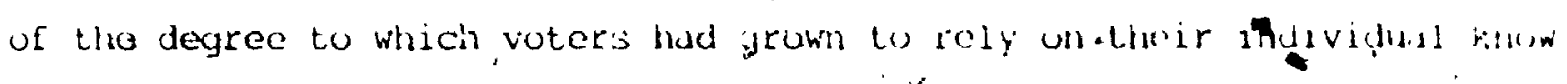

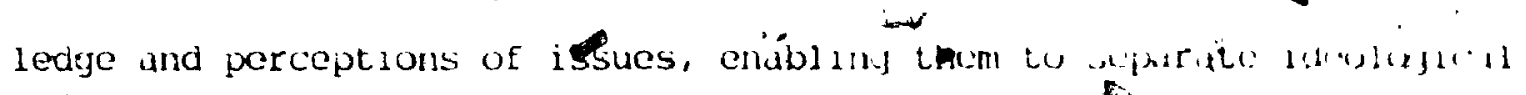
0 from real concerns. As the election fesultis were to andicilw, tir.

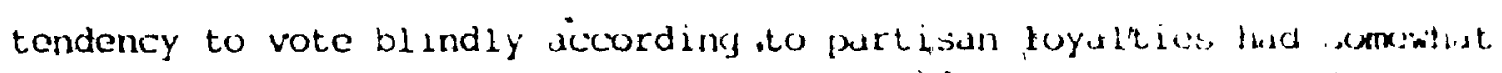

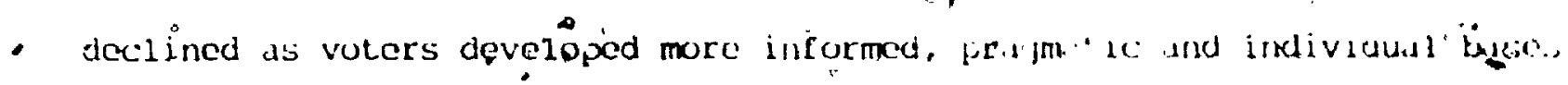

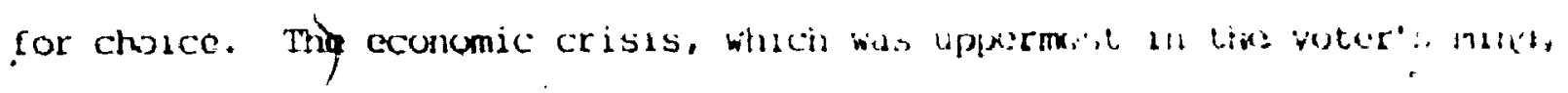

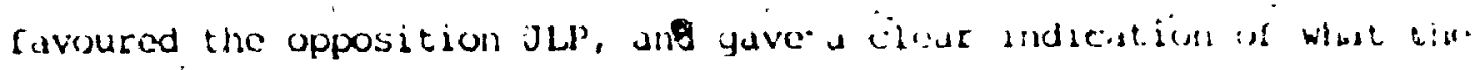




$$
2 \text { aryin } 2
$$


incumbent was likely to face at the polls.

On October 30th, 1980, Jama ican voters turned out in record numbers. Eighty-six percent of the registered voters wont to the polls. The JLP won 58.34 percent of the popular vote, and ydined fifty-one of the sixty seats in parliament. ${ }^{13}$ This was the most lopsided yovernmentto-oppossition ratio in any of Jamaica's parliannentary nlections. It was also the only election in which a political party had won the mujurity of votes in all fourteen parishos. Thus, the economic crisis conifronting 6 Jamaica during tho 1980 elect,wns proved to be both objectively and stratagicaliy bad for the incumbent PNP, but for the ujosition JL"'s campaign it'was strategically very beneficiul.

\section{a}

\section{(ii) The JLP's Iaeological Tendencics}

$\therefore$ The following reactions to the electoral results providef is useful insight into ways in which the ideological tendencies of both . parties have been perceived and interpreted by many Jamuicans: ${ }^{14^{\circ}}$.

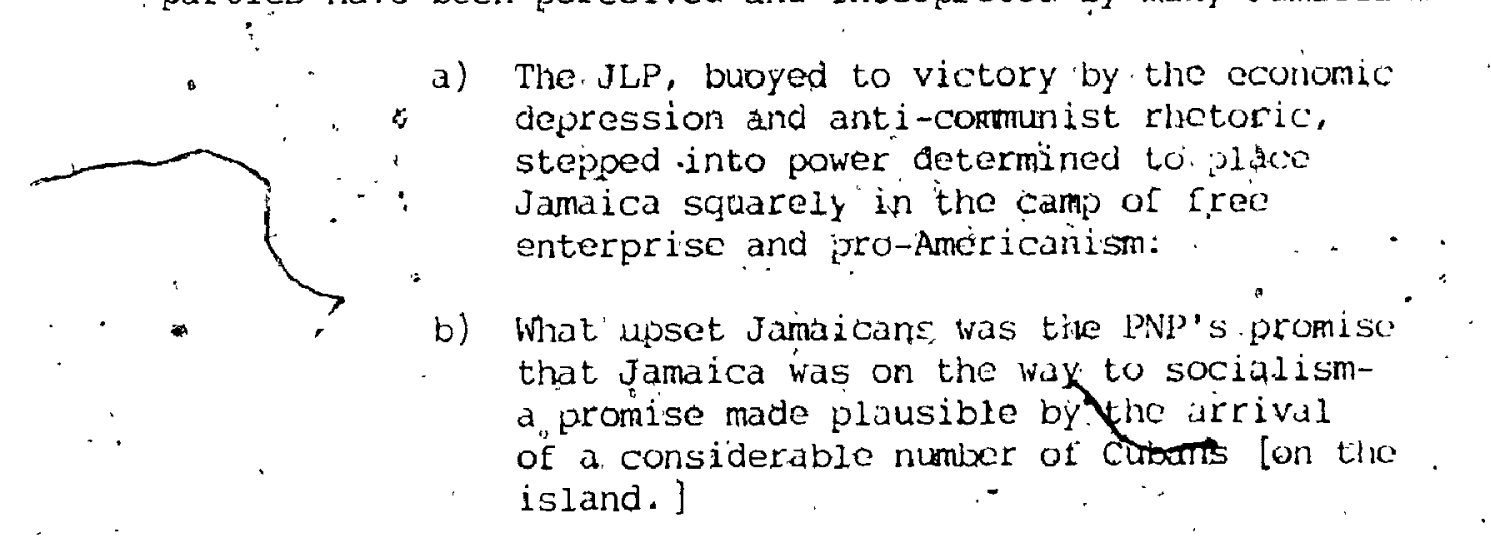

In examining the JLP's ideological tendencies, it is importint to clarify frum the outset that at no time has the party officially attached itself to any ideological label. It is also worth adding that inspite of campaign accusations branding the JLP "CapitaIist" and "praimperialist," and its own counter-accusations of the PNP as. "pro-conmun-", 
- ist," neitiner party has cvor come out in favour of either of these ideologies. In fact, both parties have consistently attacked these ideologies and have sought instead to package their ideological positions in "more moderite terms - "democratic socialism" by the PNP, and "free enterprise" or "pro-Western" by the JLP. It is therefore interesting to note the degree to which the stronger idcological lavels of capitallsm and. communism, attached to the JLP and PNP, respectively, throughout the 1980 eleftion campaign, were perceived by the electorate.

The JLP's anti-commint rhedoric, leveled against the PNP, produced adverse reaction to commanism based on its association with the absense of Ereedom; revolutionary violence, and extreme and arbitrary state power. ${ }^{15}$ The positive reaction to commism, during the PNP's administration, was based on an identification of communismas favouring the masses. More spgcifically, this assumption was linked. to positive images of Cuba. The PNP.'s projection of Cuba as a successful third World. ineighbour state, committed to equal opportunity and the redistribuition of wealth, contributed much to the decline of anti-communist hostility in the society in the midi-1970's.

By 1980, however, the favourable aspects of communism gave way to the more negative aspects, which associated communism with the loss of democratic political freedoms. This perception was aroused by the radical leftists within the PNP, who began to voice a preference for a single-party system, while openly embracing the support of the Communist Workers Party of Jamaica. In spte of Prime Mipister Michael Manley's continued popularity, the public lost confidence in his ability to control the radical pro-cormunist elements in the PNP. In addition, Manley himself was unable to persuade the public of his anti-communist position 



\section{(iii) Policy'Implications}

- One of the first political actions taken by the new JLP administration in October of 1980, was the expulsion of the Cuban. Ambassador, Ulises Estrada, This act eventually led to the complete severing of diplomatic ties ith Cuba in October 1981. Much of the JLP's anti-communist campaign had been centered around the cuban Ambassador's public crit.icism of the JLP, and its pladge to remove him if elected. Once elected, the JLP continued a strong anti-communist. campaign, accusing the Cubans and Russians of communist subversion on the island. This prolonged anti-communist attack; after the complete' . decat of the PNP at the polls and its subsequent disassociation from - the jamaican Communist party, began to be viewed as actions designed by the government to court United States favours. ${ }^{17}$ This impression of the JLP's añti-communist motive appears feasible, in view of the economic policicof the new government and the mes which it sought to implement them.

Coming to office with a strong anti-communist, and pro-American thrust, the JLP immediately sèt about changing the direction of Jamaica's foreign" and domestic policies. This departure from the PNP's antii-, imperialist and democratic socialrist policies, marked a drastic transition rrom the JLP's Eormer "praymatic incrementalist" mode of governing to an "archítectonic" approach which would bring about a radical restructuring of the social and economic policies of the country.

The former government's pro-Tbird. World, non-aligned foreign policy' was abruptiy replaced by the new administration's strong proWestern "open-door" policy. The domestic policy initiatives of the PNP. government, for national ownership of the econbry and self-reliance 


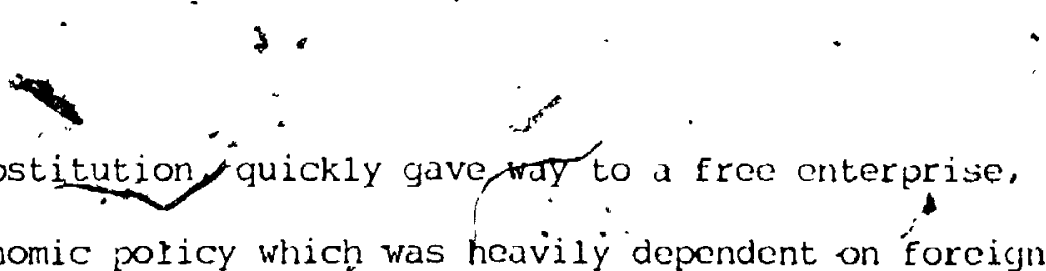

through import-substitution "quickly gave wy to a free cnterprise, export driven economic poricy which was heavily dependent on foreicjn aid and investments. Thus, begận thè' vë́cond overhaul of the Jamaicun economy in eight years, algng completely c'ifferent policy lines. According to Prime Minister Seaga, forcign policy was closely tied to the jovernment's econoroic recovery goals. in uracr "to achieve a rational integration of forcign policy objectives and national interests.". The main thrust of tinis pol ify was to restore and muintain good relations with the United States. Thus, Scagd, who had been elected just five days beforkmthe Reagan administration cunc to offico, was the-first foreign leader to be received in the White llouse in 1981. President Reagan's visit to Jamaica one year later was a yood indicat-. '. ion of Seaga's foreign policy success. Reagan was the first United States President in office to visit the English-speaking Caribbean. since 1934, and despite his speech at a public welcome, in which he called Seaga's election, "A now direction for the Mediterrancan," 19 it was quite clear that, the Caribbean was of high interest to the now. U.S. adminisţration.

- Jamaican-United States foreign policies soon converged on almost every international issue: Regionally, these included Grenada-Cuba relations and support of U.S. -CentraL American policies in Nicuragua and El Salvador. 20 According to Stone, 21 Jamaica became a "surrogate" : of the United States in the Caribbean, "promoting and supporting "Reagan's militant anti-communist foreign policy, in'return for United States economic favours." Indeed, by April 1981, the government had concluded a three-year Extended Fund Facility agreement with the IMF for US $\$ 698$ million, 22 and large amounts of additional assistance were received in 
1981 and subsequent years from other multịlateral sources, private banks and friendily Western governments, led by the United States.

From 1981 to 1983, official United Statés assistance to Jamaica averaged about Us\$200 miliion:annually, consisting each year approx- . imately $\$ 50$ million in balance of payments support; $\$ 90$ million in s:redits for U.S. Foodstufr; $\$ 30^{\circ} \mathrm{mill}$. serve to purchase bauxite roón Jamaica for stockpiling. Between 1981 and 1983, the United states bilateral assistance to Jamaica was the second higlast per capita after Israel. 23

The JLP government also waged an aggressivo campaign to attract forcign investment. "A new agency, the Jamaica Nationa? Investment Promotion Agency, was established to match foreign investors' interests with potential new projects. In the United States, David Rockefeller, the former Chairman of the Chase Manhattan Bank, presided over a task force of prominent U.S. businessmen to attract new investments to Jamaica. Similar groups, wẹrc organized in Britain and Canada.

: A major outcome of the JLP administration's close ties with the United States; was the momentum generated in support of the Caribbean Basin Initiative, which became operational following Congressional approval in January 1984. This law allows Jamaica and most other countries in the region to benefit from a tivelve-year free trade access to the united States market for most of their products. It also provided for economic support funds and tax credits to U.S. corporations to encourage invest-. ment in the region. 24

. In the area of dómeștic policy, the Seasja government drastically revised a number of imporțant policies.established under the PNP government. In place of the previous emphasis on national ownership with a strong 
emphasis on state ownership, the JLP sought to promote foreign, investment as the major iffpetus to economic growth. The government also comitted itself to a policy of rapid divestment af state-owned enterprises,. especially those that had bechme a burden. on the national budget. A Divestment Commission wa's set up to sell various public cntcrprises which included a dry dock company, a dairy processitity plant, a paper factory, two agricultural enterprises, an airline catcring service and the island's second dally newspaper, the Daily News. The National lotels and Properties Company, which managed a large number or hotels takel uver by the previous government, was also instructed to offer the hotels ror lease or possible saie. 25

Exports became a "major priority, replacing the PNP's. cmpilasits on self-reliance and import substitution. The government if ifed neurly all of the restrictions placed on the granting of import licencos by the former government, in order to facilitate the acquisition of ruw, materiats, supplies and equipment. needed for the'export trade. In addition, the State Trading Corporation was scrapped and replaced by a now böly, the Commodity Trading Company.

The government"s ability to secure forcign capital gave a corlain stimulus to domestic economic activity. Reports from the Central Bank of Jamaica and the IMF in mid-1981, indicated a significant growth in the construction industry, non-government services, the distributive trades, månufacturing, agriculture and 'fisheries. Total export's increased by $\therefore \quad 1$ percent in $19 \dot{9} 81$ - the first increase since 1973.26.

puring 1981 the local investment climate greatly, improved, and - 244 investment proposals were made by local and foreign interests. Sixty of these, representing a total investment of $J \$ 676 \mathrm{million}$, came from 
foreign investors, and the remainder from locial investors totalled J\$433 million. 27 .

\section{- (iv) Implications for Development}

During the first year of the JLP government, à mood of optimism.

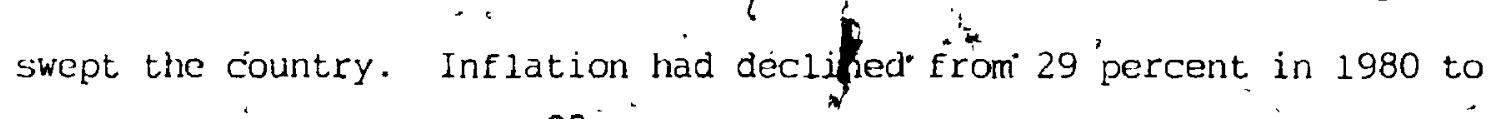
6 percent one year later. 28 Businessmen expected a quick return to cconomic prospererity, and the increased flows of capital; credit, loans and "imported goods, fed this opitmism. The unemployed, waited for jobs to be created. Workers looked forward to greater purchasing power, and demanded more pay from employers and the business sectors. Every sector of business. (large, medium, and small-scale), geared itself for a boom in the Jamaican marketplace. 29 Thus wide-ranging expectations were heightened for the immediate fulfilment of the government's election promise of an early cconomic recovery.

Indeed, throughout first year of the JLP administration, the economic and social picture seemed bright. Imported food items returned to the store. sheives in large quantities, eliminating the acute, shortages of the later PNP years. The crime rate fell dramaticalyt families who had migrated began to return; the emigration of middle class professionals and upper and middle class businessmen virtualiy stopped, and tourists began to return, in large numbers. 30 . It appeared as if policies for an early economic recovery were working, and all expectations would be furfilled.

By-the end of 1981, however, the JLP's political fortunes began to deciine as negative economic trends began to set in. The large inflows of consumer imports created an oversupply, while purchasing power had 
)

increased only slightly. As a result, the rato of sales fur many products became sluggish. 'In addition, the renewed recession in North America and Europe, substantially reduced the anticipated inflow of investments, and only a few thousand jobs were croated from the now investment projects which actually' started. These could not compensate for the fact that more jobs were being lost than now jobs being created. 31 High unemployment ievels, estimated in the region of 30 to 35 percent in most areas, ${ }^{32}$ remained virtually unchanyed.

Efforts to reduce the increasingly huge budget deficit led to increased taxation and a more efficient tax collection system, and even tighter controls on government spending, particularly in the ared of social programs. For example, the public sector relief employment was dropped.

Domestic agriculture was also affected by ovgrsupply, due to excessive production and lower export earnings. Rural consumers were unable to purchase products because of a shortage of cash. 33 .

"Local manufacturers, accustomed to a protected domostic market.. Y. Local manueture were shaken by the prospect of competition from imported goods. Accordiny to Stone, ${ }^{34}$ the shift in emphasis from domestic manufacturing to export production was beyond the depth of most private sector manufacturers, who "built up opposition to the open-economy policy and caused a rapid decline in private sector support of the government." The middle.and upper ciass consumption of imported luxury items grew tremendously. 'As a result, merchants were outbiading manufacturers for the scarce supply of U.S. dollars. With falling sales, expensive and inadequate foreign exchange and intense competition from imports, "manufacturers felt that their surviyai was being threatened by JLP policies, and became increasingly 
critical of the government." 35

While the middle and upper classes displayed new patterns of conspicupus consumption (for example, luxury cars, video sets, color televisions, etc.), the problems of the majority lower classes increased. Many were beset by zayoffs in the manufacturing industries; inadequate employment creation for young school leavers, and lack of money. This resulted in the declining sales of small vendors and poor farmers.

The interests of every strata of the society were in some significant way adversely affected by the JLP's domestic policies. Policies which had contained inflation in the housing market and controlled rents under the PNP government, wore abandoned under the JLP. The result was a dramatic increase of between 50 and 100 percent in the middle and lower middle class rentals, and complaints of landlord exploitation became widespread. ${ }^{36}$ By early 1982/, optimism about the JLP's success $\because$ in leading the country to economic recovery began to dissipate, but there was still a cautious hope that things might bet better.

By mid-1982, however, the effects of the recession in North America and Europe began to be more harshly felt in the Jamaicain economy, as dwindling inflows of capital were insufficient to fulfil the promise of economic recovery. The value of total exports fell by 10 percent in 1982,' and remained the same in 1983. The bauxite/alumina industry, which contributes 70 percent to the total value of exports, suffered a fall in $\because$ production Erom 12 million tonnes in 1980 to 8.6 million tonnes in 1982 , producing a loss in revenue of US $\$ 90$ million. By 1983, production had gnce again fallen to $7.3 \mathrm{mili}$ ion tonnes in spite of a US\$32 million sale

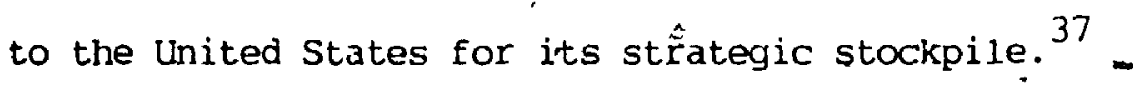

, Production in the sugar and banana industry continued to be low. 
In 1981 alone, the sugar industry had lost US\$112 million. 38

Manufacturing had also farlad to jrow due to the shortage of forcign exchange to buy raw materials, and the inerficient, system or competitive" bidaing for import 1icences. 39 In addition, foroign exchunge curningsi were drained away by the high cost of imported oil, which took more than 65 percent of foreign carnings. In 1980 ulone, Jamuica paici US\$118 million for oil imports, leaving only US $\$ 274.6$ million from its tutul. overseas carningis." 40.

By mid-1983 it became evident that the economic momentum which began in 1981, could nöt be kept up. In one year.bau. i te exports haci decreased by 30 percent; net foreign exchange reserves had decinined by over 20 percent and the sross external debt had increased by more thun 30 percent. The GDP, which had grown by 12, percent in the 1981-82 perivd, had slowed to 2 percent in the $1982-83^{\circ}$ period: 41

The social effects could be seen in increasing crime ds a lurye number of youths entered the ranks of the uncmployed. In spite of the - governments's campaign to impress upon the Jamaican workers. the necd to make sacrifices in the national interest; islandwide workers strikcs swopt the country. Strikes began by bauxite workers in 1982, isrcicipitited further strikes by dockworkers, railway workers, water industry workeris and clectricity and public transport workers. 42 Incvitably the jovrernment wais blamed for all of the country's problems. $y$

By early 1983 the majority of people had become impaticnt with the - JLP government, and were beginning to lose hope that any real improvements in the quality of 'life would be achieved under a JLP administration. The fact that the inflation rate, which had fallen to 4.7 percent in 1981, had. grown to 18.5 percent by 1983, dici, not encourage further hopes. 43 in 


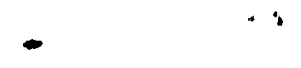

a sudden attempt to rescue its political future, the JLP exercisèd its constitutional prerogative under the Westminister syster, and called a national elcction after only three years. in offige.

\section{(v) The 1983 Elections}

The two major issues' which dominated public debate between 1982

ard 1983 were the state of the economy and party ideologies. 44 By mid1982. the faltering economy had rapidly eroded JLP support, and as faith in its promised economic recovery declined, memories of the Manley period became more positive. In particular, there was a growing tendenry to oassociate the PNP's policies with the more positive aspects of government; such as' farouring the interests of the poor and promoting high levels of public spending.: In addition, the anti-communist issue had long lost its appeal, as economic issues 'Grow more and more dominant in the publ ic mind. By October 1982, Stone's pol1s 45 indicated that the JLP's popular support was significantly" reduced to 38 percent, a margin of 5 percent below the" PNP. This trend continlied except for one period between october and. early November 1983.

During this period, the events surrounding the invasion, of Grenada temporarily restored the salience of the anti-comunist issue by re-opening fears about PNP-Cuba ties. Developments in Grenada brought back into.

focus doubts about Michael. Manley, which nad been formed in the late 1970's when many voters felt he had lost control of the party to radical proMarxists. In view of the Grenadian situation, many felt that had the PNP $\therefore$ : won the 1980 election; what happened in Grenada might have taken place. in Jamaica. Stone's research ${ }^{46}$ revealed that the popularly held view was that Manley might have been similariy encircled by the leftist radical 
elements (with foreign communist support) and could have lecome a "casualty" of a far-left communist porer-play in much the sume mumer ihut. the Grenadian leader, Maurice Bislop had fallen victim. Isishop had been isolated within his party, the New Jowel Movement, by a fuctiwn lud by Deputy Party. Leader Bernard Coard, which attäcked Bishop for boim, too middle class and not sufficientiy Lorinist.

In an effort to reflect a-more moderate ima, je, by $198 \mathrm{k}$ the IND had succejeded in eliminating the mare radical membors of the pargy. In . addition, the party.'s General Secretary, D.K. Duncun, who had led the wor. radical faction, had resigned in March 1983.47 Inspite of tile jrujeclion of a more moderate PNP imace, however, Michael Mankoy contigued to suplourt Cuba throughout the Grengdian crisis, while Jitrongly criticizing the Jamaican government's role in the joint military action as pro-imperiali:, and interventionist. The conscquence was a substantiul 5 percent increase in JLP popular support gbove the PNP during this period. 18 With the idrst. Eavourable change in públic support since mid-1982, "Lhe JLi" werjan to reassess its political options.

; The econoric problems facing the country were soon to be compunded by the yovernment's failure of the IME test in Septeriber of 1983. BY ". November, a new IMF agreoment was announced ${ }^{49}$ which would take effect in April 1984. The new agreemen inolved a massive 43 percont devaluation - of the Jamaican dollar, and a significant increase in the cost of iiving over and above the 18.5 percent increase in 1983 alone. In vicw of the impending economic consequences, and the party's current popularity over the Grenadian issue, Scaga opted to call a "snap" election. 50

Ironically, it was the PNP which provided the government with the golden opportunity to call an early election. After the new devaluation 
Was announced in Novemiver, the PNP called for seaga's resignation from his poitfolio as Finance Minister. Seaga then siezed the opportunity to : interpret this as a question of comfidence, and immediately called the clection to settle the issue. 51 .

The JLP's reasoning was fairly cleur. If returned to office, the government would be yiven mure time ror its conomic policies to bear

- Eruit. This hope largely rested on prospects for an early upturn in the United States economy. Hence, the election was announced on Friday. 25 November; nomination day for Tuesscay, 29 November, and election day for 15 ecember, 1983.52

The. wP did not expect' an-election, and was not prepared for one. Both partics had agreed not to hold an "election until a new voters' 1 ist was prepared. It was expectẹd to be regady by Spring, 1984 and would have. added more than 100,000 new voters who had reached eightcen years of age betwcen 1980 and 1983. These ware likely to favour the PNP. ${ }^{53}$ "'.

The PNP, still divided at the time, was nat sufficiently prepared to fight an election. Like the JLP, it also veighed its options, and Geided to boycott the 1983 elections. In the PNP's reasoning, a boycott over the voter registration issue was likely to create a political controversy, which, along with the further anticipated economic hardships, might once again swing public opinion against the government, thus forcing it to call elections at so later date.

The PNP!s thinking was only partially correct. Popular opinion : did swing in its favour. Howcver, the JLP carried out the elections as planned and stubbornly refused to call another until the new term expired. According to polls taken just prior to the elections, ${ }^{54} 59$ percent of the public disagreed with the JLP's decision to call snap elections on 
the ols voters'list, and 70 percent ruwourad the [NP"s vien that a new elequion should be called in 1984, when the new vuters list-lies terdy.

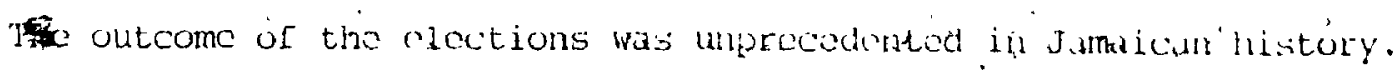
Noither pirty haci ever refused to contest yengr.ul alcotioni, and mo

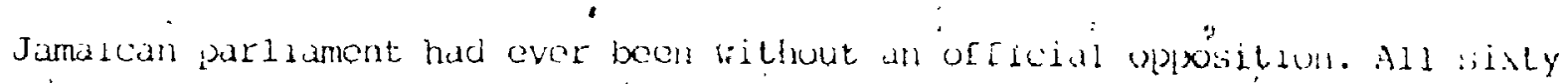
seats, of the ner parliament" - fifty-four of wich wate uncuntested - hent

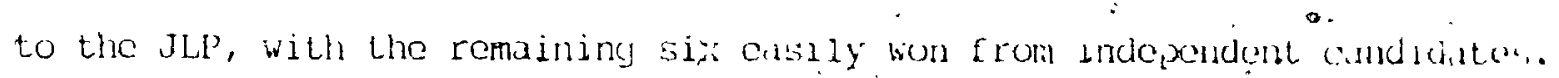
Not surpeisingly, the turnout at the polls was extrenely low.

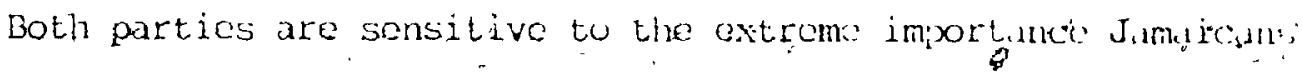
place ol the maintonance of a strong two-party demucratic syatem, therroure both took inmeciate mousures to assure the puble of their owm faith in lhe: system. The day after nomination dey, the ENP amouked a "Pou!so's. Forum," hinch would serve as a forum for the copression of uppouition

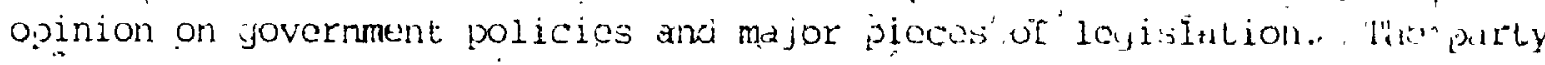

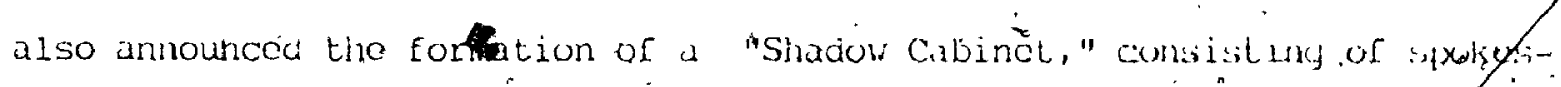

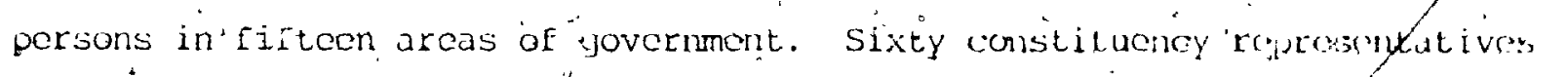
were also nimed siortly after tho erectionis. "is

- The JLP also planned a number of streps lo nelp compengulu for the lack of parliamentary opposition, and announced at a mass pereting that "people-based" organizations would be estublished to provide popular. ropresentation. Public Utilitíos Minister, Pearnol Charles, "must imve: intended much the same thing when he announcéc at a public yathoring that "under the now government, the people will be the opposition."

- Ironically, tho Jamaican public learned only after the cicicion of the one-party government, tilat the new voters' list would huve been

- extremely favourablo to the PNP. Stone's survey" conducted afiter nomination day, indicated that with the inclusion of the new poters, unly 
45 percent of the popolar vote would havaogone to the JLP', while 55 percent would have voted PNP. This led to his conclusion that,

As a result, of the election boycott, the country

is Eaced with a potential situation where the

majority party is not represented in parliament,

and the minority party reprosents the entire

country.

With a renewed term of office, the JLP government continued its

policy youls for economic recovery, but its prospeats for achieving

succesis within the mandated five year term of office appeared bleak in

1981. The massive inflows of forefgn capital into the economy had done

littie to improve the standurd of living for the majority of Jamaicans.

Unemployment maintianad the same high levels fof the previous three years, anch between 1982-1984, real per capita income remained essentially the" same at approximateíly uS $\$ 1,200.58$. Inflation, which had been reduced to 1.7 , percent in 1981 , Elimted to ?0 percent in the first six months of 1984 , and by 1985 the Jamaican dollar had devulued to US\$0.25 from US\$0.50 in 1980.59 The GDP, had appreciated by 2 percent in the 1982 -1983 period, but by that time' the per capita foreign debt had alrcady" exicecded UŚ\$1,000.60

- Supportars of the PNP's policies have suggested that the JLP's policies fidied because of the neo-celonial and capitalist policy direction. ${ }^{\text {al }}$ others have criticized the PNP for its, democratic socialist , policies, which they, feel had retarded the capacity of the Jamaican economy for sustaincd recovery in the 1970's. 62 The evidence, however? leads to the conclusion that noither of the two governments have exced led. * in the implementation of their policies and the achievement of their goans. 
(vi) General Observations

After cight years of the pNp's domocratic socialism and thee years of the JLP's "Iroo ontorprise". capitalism, the Jamuican counumy Eailea to respond to aitich ideological !rescriptions:

The pwe's ideological direction lod to a fureign policy whish reflected a genuine. search for, a way to brokk with Unilod St.1le: neocolonialisfm. The result was an extremily dumajing rosponste by ilue. United States, which viewed that poḷicy as anti-Aricrican and humilo lu Upited States economic and politiçal juterests.

The PNP's clomestic policy was also consistent wa th ids; idculen;ical dirsction. It sought to develop a more just sodicty in whicil cepuld opportunity, for all could be roalized through, popular polilicil parlicipation and a redistribution of woalth. The resilt wis a hiofly polurizod socicty in which the wealthier classes fought to protect their intercists, while the poor looked to the goverment to funfil ili, jromiso or weulth redistribution. The PNP yoverrmeilt did make several bold attempt:i tu

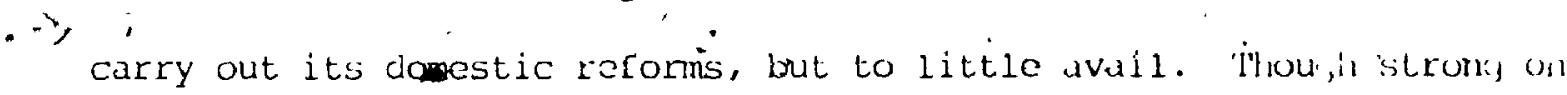
idcological pronouncements, the government proved weak in tike aria of policy implicmentation.

- The redistributive projects paid out millions of dollars '́rur essentialiy non-prociuctive work. In addition; lhere were rew comislete.. plans or strategies guiding the govormment's joillcy iniliatives for productive enterprises, other than the take-uver of bankrupt private enterprises to maintain employment. These in turn réquired lurgetsubsidies and supplies of foreign exchange to stay afloat. In consoguence, no resources were left to plan or develop new public enterprišcs, which might have promoted the doal national self-reliance through the 
production of basic needs. of the efforts made, for example, in housing, state rarms, and community services, most failed because of poor management and labour indiscipline, resulting in cost inefficiency and wate or pubilc resources.

Fịnally, the available financè, tecinical assistance jand manägement capability were not sufficient, to render the PNP social reform policies a viably cngine of growth and economic recovery. 63 The JLP's ideology was based on a capivalist mode of development, which was reflected in its foreign and domestic policies. Un'like the PNP's non-aligned foreign policy, the JLP's pro-Amertcan policy was .hartily received by the United States and its Western allies. This was attested to by the large inflows of aid and investment capitai wirich Jamaica rcceived inmediately after the JLP government took office in 1980 . Failure of the JLP's foreign policy must, however, be frked in large measure to its heavy dopendence on exterral aid and trade, both of which are sensitivt to the inherent uncertainty of external forces; which are beyond the government!s.control. Invariably, a small economy such as, : Jamaica's, which relies heavily on the ebb and flow of the international monetary system, is certain to bear the greater burden of warld inflation and economic recession. This was evident in mid-1982, when the global' /recession reduced anticipated foreign investments to a trickle, while. increasing the neceissity to borrow more money from institutions such as the World Bank and the IMF, resulting in increased domestic hardships and even greater foreigh capital debt dependency. !

The main thrust of the JLP.'s domestic policy was to encourage private sector initiatives in order to devclop a competitive, export oriented economy. This policy failed to achieve the anticipated 

the PNP's democratic socialist policies are likely to create any real progress towards economic recovery, units they can Fastaion the Jamaican private sector into a force strong cnough to meet the challenge. This would require not only massive incentives, but also a high level of confidence in the policy-making and policy implementation cápabilities a the political leaders.

On a broader level, political lcaders need "to promote a sense of national unity. If the couritry is to progress towards positive development, lcaders must estabilish a broadly based consensus on cconomic and social policy. Only this will provide the kind of stability and policy continuity essential to the unavoidably slow and difficuit path to national evenent. Swceping ideological solutions from either of the two parties are unlikely to have" any relevance in circumstances that

- resuire economic râther than politicad solutions. Unfortunately, the diverse idcological and consequent policy differencess "between the two contending parties "fecer little höpe of consensus and hational unity at". the present time.

From all indications, the present government is likely to be put out of office if substantial economic and șocial benefits are not forthcoming before the next election: The effects of the prolonged period of high unemployment; the steady decline in living standards since early 1970, and the failure of the political deadership to deal with basic economic and social problems, have caused a growing lack of faith in the leadership of both partles. As the JLP-PNP two-party tradition is so. entrenched in Jamaica, it is 'unrealistic, to hope that in the foreseeable future, a third party will emerge with the kind" of leadership needed. It is equally unlikely that either Michael Manley or Edward Seaga will 
resign from their party leadership bofore the neft ciections. Hence, the electorate is faced with the grim prospect of haviny to chogso between two extreme policy directions, both of which have providud little in the way of national development, and pore specifically, material and social improvement for the majority."

It is also unlikely that either party will charige its juldey" direction. Just as Seagja has repeated the scenario of the late loues by holding to the original JLP policiẹs or the 1950's aria r960's, ir the PNP is returned to arfice, it is possibia that "its policios and the consequences will be equaliy predictuble. Whether or not " moderate PNP image will survive the initial "vote "winfing" stuge, and

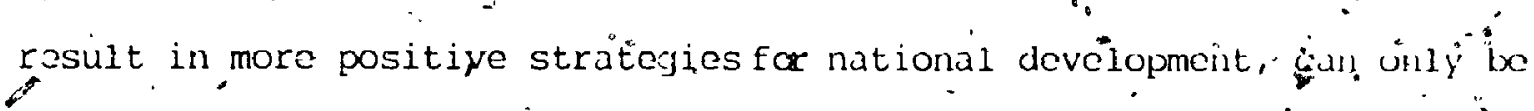
determined if or when the party is re-clocted.

- One positive aspect arising of the pust decade and a half of political extremism, tias been a more informed alecturate who are less. likely to vote according to party loyaltics and more according to basic a issues. The past, fifteen years'has"meen an education for the Jumuican electorats, politically. They have heard the ideological rictoric and have experienced the policy eresults. Both parties are now. fully aware tiat they. can no longer rely on a solid bloc of traditiondil party

- loyalists to get them clectod. In ruture, parties must perform woll in government if they are to romain in polter. 
1 see Carl Stona's The Political Opinions of the Jamarican People: 1976-81, Kingston, Jamaica: Blackett Publishers, 1982, p. 12. Carl Stone is a Professor of Political Sociology at the University of the West Indies, and a highly respected author and journalist: He is also Jamaica's.leading public opinion.analyst. Stone introduced the system - of public opinion polling to Jamaica in 1974, and was extremely accurata in his prediction of the actual vote results in the 1976 and 1980 elections. His polls are well referenced throughout this thesis as. . they provide valuable information on the mood of the country and the public reactions to poth parties" ideologies and policies. The polls also help to explain the level of rationale which governs voting behavior. His research methodology is described in detail in the. introduction to his book, Democracy. and Clientelism in Jamaica, $\mathrm{Nev}$ Jerscy: Transaction Books, 1980.

2 John D. Forbes, Jamaica: Managing Political and Economic Change, Washington: American Enterprise Institute for Public Policy Research, 1985, pp. 30-35.

3 Anita M. Waters, Race, Class and Poiltical Symbols, New Brunswick: USA: Transaction Books, 1985, p. 199. Over 750 perşons were reported akilled, including one electoral candidate between the February announcement of the election and the october election itseif.

\section{?}

4 see añdrew Kopkind's "Trouble in Paradise," Columbia Journalism Review, March 1980, pp. 41-50. This is an excelleat article on the ${ }^{\circ}$ propaganda machinery at work during the 1980 elections.

5 The statements rered to in this passage were taken from numerous reports in Jamaican newspapers of speeches and party propaganda literature, between the election period of 1979-1980. The paper most referenced was the Daily Gleaner and the Weekly Gleaner, then the Daily News. The Daily and Weekly Gleaners has a JLP bias, but provided more , extensive coverage of both party campaigns, while the Daily News, (now defunct), projected a uniformly PNP roias and was not as widely circulated.

6 Prime Minister Michael Manely had gained a considerable reputation abrozd for leadership in international organizations such as the NIEO, and the Non-aligned Movement and the International Bauxite Association. However, these successful foreign ventures had lost their meaning in the face of tire domestic economic crisis.'

7 Edward" Seaga, The Daily Gleaner, 10/19/80. ?. 11.

8 waters, 1985, p. 246.

9 Ibid. p. 223.

10 The Daily Gleaner, 10/16/1980, p.9. 
Chapter IV

11. The Daily News, 10/15/1980, p. 8.

12 Carl Stone, "Public Opinion and the 1980 Elections in Jamaica," Caribbean Quarterly, Vol. 27, No. 1, March 1981, pp. 9-12."

13 the 1980 election is considered to be one of the fuirest ever " held in Jamaica. This was due to important electoral reforms adopted. by Parliament in 1980, out of wich emerged a bi-partisan. Electoral Commission. For further details see article by the Commission's Chairman, G.E. Mills, "Electoral Reform in Jamaica," Caribbean Quarterly; Vol. 27, No. 1, March 1981, sp. 20-31.

.

14 (a) Waters, 1985, p. 27, and (b) Peter L. Berger, "Can the Carribbean Learn from East Asia," Caribbean Review, Vol. X.II, No. ?, -Spring 1984, . p. 7.

i 15 Cari'stone, Democracy and Clientelism in Jamaica, Now Jerscy:Transaction Books, 1980, pp. 198-201:

16 Ibid. p. 187.

17 Trevor Munroe, "Jamaica' in Turmoil," Marxism Today, Vo1. 25, No. 5. 1981, pp: $23-26$.

18 Edward-Seaga, "Report to the Parliament on the Administration's Third Year in of fice." Jamaica Information Service, Nuvomber 29, 1983 , p. 3.

19 cited in watèrs, $1985, \mathrm{p} .249$.

-20 Edward Seaga,. "The Jamaica Labour party Focoign Policy Guidolincs," Kingston: Jamaica Information Service, December 1980, p.7.

- 21 Earl Stone, "Jamaica in Crisis: From.Socialist to Capitälist Management," International Journal, Vol. 40, Spring 19985, p. 7.

22 A.J. Payne, "Seaga: Jamaica After One Year," World Today, Vol: 37 , No. $11,1981, . \mathrm{pp} .434-440$.

23 Forbes, 1985 , pp. $35-40$.

24 Peter L. "Berger, "Can "the Caribbean, Learn Erom East Asia," Caribbean Review, Vol. XII', No. 2, Spring 1984, p. 7, and Wutcrs, - 1985, p. 252 .

- 25 Fitzroy Ámbursley, "Jamáca: From Michael Manlex to Edward Seaga,". in Crisis in the Caribbean, ed. Fitzroy Ambursley and Robin Cohen, Londorn: Heinemann, 1983, p. 96. Cited from West Indian World, August 7, 1981.

26 The Financial Times, 1/12/81. 


\section{H.}

\section{Chapter IV}

27 Ambursley, 1983, p. 97. .

28 Berger, 1984, p. '8.

29 Carl Stone, "Seaga "is in Trouble: polling the Jamaica Polity. in Mid-term," Caribbean Revicw, Vol. XI, No. 4, Fall 1982, pp.5-29.

30 Berger, 1984, pp. 7-8.

31 The New York. Times, 4/28/82

32 Stone, 1982, p, 6 .

33 Ibid. pp. $+5-7$.

34 Ibï. p. 6.

35 I'oid. pp. 6-7.

36 Ibid. pp. 6-8.

37 The Financial Times, $12 / 9 / 82,1 / 20 / 82$, and The Weekly Gleaner, $12 / 2 / 81,12 / 9 / 81$.

38 The Financial Times, 1/14/82:

39 Forbes, 1985, p. 37.

40 Ambursiey, 1983, p. 98.

41 Berger, 1984, p.8.

42 Ambursley, 1983, p. 102.

43 Forbes, 1985, p. 39.

4A Car1 Stone, "The Jamaica Reaction: Grenada.and the Political Stalemate," Caribbean Review, Vol. XI1, No. 4, Fall 1983 , pp. 31-32, $60-63$.

$\rightarrow 45$ ibid. p.32.

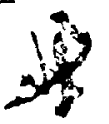

46 Ibid. p. 60.

47 Whaters, 1985, p. 259.

48 Stone, 1983, p. 61. '

- 49 Berger, 1984, p.8.

(50 Forbes, 1985; p. 43. 


\section{Chapter IV}

51 Berjer, 1984, p. 8.

* 52 Waters, 1985, p. 273, and Forbes, 1985, p. 4.

- 53 Forbes, 1985, p..44.

34 Stone, 1983, pp. $61+62$.

55 The Daily Gleaner.. 12/2/83, p. 1 .

56: Ibia: $11 / 30 / 83$, p.1.

57 Stone, 1983, p. 62.

58. Forbes, 1985, p. 39 .

59 Watèrs, 1985, p. 259.'

60 Forbes, 1985, pp. 39-40.

61 Gearge Beckiford and Michael Witter, Small Garden Bitter Wecd: The PoIitical Economy of Struggle and Change inviJaica, Kinjston, Jamaica: University School of Printing, 1980.

62. see Jennifer Sharpley's "Economic Manayement and the IMF in Jamaica: 1972-1980," Derap Working Papers, Bérgen, , 1981.

63. Stone, 1985, p. p.. 282-311.

64 The World Development Report tables, Wurla Bank, 197$\}.$

65 Stone, i985; 2. 308.

66 Fvid. p. 309.'

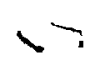




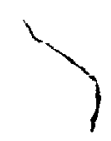

CHAPTER V

\section{SUMMARY AND CONCLUSION}

The sindings of this study contradict the popular notion that a. politics is a pre-condition for national development" in the Third world. Using Jamaica as one example of a developing country which is generally recognized as possessing a well funttioning system of democratic pelitics, it was possible to demonstrate that the establishment of such a system is not, in itsélf, a sure path for national development. It further showed that the system could, to a large extent, contribute to the growth of negative development patterns. The analysis in "Chapter one, of certain characteristics of political parties in a democratic political system provided some extremery useful insights into the nature of this contradiction. They therefore provide a good basis for a final assessment of the Jamaican political parties with implications for national development.

It is evident from the characteristics of the Jamaican political System, trat a great deal depends on the two main principles which govern competitive electoral politics - that parties will al Eernate in government, and that governing is only for a limited period of time. In a developing society such as Jamaica, the demand for essential material needs greatly exceeds the resource cápabilities of the country. Ideologies and policies which inform a party's approach to governing therefore have considerable ' influence on the results achieved during the limited term of a governiment,

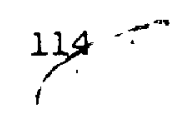


as well as on the party's future in government.

The two approdches to governing - "architectonic" and "prajmatic," have been adopted by both Jamaican political parties at one time or another. Between 1950 and 1972, the policies of both partics convergèd on the pragmatic approach to national development. Remaininy withn the status quo, they sought to apply policies on a "gradual, incrementul basis, on non-contentıus yrounds." This aproach proved most vuluable, ." politically, in that it provided a unifying force at a critical staye of post-independence political development, by allowing the country to gradually institutionalize a stable political system. In an ecomunic: sense, however, the results were both positive and negative. Illus, th' economy grew and diversified and social programs were gradually intruduced. However, the kinds of economif policies which the government:;。 adopted produced an imbalance between massive cconomic yrowtin and economic and social development.

Economic yrowth produced high expectations from all clusses for more immediate social and material reward than a yradual incrementalist. "approach could, accomodate. The result was an extreme imbalance in the distribution of wealth between the vast majority of pour and the small affluent minority. "The difficulties inherent in the "pragmatic" incrementalist approach to government in a developing country such us Jamaica, became evident in the widespread social and political unrest which pervaded the society by the late 1960's. "This, in turn resulted in the adoption of a. new "architectonic", approach ta governing by the People's National Party, which sought to build a new social reality based on stirong ideological notions of social equality. "The Jamaica Labour Party's reactionary response to this approach precipitated 
its own transition from a praymatic to a more radically ideoloyical aprodeh to its former policies. Since 1972, this change produced two'. dramatically opposing party policies on "highiy contentious grounds." Ihe alternations of governments since that time has resulted in the dismanting and restructuring of social and economic policies when each , iarty took office. Consecuantly, serious disruption in the planniny and implementation of long-term policies, necessary to the achidevement of lusting development goals have resalted.

The "ldeological tendencies of both parties have also created a neyative balance between "normative desires" and "objective reality." Both promised to create better conditions for the Jamaican people in - the shortest possible time. Michael Manley's RNP heightened popular expectations for greater social justice and equality and sought to brinj these about through greater popular political participation, wider public control of the nationgl resources, and a redistribution of wealtin: Edward Scaga's JLP pledged economic recovery in three years, with increas-

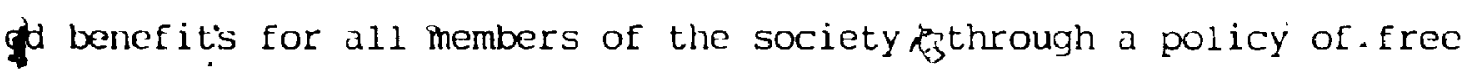
. enterprise economics which was heavily dependent on external resources. Both policies, designed to fit the desires of the voting majority, were burdened with a preponderance of ideological goals which obscured the objective realities of limited materiat and human resources, and unreliable internal and external factors. These crucial factors ultimately determined the outcome of policy initiatives. . Neither party made any. serious attempts to "create a pétter appreciation in the minds of the elfuinrats of what was realistically possible." In order to be elected, parties generally appeall to the popular desires of voters, rather than articulate the real difficulties 

"wealth redistribution and social readjustment. Likewise, the JLP was ; unable to sustain̈ its busifiess-oriented domestic policy joals, because of its fallure to successfully implement the structural changes in the society necessary for their achievement. In addition, the party managed to distance the pooror majority by concerfrating on economic policies?. which demanded unbearable ohort-term suckificen. Hence, both partius mardyed to "distance, the publie interest. joais" by inadequately identiryiny aridor splving problems affecting all levels of the socicty. Yet, while the policies of the two parties tended to create class polarization in the socicty, all classes aventlally found comnon cause in their mutual dissatisfaetion with both party governments.

The points made rogarding paricy determifiation and electoral expediency have been demonftrated in this study. While it was desireable for partics to encouragetr "flexible and subtle relationship between clectoral popularity, and "polrcy," balancing these proved extremely difficult "in circumstancess where success at the polls depends on the party's response to popular policies which demanded almost immediate results. A major pre-condition for the attainment. of balanced poilicies is the development of a broadly-based consensus on national yoals, which in turn rociuires long-term adjustments, personal sacrifices and far- o sightednessi on the part of the clectorate (and of course the prolitical. leaders.) Hoifever, the croation of a national consensus on long-tern development goals, is virtually unattainable in a society with a highly poiarized two-party system such as exists. in Jamaica today. In these circumstances, the electorate is caught up in a cyçle of extreme policy divisiveness, where ridding the country of a government that is performing poorly - rather than electing a party which offers more rational choices - 


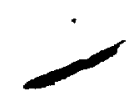

becomes the primary objective of votiny.

While it is trate that strong competition between the two partics and their alternation in power constitute vise or Jamulca"s principal political strèngths, these factorśs are also a majur source of woukness. The primary rationale for the existence of a strong political system should be to promote national unity, confidence, consensis on ridionul goals and other essential buldang biocks for halional development. Where these are sacrificed to extrome political polarizatiun, frequenl idoulogical and policy swings, class divisions and excessivive distrust amom leaders, the strength of the system bocomes a major stumbling block to development.

Although the ideolosies and policies of both pallies luve returded the development process in a number of aspects, it would dx: unfair to suggest that the political partics were primarily motivated by a zealous quest for self-indulgent power. Both took ldeolafical and pulicy approaches which they assumed to be in the best jnterest of the nution. Weaknesses arose from the Lnability to implement policies in a reasonuble and rational manner. Therefore, while it, is possiple to blame structural domestic problams and external forces for the luck of successis in puliciy implementation, the parties must take the bulk of rosponsibility for : creating an extreme imbalance between what is normatively derircable. and what is rationally, obtainable. Both have overlouked the fact that in a system of compety tive parliamentary democracy, the enginecring of basic changes involves, a prolonged process of interest baryaining, accommodation and the réconciliation of conflicting interests. . 
Almopd, Gabriel A, and Poivell, G.B. Comparative Politics:'A Developmental Approach, Baston: Little Brown, 1966.

, and Colcman, James S. eds, The Politics of the Devoloping Areas, Princeton, Now Jersey: Princeton University, 1960 .

Amburslcy, Fitzroy, "Jamajca: From Michael Minley to Edward Seaga," in Crisis in the Caribbean, ed. Fitzroy Ambursley and Robert, Cohen, Kingston, Jamaica: Heinemann, 1983.

Aycarst, Morley, "Characteristics of West Indian Political Parties," in Aftermath of Sovereignty, ed: D. Lowenthal and L. Comitas, New York: Anchor/Doubleday, 1973.

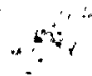

… "A Note on Somi Characteristics of west Indian Political Parties," in Social and Economic Studies, No. 3, September 1954.

Beckrord, Gcorje and Witter, Michael. Small Garden, Bitter Weed, Kingston, Jamaica: University Schoor of Printing, 1980.

- Persistent Poverty: Underdevelopment in Plantation Economias of the Third World, New York: Oxford University Press, 1972 .

Boryer, Peter L. "Can the Caribbean Learn from East Asid," Caribbean Review, Vol. XIII, No. 2, Spring,1984.

Blanchard, Paul. Democracy and Emptre in the Caripbean, New York: Macmillàn, 1947.

Butler, DiE. and Stokes, D.E. Ltectoral Chancje in Britain, London: Pelican, 2nd ed., 1971.

A Developing Worlci, map. Canaclian International Development Agency, - 1985.

Clapham, Christopher. Third World Politics, Lonłon: Croom Helm, 1985.

Domas, William, The Polttical Economy of the English-speaking Caribbean, Bridgetoim, Barbados: Cedar Press, 4th ed., 1976.

Downs, Anthony. An Economic Theory of Demōcracy, New York: Harper and . Row, 1957.

Duverger, Maurice. Political Parties: Their Organization and Activity in the Modern State, translated by Barbara and Robert North, London: Metheun, 3rd ed., 1967. 

La Palombara. Joseph, and Weiner, Myron, eds. Politicia Parties and Political Development, New Jersey, Princetor University Press, 1966.

Lacey, Terry. Violence and Politics in Jamaica, 1950-1970: Internal

- Security in a Developins Country, London: Frank Cass, 1977.

Leiserson, Avery. Parties and Politics, New'York: Alfred a, Knopf,. 1958.

Lindisy, Louis, The Myth of Independence: Middle Class Politics and Non-Mobilisation in Jamaica, U.W. I. Kingston, Jamaica:

- Institute Eor Social and Economic Rescarch, Working Paper No. 6, 1975 .

Lipset, Seymour M. "Some Social Requisites of Democracy: Econiomic Development and Political Leyitimacy," American Political Science Review, Vol. LII, March 1959.

Lowenthul, David. West'Indian Societies, Now York: Oxford University Prosis, 1972 .

Mingat, A. P. "The Difficult Path to Socialism in the English-Speaking Curibbean," in .Capitalism and State in U.S. -Latin American Relations, edo R.R. Fagen, California: Stanford University Press, . 1979.

- Malloy, Michael. Jamaica: Struggle in the Periphery, London: Writers and Readers, 1982 . - Trne Pòlitics of Change: A Jamàican Tèstament, London: Andre Doutsch, 1974.

Masur, Gerhard, "Foreign Political Ideologies in the Caribbean," in The "Caribbean: Its Political Problems, ed. A. Curtis Wilgus, Gainsville, Fla: University of Florida Press,. 1962.

- Mills, G. E. "Electoral Reform in Jamaica," Caribbeán Quarterly, Vol. 27. No: 1, March 1981.

Milne, R. S. "Decision-making in Developing Countries," Journal of Comparative Administration, Vol. 3, No. 4, February 1972.

Mumroe, Travor. "Jamaica in Turmoil," Marism Today, Vol. 25, No. 5. 1981 .

The Politics of Constitutional Decolonization: Jamaica 1944-62, U.W.I. Kingston, Jamaica: Institute of Social and Economic Rescarch, 1972.

Nettleford, Rex. Foreword, Caribbean Quarterly, Vol. 27, No' 1; March - 1981 . 


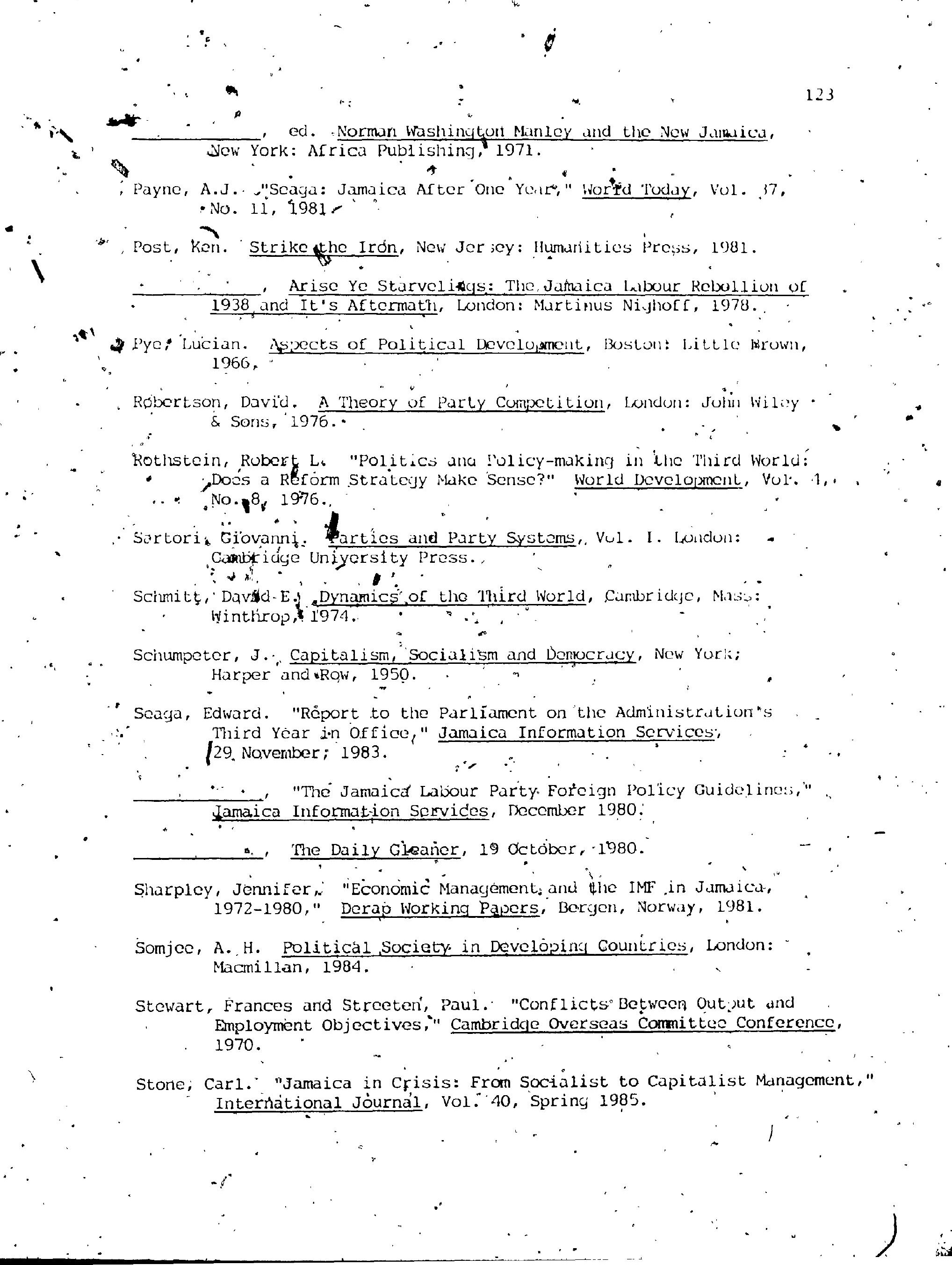


"Democracy and Socialism in Jamaica: 1972-1979," in The Newer Caribbean: Decolonization, Derrocracy and Development, ed. Paget Henry and Carl Stone, Philadelphia: Institute for the Study of Human. Issues, 1983.

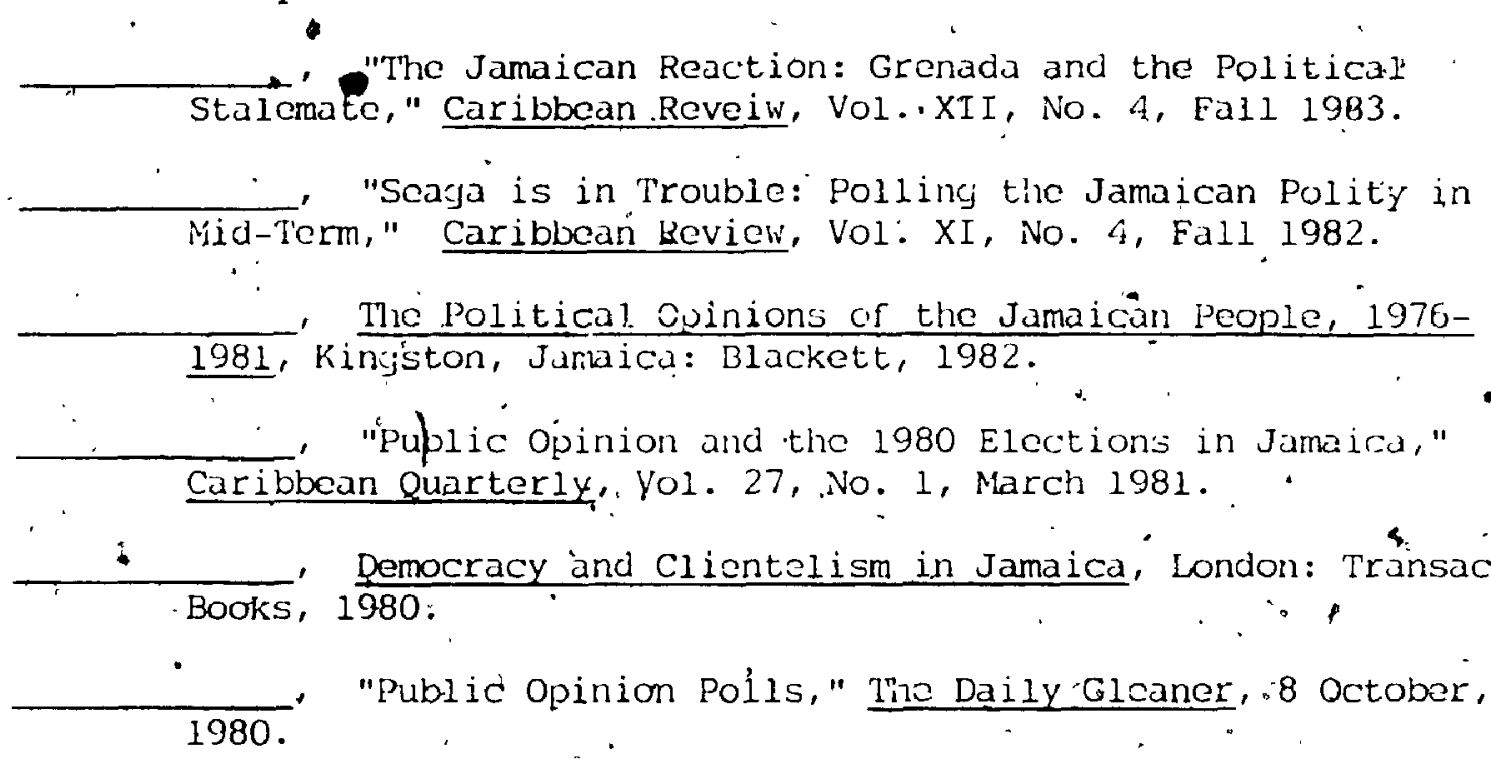

, Electoral Behavior and Public Opinion in Jamaica,

Kingston, Jamaica: Institute for Social and Economic Rescarch, 1974 .

\section{_..., "Class and tire" Institutionalization of Tro-Party Politics in Jamaica," Journal of Commonwealth and Comparative politics, Vol. XIV, No: 2, July 1976.}

'Vu Nicuweihuije, C. A. O. Development Begins at Home, Toronta: " Pergamon, 1982.

Wäters, Anita M. Race, Class anci Political Symbols, New Jersay: Transáç̣tion Boaks, 1985.

World Deveiopment Report, World Bank, 1978.

\section{JOURNALS}

American Political S̀cience Review, Vol. 65, 1971 and Vol. LII, Mäch 1959:

Caribbean quartäly, Vol.'27, No. 1, March 1981, and No. 25, September - $\$ 979$.

Caribbean Roview, Vol. XIII, No. 2, Spring 1984, Vol. XII, No. 4, Fal1 1983 and Vol. XI, No. 4; 1982.

Columbia Journaíism Revièw, March 1980. 
Development Dialogue, No. 2, 1980.

- International Jourbal, Vol. 40, Spring 1985.

Journal of Comparative Administration, vol. 3, No. 1, Fobruary 1972. Journal of CommonweaIth and Comparative Politics, Vol. XIV, No. 2, July 1976 .

Marxism Today, Vo1.'25, No.' 5, 1981.

- Social and Economic Studies, No. 3, Septomber 195.1.

Socialism, vol. 6, No. 2, 1979 and vol. 4, No. 1, 1977. "

World Devslopment, Vol.. 4, No. 8, 1976.

Norld Today, Vol. 37; No. 11, 1981.

The Daily Gleaner, Jamaica

The Daily News, Jamaica

The Financial "imes, Ner York

The Now York Times, New York

The Weekly Gleaner, Jamaica. 
